\title{
The Global Logistics Command: A Strategy to Sustain the Post-War Army
}

\author{
A Monograph \\ by \\ LTC Grant L. Morris \\ United States Army

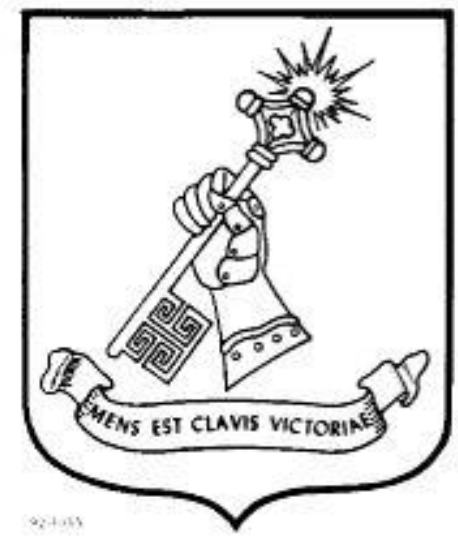 \\ School of Advanced Military Studies \\ United States Army Command and General Staff College \\ Fort Leavenworth, Kansas
}

AY 2013-2014 
Public reporting burden for this collection of information is estimated to average 1 hour per response, including the time for reviewing instructions, searching existing data sources, gathering and

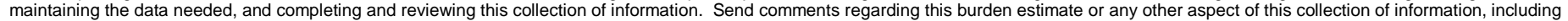

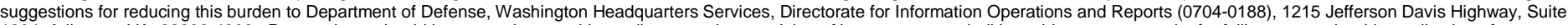
1204, Arlington, VA 22202-4302. Respondents should be aware that notwithstanding any other provision of law, no person shall be subject to any penalty for failing to comply with a collection of information if it does not display a currently valid OMB control number. PLEASE DO NOT RETURN YOUR FORM TO THE ABOVE ADDRESS.

\begin{tabular}{l|l|l}
\hline 1. REPORT DATE $(D D-M M-Y Y Y Y)$ & 2. REPORT TYPE
\end{tabular}

$\begin{array}{ll}20-05-2014 & \text { Master's Thesis }\end{array}$

4. TITLE AND SUBTITLE

THE GLOBAL LOGISTICS COMMAND: A STRATEGY TO SUSTAIN THE POSTWAR ARMY

3. DATES COVERED (From - To) Jun 2013 - May 2014 5a. CONTRACT NUMBER

5b. GRANT NUMBER

5c. PROGRAM ELEMENT NUMBER

\section{AUTHOR(S)}

Morris, Grant

5e. TASK NUMBER 5d. PROJECT NUMBER

5f. WORK UNIT NUMBER

8. PERFORMING ORGANIZATION REPORT

School of Advanced Military Studies

250 Gibbon Avenue

Fort Leavenworth, Kansas 66027-2134

\section{SS(ES)}

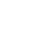

\author{
9. SPONSORING / MONITORING AGENCY NAME(S) AND ADDRESS(ES) \\ Command and General Staff College \\ 731 Mcclellan Avenue \\ Fort Leavenworth, Kansas 66027-2134
}

10. SPONSOR/MONITOR'S ACRONYM(S)

11. SPONSOR/MONITOR'S REPORT NUMBER(S)

\section{DISTRIBUTION / AVAILABILITY STATEMENT}

Approved for public release; distribution is unlimited.

\section{SUPPLEMENTARY NOTES}

\section{ABSTRACT}

Following the end of combat operations in Afghanistan and the drawdown of U.S. forces, the Army's likely future missions will consist of small-scale combat operations in increasingly remote corners of the world and humanitarian response missions in the western hemisphere. This "small-footprint" operating environment, coupled with an increasingly continentally-based Army requires a new kind of logistics mission command system with ability to deploy, employ, sustain and redeploy the full spectrum of sustainment capabilities from echelons above brigade (EAB) tactical logistics soldiers to prepositioned equipment. Additionally, this system must be capable of maintaining sufficient capabilities in the United States to provision the Army in garrison, support homeland defense, and in a humanitarian crisis, provide support to relief operations in the western hemisphere. To best support this Army, the Army of 2020 and beyond, the Department must transform the Army Materiel Command (AMC) and establish a Global Logistics Command with both an operational and strategic support capabilities. This command's smaller size and focused subordinate organizations maximize the Army's leaner logistics force structure and support the Army's reduction in operational-level headquarters.

\section{SUBJECT TERMS}

Reconstitution, Mobilization, Regeneration, Strategy, Readiness, Doctrine, Policy, Training, Materiel, Industry, Reserve Component, Force Structure, Capability, Organization

\begin{tabular}{|c|c|c|c|c|c|}
\hline \multicolumn{3}{|c|}{ 16. SECURITY CLASSIFICATION OF: } & \multirow{2}{*}{$\begin{array}{l}\text { 17. LIMITATION } \\
\text { OF ABSTRACT } \\
\text { UU }\end{array}$} & \multirow{2}{*}{$\begin{array}{l}18 . \\
\text { NUMBER } \\
53\end{array}$} & \multirow{2}{*}{$\begin{array}{l}\text { 19a. NAME OF RESPONSIBLE } \\
\text { PERSON } \\
\text { 19b. TELEPHONE NUMBER } \\
\text { (include area code) }\end{array}$} \\
\hline $\begin{array}{l}\text { a. REPORT } \\
\text { Unclassified }\end{array}$ & $\begin{array}{l}\text { b. ABSTRACT } \\
\text { Unclassified }\end{array}$ & $\begin{array}{l}\text { c. THIS PAGE } \\
\text { Unclassified }\end{array}$ & & & \\
\hline
\end{tabular}




\section{MONOGRAPH APPROVAL}

Name of

Candidate:

Monograph Title: The Global Logistics Command: A Strategy to Sustain the Post-War Army

LTC Grant L. Morris

Approved by:

, Monograph Director

Dan C. Fullerton, Ph.D. Army

\section{Approved by:}

Dan C. Fulleton, Ph.D.

G. Scott Gorman, Ph.D.

, Deputy Director, Academics, SAMS

Henry A. Arnold III, COL, IN

, Director, School of Advanced Military Studies

Accepted this 22nd day of May 2014 by:

Robert F. Baumann, Ph.D.

, Director, Graduate Degree Programs

The opinions and conclusions expressed herein are those of the student author, and do not
necessarily represent the views of the U.S. Army Command and General Staff College or any
other government agency. 


\begin{abstract}
THE GLOBAL LOGISTICS COMMAND: A STRATEGY TO SUSTAIN THE POST-WAR ARMY by LTC Grant L. Morris, United States Army, 95 pages.

Following the end of combat operations in Afghanistan and the drawdown of U.S. forces, the Army's likely future missions will consist of small-scale combat operations in increasingly remote corners of the world and humanitarian response missions in the western hemisphere. This "small-footprint" operating environment, coupled with an increasingly continentally-based Army requires a new kind of logistics mission command system with ability to deploy, employ, sustain and redeploy the full spectrum of sustainment capabilities from echelons above brigade (EAB) tactical logistics soldiers to prepositioned equipment. Additionally, this system must be capable of maintaining sufficient capabilities in the United States to provision the Army in garrison, support homeland defense, and in a humanitarian crisis, provide support to relief operations in the western hemisphere. To best support this Army, the Army of 2020 and beyond, the Department must transform the Army Materiel Command (AMC) and establish a Global Logistics Command with both an operational and strategic support capabilities. This command's smaller size and focused subordinate organizations maximize the Army's leaner logistics force structure and support the Army's reduction in operational-level headquarters.
\end{abstract}

With its operational and strategic arms, this command will be capable of supporting the total Army. Operationally, the command will transform the Army Sustainment Command (ASC), consolidate all EAB logistics headquarters, and develop the ASC into a three-star subordinate headquarters serving as the Army's Logistics Corps capable of providing C2 to all EAB logistics units (minus Contracting and Surface Deployment \& Distribution Brigades) in the Continental United States (CONUS) as well as its organic Army Field Support Brigades, Army Field Support Battalions, and Logistics Readiness Centers overseas. Enabled with the full complement of EAB logistics capabilities from pre-positioned stocks, to Logistics Civil Augmentation Program (LOGCAP) contractors, to tactical logistics soldiers, this new Logistics Corps will support everything from small-footprint missions around the globe to major regional conflicts leveraging the range of tactical to operational logistics forces. Strategically, AMC will reorganize the existing Life Cycle Management Commands (LCMC) (minus the Joint Munitions Command) into a single, strategically focused, Strategic Support Command (SSC). This strategic command will continue to develop and sustain the systems upon which soldiers rely on for lethality and survivability, but with more than just today's unity of effort. Under the SSC, when it comes to developing sustainment strategies for Army equipment, the command delivers unity of command, providing the Army with a single voice to the acquisition community and the military industrial complex. This consolidation of three two-star commands not only reduces staff redundancies, but also consolidates every arsenal and depot under one command, cutting operating costs across AMC installations. Together, the operational and strategic arms of the Global Logistics Command will create a command ready to support the Army that emerges in the post-OIF/OEF world, form the strategic- to tactical-level at every camp, post, and station around the globe. 


\section{TABLE OF CONTENTS}

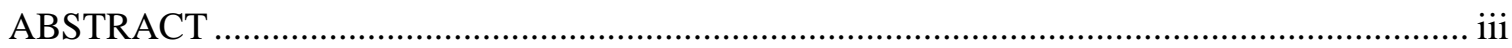

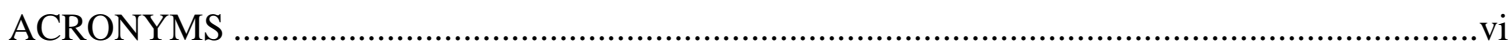

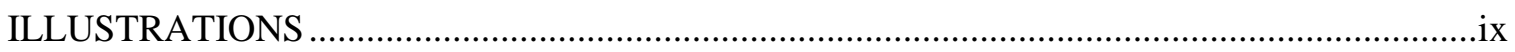

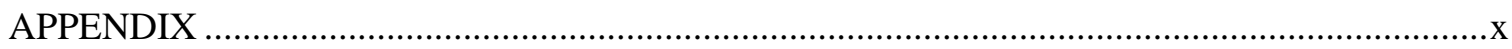

THE “GLOBAL LOGISTICS COMMAND” ........................................................................

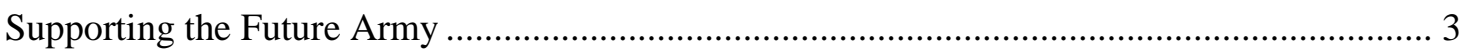

Contemporary Logistics Transformation ......................................................................... 5

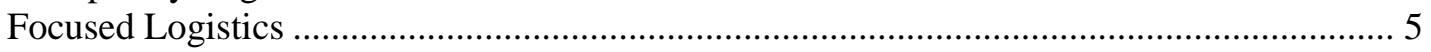

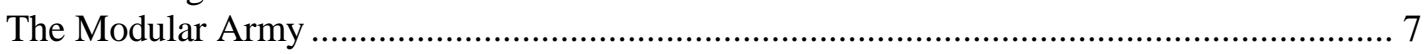

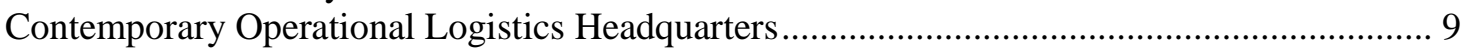

The Creation of Army Sustainment Command (ASC) ................................................... 9

Theater and Expeditionary Sustainment Commands ....................................................... 12

Globally Responsive Sustainment to the Global Logistics Command .................................... 14

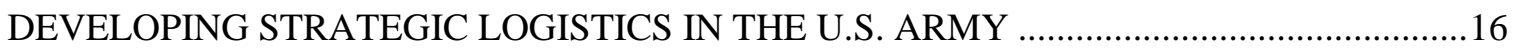

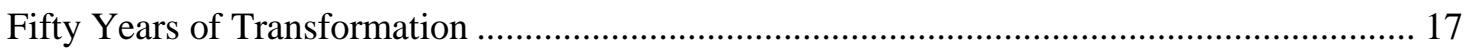

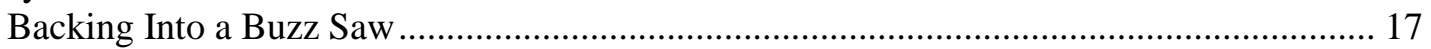

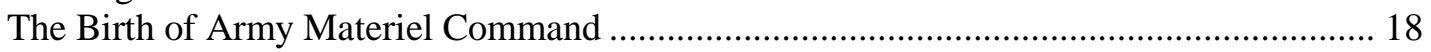

The Early Years - Vietnam .................................................................................... 20

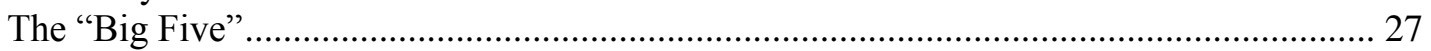

Army Sustainment Command - "The Operational Arm "................................................... 28

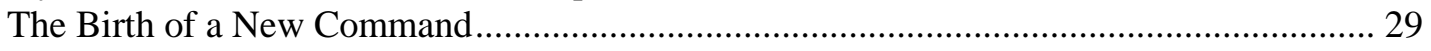

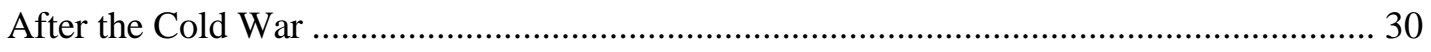

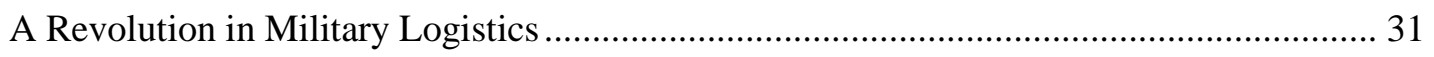

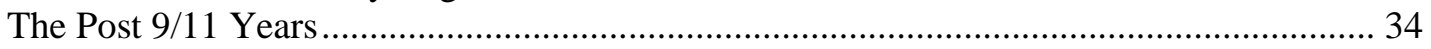

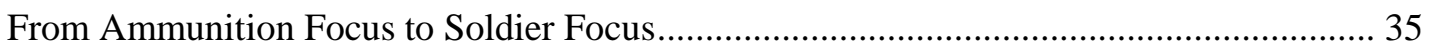

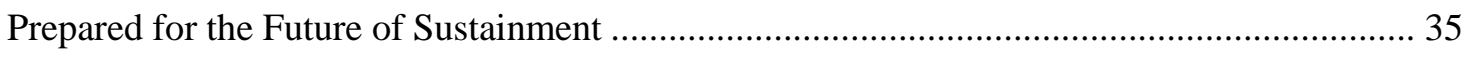

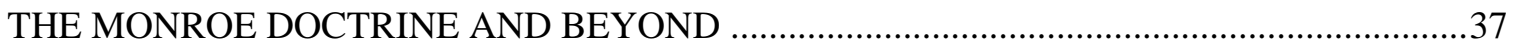

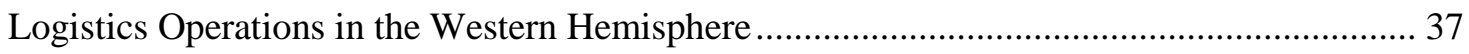

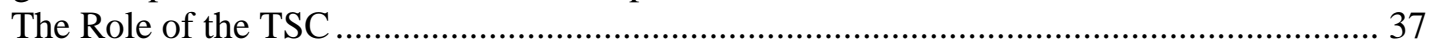

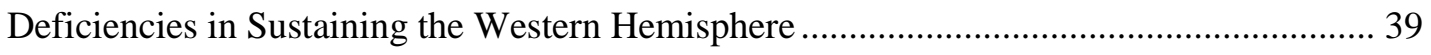

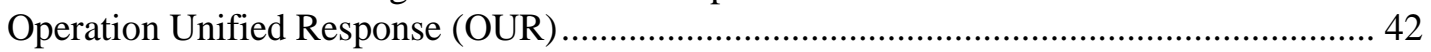

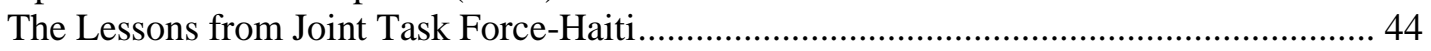

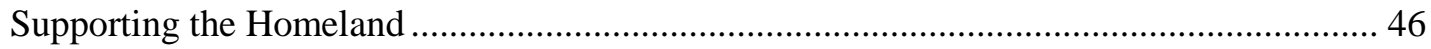

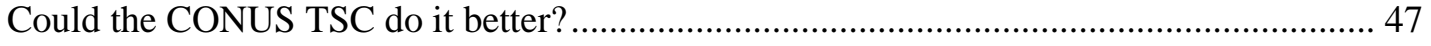

THE GLOBAL LOGISTICS COMMAND - THE ARMY'S SINGLE LOGISTICS

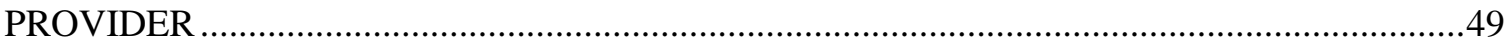


A Single Logistics Provider from the Installation to the Continent ....................................... 49

From Directorate of Logistics (DOL) to Logistics Readiness Centers (LRC)...................... 49

Leveraging Sustainment Organizations CONUS (LSOC) ............................................... 51

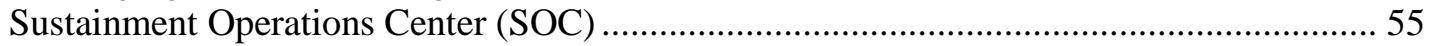

Army Sustainment Command - The Logistics Corps.......................................................... 56

Army Sustainment Command in the Global Logistics Command ....................................... 58

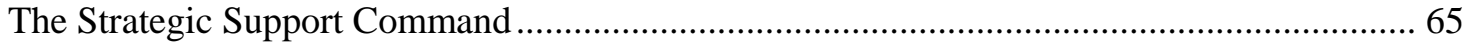

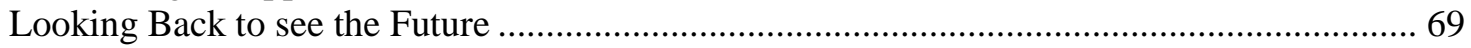

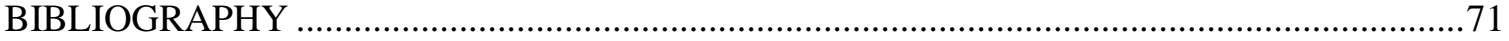

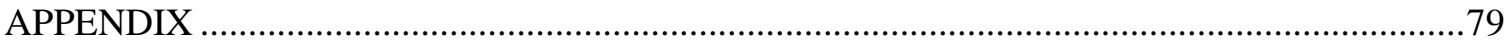




\section{ACRONYMS}

\begin{tabular}{|c|c|}
\hline AFSB & Army Field Support Brigade \\
\hline AFSC & Army Field Support Command \\
\hline AMC & Army Materiel Command \\
\hline AMCOM & Aviation and Missile Command \\
\hline AMCCOM & Army Armament, Munitions, and Chemical Command \\
\hline APS & Army Prepositioned Stocks \\
\hline ARFORGEN & Army Force Generation \\
\hline ARNORTH & U.S. Army North \\
\hline ASA $[\mathrm{ALT}]$ & Assistant Secretary of the Army for Acquisition, Logistics, and Technology \\
\hline ASC & Army Sustainment Command \\
\hline ASCC & Army Service Component Command \\
\hline AWRSPTCMI & Army War Reserve Support Command \\
\hline CASCOM & Combined Arms Support Command \\
\hline CECOM & Communications and Electronics Command \\
\hline $\mathrm{CoE}$ & Center of Excellence \\
\hline CONUS & Continental United States \\
\hline CSA & Chief of Staff of the Army \\
\hline DCSLOG & Deputy Chief of Staff for Logistics \\
\hline DMC & Distribution Management Center \\
\hline DSCA & Defense Support to Civil Authorities \\
\hline ESC & Expeditionary Sustainment Command \\
\hline FORSCOM & U.S. Army Forces Command \\
\hline FSC & Field Support Command \\
\hline HA/DR & Humanitarian Assistance/Disaster Relief \\
\hline IOC & Industrial Operations Command \\
\hline
\end{tabular}




\begin{tabular}{|c|c|}
\hline JMC & Joint Munitions Command \\
\hline JSC-A & Joint Sustainment Command - Afghanistan \\
\hline LAP & Logistics Assistance Program \\
\hline LAR & Logistics Assistance Representative \\
\hline LBE & Left Behind Equipment \\
\hline LOGCAP & Logistics Civil Augmentation Program \\
\hline LSE & Logistics Support Element \\
\hline LSOC & Leveraging Sustainment Organizations CONUS \\
\hline MAC & Munitions and Armaments Command \\
\hline MDLC & Army Materiel Development and Logistics Command \\
\hline NORTHCOM & U.S. Northern Command \\
\hline OEF & Operation Enduring Freedom \\
\hline OIF & Operation Iraqi Freedom \\
\hline ONE & Operation Noble Eagle \\
\hline OSC & Operations Support Command \\
\hline OUR & Operation Unified Response \\
\hline PEO & Program Executive Officer \\
\hline PDTE & Pre-Deployment Training Equipment \\
\hline PM & Program Manager \\
\hline $\mathrm{RCC}$ & Regional Combatant Commander \\
\hline RMA & Revolution in Military Affairs \\
\hline RML & Revolution in Military Logistics \\
\hline SB & Sustainment Brigade \\
\hline SOC & Sustainment Operations Center \\
\hline SOUTHCOM & United States Southern Command \\
\hline TACOM & Tank and Automotive Command \\
\hline
\end{tabular}




$\begin{array}{ll}\text { TRA } & \text { Training and Readiness Authority } \\ \text { TRADOC } & \text { Training and Doctrine Command } \\ \text { TRO } & \text { Training and Readiness Oversight } \\ \text { TSC } & \text { Theater Sustainment Command } \\ \text { USARAF } & \text { U.S. Army Africa } \\ \text { USAREUR } & \text { U.S. Army Europe } \\ \text { USARPAC } & \text { U.S. Army Pacific } \\ \text { USARSO } & \text { U.S. Army South } \\ \text { USASOC } & \text { U.S. Army Special Operations Command }\end{array}$




\section{ILLUSTRATIONS}

Figure 1. Notional Global Logistics Command Structure........................................................

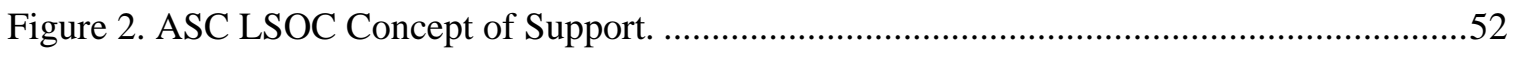

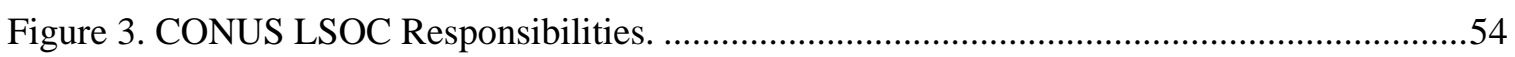

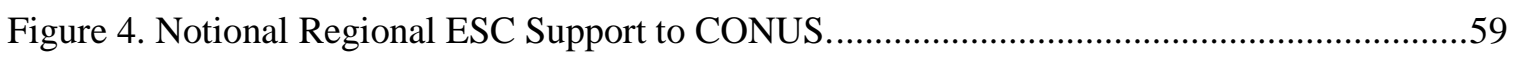

Figure 5. FEMA Regions Overlaid on ESC Regions. ..............................................................64 


\section{APPENDIX}

Appendix 1. Changes to the Army's Sustainment Force Structure Caused by the Shift to Modularity, 1984-Present.

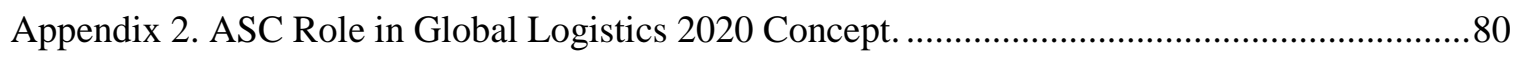

Appendix 3. Course of Action 1: Single Army Logistics Command. .........................................81

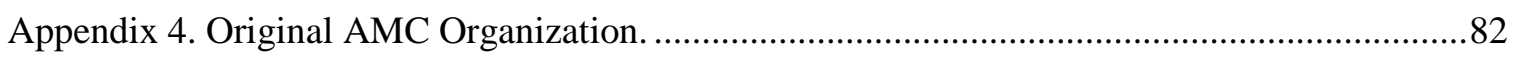

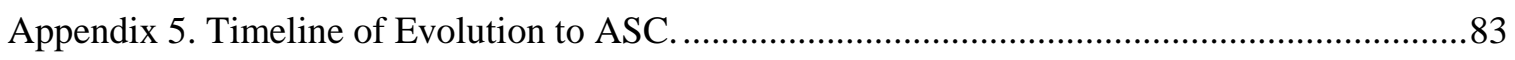

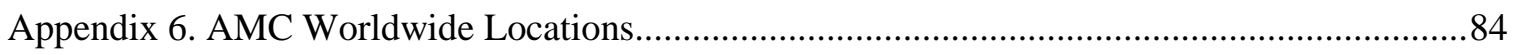

Appendix 7. Proposed Army Field Support Command (AFSC), later ASC, Headquarters Structure for Implementation in FY06, May 2003 …................................................. 85

Appendix 8. Joint Task Force-Haiti Logistics Organization, January 2010................................86

Appendix 9. Leveraging Sustainment Operations in Continental United States (LSOC)

Memorandum of Agreement between United States Forces Command and Army

Materiel Command. 
While the importance of logistics is repeatedly asserted, little has been written to indicate the complexity of the administrative machinery needed to bring the required logistic support to bear at the proper time and place, or show the difficulty of anticipating the requirements of distant battles.

- Roland G. Ruppenthal, Logistical Support of the Armies.

\section{THE “GLOBAL LOGISTICS COMMAND”}

From their earliest days, one simple principle has guided Army logisticians: provide the right support, to the right place, at the right time. Over the years, that right support has changed with the increasing sophistication and complexity of a modern Army fighting on a modern battlefield. Today, Army logisticians must continue to modernize logistics procedures, systems, and formations under the ever increasing pressures of budgetary and end-strength reduction. While the Army continues to provide a stabilizing presence around the world, the Army "will no longer be sized to conduct large-scale, prolonged stability operations" such as Operations Enduring and Iraqi Freedom. ${ }^{1}$

Following the 2014 end of combat operations in Afghanistan and the drawdown of U.S. forces, the Army's likely future missions will consist of small-scale combat operations in increasingly remote corners of the world and humanitarian response missions in the western hemisphere. Supporting these types of missions, the U.S. Army Forces Command (FORSCOM) provides both tactical logistics support, organic to its Brigade Combat Teams (BCT), and echelons above brigade (EAB) organizations such as Expeditionary Sustainment Commands (ESC), Sustainment Brigades (SB) and Combat Sustainment Support Battalions (CSSB). Likewise, the Army Sustainment Command provides EAB logistics capabilities such as Army Prepositioned Stocks (APS), Theater Provided Equipment (TPE) and the Logistics Civil

\footnotetext{
${ }^{1}$ Headquarters, Department of Defense, Sustaining U.S. Global Leadership: Priorities for 21 st Century Defense (Washington, DC: Government Printing Office, January 2012), 6.
} 
Augmentation Program (LOGCAP). ${ }^{2}$ Together, FORSCOM logistics forces and ASC support

programs provide the necessary equipment and sustainment to support with a "low-cost and small-footprint" approach similar to the support provided to Operation New Dawn in Iraq, Operation Observant Compass in Central Africa, the Combined Joint Task Force - Horn of Africa in Djibouti and military support to homeland defense. ${ }^{3}$

This "small-footprint" operating environment coupled with an increasingly continentallybased Army requires a new kind of logistics mission command mechanism. ${ }^{4}$ This new mechanism provides the ability to deploy, employ, sustain and redeploy the full spectrum of sustainment capabilities from EAB tactical logistics soldiers to prepositioned equipment while maintaining sufficient capabilities to support the Army in garrisons, supporting the homeland, and

${ }^{2}$ The Army Prepositioned Stocks (APS) program supports the National Military Strategy by strategically prepositioning vital war stocks afloat and ashore worldwide, thereby reducing the deployment response times of the modular, expeditionary Army, Association of the United States Army, "Army Prepositioned Stocks: Indispensable to America's Global Force-projection Capability," Torchbearer Issue Papers. (December 2008). http://www.ausa.org /publications/torchbearercampaign/torchbearerissuepapers /Pages/default.aspx (accessed December 5, 2013). Theater Provided Equipment (TPE) is a pool of equipment used in contingency locations as permanent stay behind equipment. TPE consists of previously deployed unit materiel, equipment issued from APS, and items purchased specifically for the operation. Using this equipment reduces the cost and time associated with deploying and redeploying unit equipment. The Logistics Civil Augmentation Program (LOGCAP) is a program consisting of standing, long-term support contacts, administered by the US Army to augment Service logistic capabilities with contracted support in both preplanned and short notice contingencies.

${ }^{3}$ Headquarters, Department of Defense, Sustaining U.S. Global Leadership: Priorities for 21 st Century Defense (Washington, DC: Government Printing Office, January 2012), www.defense.gov /news/defense_strategic_guidance.pdf (accessed July 19, 2013), 3.

${ }^{4}$ According to the October 2001 version of Army Doctrinal Publication (ADP) 3-0 Unified Land Operations, "Mission Command" is both an Army core competency and a warfighting function. As an Army core competency, Mission Command is a philosophy, "the exercise of authority and direction by the commander using mission orders to enable disciplined initiative within the commander's intent to empower agile and adaptive leaders in the conduct of unified land operations." As a warfighting function the term "Mission Command" replaces the term Command and Control and is defined as: "develops and integrates those activities enabling a commander to balance the art of command and the science of control." For the purposes of this paper, Mission Command replaces Command and Control when discussing current or future command relationships and Command and Control remains when discussing past command relationships. Headquarters, Department of the Army, ADP 3-0 Unified Land Operations. Washington, DC: Government Printing Office, October 2011. 6-13. 
in humanitarian relief operations in the western hemisphere. Acknowledging that "the sustainment system from the industrial base to the tactical level is complex and interconnected, this system must be optimized, integrated, and synchronized to ensure that it is affordable, relevant and avoids redundancy." 5 To best support the Army of 2020 and beyond, the Army must establish a Global Logistics Command under the Army Materiel Command (AMC) with both an Operational and Strategic support capability.

\section{Supporting the Future Army}

In September 2013, Army Chief of Staff, General Raymond Odierno testified before the House Armed Services Committee that the active Army would reduce its strength by fourteen percent, from a wartime high of 570,000 to 490,000 with the potential for further reductions due to discretionary spending caps. ${ }^{6}$ In order to maximize the Army's force structure under these reduction requirements, the Army will reorganize from forty-five brigade combat teams to thirtytwo and will eliminate excess headquarters infrastructure by implementing a twenty percent reduction in operational-level headquarters. ${ }^{7}$ As part of the reorganization that must occur in order to meet the requirements of a smaller Army with smaller headquarters, the Army Materiel Command must also transform. This transformation must consolidate logistics headquarters under the Army Materiel Command's four-star logistician and develop a three-star subordinate operational headquarters serving as the Army's Logistics Corps to provide C2 of all EAB

\footnotetext{
${ }^{5}$ Headquarters, Combined Arms Support Command, “Army 2020 and Beyond Sustainment White Paper” (Paper, Sustainment Center of Excellence, Ft. Lee, VA, 2013),6.

${ }^{6}$ House Armed Services Committee, Planning for Sequestration in Fiscal Year 2014 and Perspectives of The Military Services On The Strategic Choices And Management Review. 113th Cong., 1st sess., 2013, http://armedservices.house.gov/index.cfm/hearings-display?ContentRecord_id=71d1123f51f8-4141-b6e7-28d782b427fe (accessed July 21, 2013), 3.

${ }^{7}$ Ibid.
} 
logistics organizations (minus Contracting and Surface Deployment \& Distribution Brigades) in the Continental United States (CONUS) ${ }^{8}$ In addition to the development of a three-star operational headquarters, AMC must reorganize the existing Life Cycle Management Commands (LCMC) into a single command. ${ }^{9}$ By divesting their existing materiel management functions to the operational headquarters, this new headquarters emerges as a true strategically focused, life cycle maintainer, Strategic Support Command (SSC). This transformed AMC would become a true Global Logistics Command with both strategic and operational arms capable of providing strategic- to tactical-level logistics at every camp, post, and station around the globe. Some fifty years after the dismantling of the Technical Services and the establishment of Army Materiel Command, the Army is on the path to the greatest transformation of Army logistics since 1962 (See figure 1).

${ }^{8}$ Prior to the establishment of the Army Contracting Command (ACC), each command maintained individual contracting organizations. On October 31, 2007, the Army released the Report of the "Commission on Army Acquisition and Program Management in Expeditionary Operations." This report, also known as the Gansler Commission Report, came as a result of irregular contracting practices in Kuwait, Iraq and Afghanistan. Subsequent to the report's release, Army Contracting Command (ACC) became a separate command from ASC as the commission's key finding was that, "the expeditionary environment requires more trained and experienced military officers and non-commissioned officers (NCOs). Yet, only 3 percent of Army contracting personnel are active duty military and there are no longer any Army contracting career General Officer (GO) positions." With the establishment of a three-star ASC, the contracting command could be rolled up under the ASC; however, such a move requires more research to determine the feasibility. Headquarters, Department of the Army, "Urgent Reform Required: Army Expeditionary Contracting Report of the 'Commission on Army Acquisition and Program Management in Expeditionary Operations'." (Report, Department of the Army, Washington, DC, October 31, 2007), http://www.army.mil/docs/Gansler_Commission_Report_Final_071031.pdf (accessed January 21, 2014).

${ }^{9}$ AMC's Life Cycle Management Commands (LCMC): Tank and Automotive Command (TACOM), Communications and Electronics Command (CECOM), Aviation and Missile Command (AMCOM) and the Joint Munitions Command (JMC). While the author of this paper believes the LCMCs, with the exception of JMC, should merge into a Strategic Support Command (SSC), this paper does not address all the missions and functions the command should maintain or divest to the three-star ASC. 


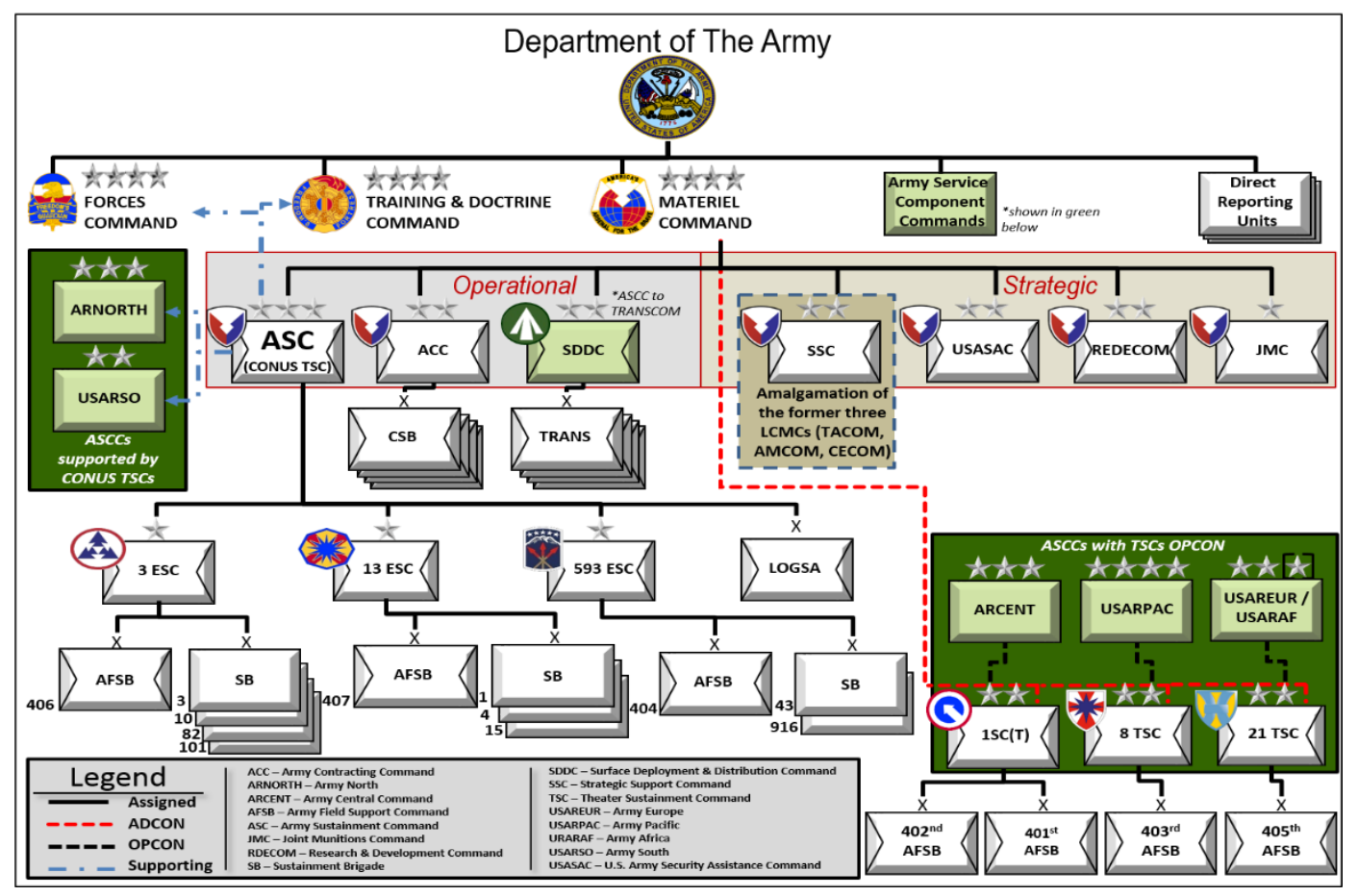

Figure 1. Notional Global Logistics Command Structure.

Source: Modified from the U.S. Army organizational chart, http://www.army. mil/info/organization/ (accessed January 21, 2014).

\section{Contemporary Logistics Transformation}

\section{Focused Logistics}

From the standpoint of Army logistics, the transformation of Army tactical and operational forces, which ended around 2007, began ten years earlier with the concept of Focused Logistics. Using the lessons learned from Operation Desert Storm and the "Iron Mountains" of 
unissued materiel, the Army looked to streamline logistics systems. ${ }^{10}$ Published in 1997, Army Vision 2010 introduced the Army to this new operational concept, which was "the fusion of information, logistics, and transportation technologies to provide rapid crisis response, to track and shift assets even while en route, and to deliver tailored logistics packages and sustainment directly at the strategic, operational, and tactical level of operations." ${ }^{11}$ Focused Logistics attempted to develop a picture of the logistics system from end to end, as an agile and adaptable logistics system built around a common situational understanding that leveraged information systems to provide visibility of assets in the pipeline, and assuring strategic communications capabilities. ${ }^{12}$ The concepts of Focused Logistics, like other transformational policies of the late 1990's promised, "that the battlefield would be increasingly transparent to U.S. forces" but, "the experience of land warfare in the post-9/11 period has frustrated nearly every aspect of the transformational approach."13

For AMC, Focused Logistics enabled the establishment of a Materiel Management Center (MMC) under the Industrial Operations Command, a predecessor of today's Army

\footnotetext{
${ }^{10}$ Operation Desert Storm was the last major conflict where the U.S. intentionally relied on a massbased logistics distribution system involving a large inventory of stocked parts and supplies. This system was necessary due to the inability of the supply pipeline to reach distant combat zones to meet demand. During Vietnam, the Army began to rely on 20-foot containers to carry and hold the large quantities of contingency stocks flowing into theater. This mass-based supply system, together with the large quantity of metal shipping containers was known as the "iron mountain." Laurel K. Myers, Ph.D., "Eliminating the Iron Mountain," Army Logistician (July-August 2004): http://www.almc.army.mil/alog/issues/JulAug04 /C_iron.html (accessed November 18, 2013). 40.

${ }^{11}$ Lieutenant Colonel Victor Maccagnan, "Logistics Transformation-Restarting a Stalled Process" (Research Paper, U.S. Army War College 2005), http://www.strategicstudiesinstitute.army.mil/pdffile s/pub593.pdf (accessed June 28, 2013), 4.

${ }^{12}$ Colonel Michael W. Snow, "Focused Logistics: Putting Agility in Agile Logistics" (Monograph, School of Advanced Military Studies, Fort Leavenworth, KS, 2011), 4.

${ }^{13}$ Thomas Donnelly and Frederick W. Kagan, Ground Truth the Future of U.S. Land Power (Washington, DC: The American Enterprise Institute for Public Policy Research, 2008), 122-124.
} 
Sustainment Command (ASC), designed to provide centralized and integrated materiel management of the Army's strategic and operational pre-positioned stocks. Under Focused Logistics, the Army envisioned tying the operational and tactical to the strategic industrial base through materiel management. Unfortunately, the Army fell short by developing a MMC only focused on APS and failed to develop vital capabilities such as integrated logistics information systems and tailorable units to maximize the capacity of a global distribution system. Today, the modular Army, enabled with more technologically advanced information systems, makes the concepts of Focused Logistics more relevant than ever; however, gaps remain between the strategic supplier (AMC) and the tactical customer. ${ }^{14}$ With the right transformation in logistics force structure and a globally focused C2 structure, these concepts are more achievable than ever.

The Modular Army

Following the concepts and creations of Focused Logistics, during his 2004 interview on Joint and Expeditionary Capabilities, Army Chief of Staff General Peter Schoomaker described the Army as "organized in 100-dollar bills, while twenties were needed," describing the ad-hoc nature of building combat support and service support capabilities to provide basic services to a maneuver battalion. ${ }^{15}$ Based on the twenty-dollar bill model, the Army began to reorganize its logistics organizations into smaller, tailorable formations. As logistics organizations modularized, Corps and Division Support Commands cased their colors along with Divisional and Corps

\footnotetext{
${ }^{14} \mathrm{AMC}$ 's primary tactical customers include the U.S. Army Forces Command (FORSCOM), Army Training and Doctrine Command (TRADOC), U.S. Army Special Operations Command (USASOC) and the five geographic Army Service Component Commands (ASCC): U.S. Army North (ARNORTH), U.S. Army South (USARSO), U.S. Army Pacific (USARPAC), U.S. Army Europe (USAREUR), U.S. Army Africa (USARAF), and U.S. Army Central (ARCENT).

${ }^{15}$ Major Cofield B. Hilburn, “Transforming for Distribution Based Logistics” (Monograph, School of Advanced Military Studies, Fort Leavenworth, KS, 2005), 1.
} 
Materiel Management Centers. Theater and Expeditionary Sustainment Commands emerged with the ability to plug into Army Service Component Commands (ASCC) to serve as the Army or Joint logistics provider in theater. In addition to the changes in the operational logistics forces, on the tactical side, former Corps Support Group organizations morphed into SBs and CSSBs, and within AMC, new structures emerged such as Army Field Support Brigades (AFSB) and Army Field Support Battalions (AFSBn). ${ }^{16}$

While these changes in the logistics landscape reduced the number and type of EAB logistics headquarters, standardized units for ease of task organization and improved the soldier's ability to reach into the Materiel Enterprise (ME), they created shortfalls throughout the FORSCOM and Army Reserve Command EAB logistics organizations. Despite the successes of modularization, the Army's "ruthless process of trimming itself and its units to meet these [General Eric Shinseki's] benchmarks; was notable for what it did not do: it did nothing to redress the shortage of sustainment and support capabilities in the active army." ${ }^{17}$ Primarily, modularization reduced the number of EAB logistics headquarters by sixteen percent, mostly at the Colonel-command level, leaving key shortfalls in C2, Training and Readiness Authority

\footnotetext{
${ }^{16}$ See Appendix 1, "Changes to the Army's Sustainment Force Structure Caused by the Shift to Modularity, 1984-Present"

${ }^{17}$ The goals laid out by General Eric Shinseki were to deploy a brigade combat team anywhere in the world in ninety-six hours, a division within 120 hours, and five divisions within thirty days. Donnelly and Kagan, Ground Truth the Future of U.S. Land Power, 123.
} 
(TRA) and Training and Readiness Oversight (TRO). ${ }^{18}$ In addition, the General Officer-level

ESCs have no habitual oversight mission over the remaining Colonel-level EAB sustainment

organizations. Without these headquarters to oversee training and readiness of logistics

organizations, there is no centralized mission command for sustainment organizations.

\section{Contemporary Operational Logistics Headquarters}

The Creation of Army Sustainment Command (ASC)

As a continuation of the logistics transformation and development towards a true Global

Logistics Command, Army Sustainment Command activated on October 1, 2006. The activation,

\footnotetext{
${ }^{18}$ Headquarters, Combined Arms Support Command, Army 2020 Tactical-Level Sustainment Support BCT and CSSB Conversions (Fort Lee, VA: Sustainment Center of Excellence, 2013), 3. Training and Readiness Authority (TRA) is defined as: The degree of Administrative Control (ADCON)/Title 10 authority that operational commanders in a unit's chain of command exercise on matters affecting the training and readiness of assigned or attached units. TRA is mission command authority (inherent with assigned command position) and specifically delegated by the commanding general. Unless specified otherwise, TRA includes the authority to give direction for leader development, organizational training, and unit readiness. A headquarters with TRA over a subordinate headquarters would provide training guidance and approve the lower headquarters training plans and mission-essential task lists, validate deploying units, and review the unit status report (USR). The TRA commander would become part of the lower headquarters rating chain, and assume all responsibilities regarding the unit's reenlistment program. Based on geographical distance between headquarters, certain responsibilities may remain with the unit's home station installation. In the areas that were specifically tasked to the TRA chain of command but required installation support or oversight, the TRA headquarters installation senior commander coordinates with the units owning installation. These responsibilities may include general court-martial convening authority, installation support, fielding of new equipment, and resources for training approved by the TRA commander. Diana M. Holland, "Strengthening the Regiment: Training and Readiness Authority-Plus," Engineer (January-April 2010), http://www.dtic.mil/dtic/tr/fulltext/u2/a560260.pdf (accessed July 21, 2013). Training and Readiness Oversight (TRO). In contrast to the training validation responsibility exercised by Army commanders (TRA), training and readiness oversight (TRO) describes the limited authority exercised by Combatant Commanders over assigned RC forces when not on active duty or when on active duty for training (ADT). Combatant Commanders normally exercise TRO through their Service Component Commanders. The TRO provides the authority to provide guidance on operational requirements and priorities to be addressed in military department training and readiness programs, approve participation by assigned RC forces in joint training, review readiness inspections of assigned RC forces, review mobilization plans (including post-mobilization training activities and deployability validation procedures) developed for assigned $\mathrm{RC}$ forces, and comment on service program recommendations and budget requests. Headquarters, Department of the Army, AR 350-1 Army Training and Leader Development (Washington, DC: Government Printing Office, August 3, 2007), 6.
} 
based on recommendations of the Institutional Army Task Force's analysis of the AMC, dated November 8, 2004, envisioned ASC as the “Army's Fourth Corps (Log)."19 The design, approved in February 2006, called for the assignment of all CONUS EAB logistics units to AMC. In addition to providing mission command for all Theater Support Commands, the command would fulfill the role of a CONUS TSC supporting Army North, Army South, Forces Command, Training \& Doctrine Command, and Special Operations Command.$^{20}$ Included in this design, and actually executed, was the growth of the now six-year-old MMC created as a result of the logistics transformation which eliminated materiel managers from the former division and corps, the majority of class VII management moved to ASC headquarters in Rock Island Arsenal, Illinois. $^{21}$

The result of the task force's analysis was Army Campaign Plan (ACP) decision point (DP) 54, TSC C2 Relationships and CONUS TSC (Army Sustainment Command), the Army's decision point for the creation of the ASC. ${ }^{22}$ The establishment of the ASC directly supported the transforming Army and facilitated a more effective response to the needs of the Geographic Combatant Commanders and ASCCs by linking the AMC's industrial base capabilities directly to the joint warfighter. While direct soldier interface was nothing new to the organization, the

\footnotetext{
${ }^{19}$ Major General Wade H. McManus, Jr., “ACP DP 54, 55 and 56 Update and CONUS TSC (Army Sustainment Command) presented to GEN Richard Cody, Vice Chief of Staff Army" (Presentation, Army Materiel Command, Alexandria VA, June 7, 2005), 3. Headquarters, Army Sustainment Command, White Paper the United States Army Sustainment Command: Sustaining Army and Joint Forces 2020 and Beyond (Rock Island, IL: Army Sustainment Command History Office, November 2012), 4.

${ }^{20}$ There are discrepancies between the briefings used as source material as to whether the TSCs were under the direct command and control of the ASC or if the ASC "supported" the TSCs. Prior to the modular force transformation, Theater Sustainment Commands were known as Theater Support Commands. Headquarters, Army Field Support Command, Evolving the AFSC as the Joint Logistics Support Command (JLSC) (Presentation, Army Sustainment Command, Rock Island, IL, May 26, 2004).

${ }^{21}$ Class VII - Major end items such as launchers, tanks, mobile machine shops, and vehicles.

${ }^{22}$ McManus, “ACP DP 54, 55 and 56 Update and CONUS TSC," 2.
} 
decision point's greatest merit was the idea that a single organization could provide C2, TRA, and materiel management from the tactical through the operational to the strategic sustainment base was of significant value to the warfighter. In describing the ASC, DP 54 stated, "Upon achieving full operational capability (FOC), ASC will be the: single Army Logistics Integrator ... end-toend distribution coordinator; $\mathrm{C} 2$ and training readiness manager of assigned forces, to include CONUS AC DCPs and Sustainment Brigades." ${ }^{23}$

The activation orders issued as AMC Permanent Order 055-1, February 24, 2006 included the following mission statement, "Provide Combat Service Support [now sustainment] capability to CONUS and OCONUS based units and to the Combatant Commands to ensure expeditionary warfighting readiness, while leveraging national logistics to sustain a transforming Army at war." The order also listed ASC's core capabilities as: providing CSS capability to Geographic Combatant Commanders (GCC), manage contingency stocks, and to provide back-up support to Homeland Defense; supporting FORSCOM in implementing Army Force Generation (ARFORGEN) by providing CONUS distribution management; managing equipment pools and sets to include the Army's Training and Deployment Equipment Sets, Army Prepositioned Stocks (APS), and Theater Provided Equipment (TPE); providing soldier support and serve as the horizontal coordinator and integrator of national sustainment capabilities through the Army Field

\footnotetext{
${ }^{23}$ The concept plan envisioned two Active Component, Deployable Command Posts under the Army Sustainment Command that could surge forward during a contingency operation and provide logistics C2 as part of a Joint Task Force. This structure would not usurp the responsibilities of the forward Theater Sustainment Command, but act on its behalf. Headquarters, Army Sustainment Command, Army Sustainment Command Initial Missions (Presentation, Army Sustainment Command, Rock Island, IL, September 2012), 2.
} 
Support Brigade (AFSB), Logistics Assistance Program (LAP) and the Contingency Contracting Office (CCO); and executing the Logistics Civil Augmentation Program (LOGCAP). ${ }^{24}$

Theater and Expeditionary Sustainment Commands

According to Army Technical Publication (ATP) 4-94 Theater Sustainment Command (TSC), the "TSC and its subordinate units are assigned to an Army Service Component Command (ASCC) supporting a Geographical Combatant Commander (GCC)." ${ }^{, 25}$ When the Army developed the TSC concept, it established five TSCs, three of which are active component (AC) and two reserve component (RC). These commands are theater-committed and not part of the Army Force Generation (ARFORGEN) pool. ${ }^{26}$ Of the Theater Sustainment Commands, the active component commands include: the $1^{\text {st }}$ Sustainment Command (Theater) supporting U.S. Army Central (ARCENT), the $8^{\text {th }}$ TSC supporting U.S. Army Pacific (USARPAC), the $21^{\text {st }}$ TSC supporting U.S. Army Europe (USAREUR); the reserve component commands are the $167^{\text {th }}$ TSC, U.S. Army National Guard, supporting U.S. Army North (ARNORTH) and the $377^{\text {th }}$ TSC, U.S. Army Reserve, supporting U.S. Army South (USARSO). The purpose for not committing the TSCs to the ARFORGEN pool was to provide the ASCCs with a dedicated operational-level

\footnotetext{
${ }^{24}$ Headquarters, Army Materiel Command, Permanent Order 055-1 (Fort Belvoir, VA: Government Printing Office, February 24, 2006). According to U.S. Army Forces Command (FORSCOM), the command responsible for managing Army force generation, ARFORGEN is defined as "the structured progression of increased unit readiness over time, resulting in recurring periods of availability of trained, ready, and cohesive units prepared for operational deployment in support of civil authorities and combatant commander requirements." Headquarters, Army Forces Command, "ARFORGEN Overview" (Presentation, U.S. Army Forces Command, Ft. Bragg, NC, July 22, 2009) http://www.marad.dot.gov/ documents/NPRN_WS_2009_Workshop_1_FSLDC_10-1_ARFORGEN_Overview.pdf (accessed January 16, 2014), 7.

${ }^{25}$ Headquarters, Department of the Army, ATP 4-94 Theater Sustainment Command (Washington, DC: Government Printing Office, June 2013), 1-1.

${ }^{26}$ The 377 TSC is part of the U.S. Army Reserve and headquartered in Belle Chasse, Louisiana. The 167 TSC is part of the Alabama National Guard and headquartered in Anniston, Alabama.
} 
logistics headquarters capable of "planning, controlling, and synchronizing operational-level Army deployment and sustainment for the ASCC, joint force commander (JFC), or multi-national joint force commander. It provides a centralized sustainment mission command structure for the ASCC; and supports all phases of operations from phase 0 to phase 5."27

As the senior logistics headquarters under the ASCC, the TSC has three operational responsibilities; theater opening, theater distribution and theater sustainment. The TSC manages materiel for all Army forces assigned or deployed within the assigned region and, as appropriate, for joint, international, and multinational forces. Theater Sustainment Command managers link with the ASCC chief logistics officer, or G4, in their areas of operations for resource prioritization. The TSC also coordinates with the AMC Field Support Brigade Commander to support national-level system and materiel requirements. In order to keep track of the daily requirements, the TSC creates and maintains the theater Logistics Common Operating Picture (LCOP), a graphic representation of the disposition of logistics forces/capabilities. The ability to maintain a logistics common operating picture not only provides the commander the ability to sustain operations of the tactical-level, but also allows managers at the operational-level to prioritize assets in order to maximize available resources.

This picture works well in overseas theaters where forward stationed TSCs provide C2 over EAB logistics forces, but in the CONUS, the $167^{\text {th }}$ TSC neither provides an LCOP to the

${ }^{27}$ ATP 4-94 Theater Sustainment Command, 2-1. The six phases to joint operations are: Shape, Deter, Seize Initiative, Dominate, Stabilize, Enable Civil Authorities. A phase can be characterized by the "focus" that is placed on it. Phases are distinct in time, space, and/or purpose from one another, but must be planned in support of each other and should represent a natural progression and subdivision of the campaign or operation. Each phase should have a set of starting conditions (that define the start of the phase) and ending conditions (that define the end of the phase). The ending conditions of one phase are the starting conditions for the next phase. Headquarters, Department of Defense, Joint Publication 5-0 Joint Operational Planning (Washington, DC: Government Printing Office, August 11, 2011), http://www.dtic.mil/doctrine/new_pubs /jp5_0.pdf (accessed July 19, 2013), III-39. 
ASCC (Army North) commander showing the disposition of U.S. Army Forces Command, U.S. Army Reserve and Army National Guard logistics assets, nor do they have the materiel management capability to "synchronize operational-level Army sustainment for the ASCC." 28 These responsibilities are divided between a myriad of organizations including Army Forces Command, Army Reserve Command, the National Guard Bureau, ASC, ARNORTH, the $167^{\text {th }}$ TSC, and others.

\section{Globally Responsive Sustainment to the Global Logistics Command}

In 2013, Major General Larry Wyche, Commander of the U.S. Army Combined Arms Support Command (CASCOM) issued the Army 2020 and Beyond Sustainment White Paper, which established a new concept in Army logistics, called Globally Responsive Sustainment. According to the white paper, Globally Responsive Sustainment "seeks to identify a range of attributes that help shape the future Sustainment Force." ${ }^{29}$ The efficacy of Globally Responsible Sustainment relies on a sustainment community capable of rapidly projecting power from the CONUS base. Calling for the ability to rapidly deploy forces, maintain the flexibility of prepositioned stocks, and retain the capabilities of rapid expeditionary basing while reducing installation operating costs, the idea of Globally Responsible Sustainment begins to codify the role of the ASC as the single logistics integrator as these missions are already within ASC's core

\footnotetext{
${ }^{28}$ Headquarters, Department of the Army, ATP 4-94 Theater Sustainment Command, 2-1.

${ }^{29}$ Headquarters, Combined Arms Support Command, “Army 2020 and Beyond Sustainment White Paper," 4.
} 
competencies. ${ }^{30}$ Unfortunately, the white paper falls short in describing how the logistics community should organize and prepare to meet the future operational environment, relies on the same myriad of support relationships the logistics community faces today, and fails to address the lack of $\mathrm{C} 2$ and TRA which hinder EAB logistics ability to organize and train for contingency operations. Looking back to the Global Logistics Concept Workshop outbrief which took place on December 7, 2012, CASCOM's first course of action was to establish AMC as "the single logistics command, executed by [a three-star] ASC" with all "TSCs, ESC, Sust Bde, AFSBs . . . assigned to AMC for training and readiness authority." ${ }^{31}$ By developing a logistics command structure that encompasses the range of EAB logistics organizations under a single headquarters, the concepts of Globally Responsible Sustainment become a reality.

${ }^{30}$ On October 1, 2012 AMC assumed management of the Directorates of Logistics (DOL) from the Installation Management Command (IMCOM) bringing the seven missions of the DOL under ASC control: Equipment Maintenance, Asset Management, Retail Supply and Central Issue Facility (CIF) support, Ammunition, Laundry and Dry Cleaning, Food Services (managing the Installation Dining Facilities (DFAC)), and Transportation (Personal Property Shipping Offices, House Hold Goods, Shipping and Receiving). General Dennis L. Via, "DOLs rebalanced as 'Logistics Readiness Centers'," The Fort Leavenworth Lamp, October 24, 2013, A2. To understand CASCOMs vision for AMC, See Appendix 2 "ASC Role in Global Logistics 2020 Concept.

${ }^{31}$ Headquarters, Combined Arms Support Command, "GLC Workshop \#2 Outbrief 1-2 Star GOSC," Global Logistics Concept Workshop (Presentation, Fort Lee, VA: Sustainment Center of Excellence, December 7, 2012), 20. The construct of course of action one is located at, Appendix 3, "Global Logistics Concept Workshop, Course of Action 1: Single Army Logistics Command." 
"What logistics does will not change, but how logistics is provided will change radically."

- Coburn \& Walker, Preparing for the Revolution in Military Logistics

\section{DEVELOPING STRATEGIC LOGISTICS IN THE U.S. ARMY}

From humble beginnings to a workforce of more than 70,000 military and civilian employees and a presence in 144 countries and nearly every state, AMC is the primary provider of materiel for the U.S. Army. ${ }^{32}$ Today, the term "factory to foxhole" is more relevant than ever before as the command oversees the development, testing, procurement and distribution of nearly everything "soldiers eat, wear, shoot, drive or fly." 33 Through AMC's arsenals, depots and ammunition plants, the command overhauls, modernizes, and upgrade major weapons systems and provides Department of Defense (DoD) conventional ammunition. In addition to the materiel life cycle management, AMC maintains the Army's Prepositioned Stocks (both on land and afloat), executes sustainment operations and life support through the Logistics Civil Augmentation Program, provides the majority of the Army's contracting, and manages the multibillion-dollar business of Foreign Military Sales (FMS).

\footnotetext{
${ }^{32}$ For a map of current AMC locations, see Appendix 6, "AMC Worldwide Locations."

${ }^{33}$ Rudi Williams. "African-American Ascends from Private to Four-Star General," American Forces Press Service, February 19, 1998, http://webcache.googleusercontent.com/search?q=cache: XrMHFziFdTEJ:www.defense.gov/News/NewsArticle.aspx\%3FID\%3D41545\&hl=en\&gl=us\&prmd=ivns \&strip=1 (accessed November 26, 2013).
} 


\section{Fifty Years of Transformation}

\section{Backing Into a Buzz Saw}

Since the earliest days of the U.S. Army, logistics were undertaken by the autonomous Technical Services, which ran their own procurement and field depots. ${ }^{34}$ While these independently functioning services worked sufficiently well in peacetime, the decision-making processes were "unnecessarily cumbersome" and during times of conflict, the army built, separate umbrella organizations apart from the Technical Services in order to synchronize the flow of logistics from the Continental United States (CONUS) to the war zone. ${ }^{35}$ The level of dysfunction between Technical Services was so acute that during the Korean Conflict, Secretary of Defense Robert Lovett wrote a letter to the president proposing reorganization. Realizing the level of effort this reorganization would require, he remarked that it would be "no more painful than backing into a buzz saw, but long overdue. ${ }^{״ 6}$ In 1954, under the direction of the Deputy Chief of Staff for Logistics (DCSLOG) the Army attempted to reform and reorganize the Technical

\footnotetext{
${ }^{34}$ Prior to 1942 as many as sixty-one agencies reported directly to the Army Chief of Staff. In March 1942, Chief of Staff, General George Marshall consolidated the Army's structure into the Army Ground Forces, Army Air Forces and the Services of Supply, which were renamed the Army Service Forces on March 12, 1943. The Army Service Forces brought together elements of the War Department General Staff, the Office of the Under Secretary of War, the eight administrative bureaus, the nine corps areas and the six supply arms and services. The six Technical Services became part of the Army Service Forces under the titles: the Corps of Engineers, Signal Corps, Ordnance Department, Quartermaster Corps, Chemical Corps, and Medical Corps. A seventh technical service, the Transportation Division, established on February 28, 1942, then renamed the Transportation Service in April 1942, and finally became a Corps July 31, 1942. Unlike the chiefs of the combat arms, neither the duties nor the structures of the technical services were altered by their becoming part of the Army Service Forces. James E. Hewes Jr., "The Marshall Reorganization," From Root to McNamara Army Organization and Administration (Washington, DC: U.S. Army Center of Military History, 1975), http://www.history.army.mil /books/root/chapter2.htm (accessed August 23, 2013), 57-103.

${ }^{35}$ Headquarters, Army Materiel Command, Arsenal for the Brave: A History of the United States Army Materiel Command 1962-1968 (Alexandria, VA: Historical Office, U.S. Army Materiel Command, September 30, 1969), 3.

${ }^{36}$ Ibid.
} 
Services from within, but, as with earlier efforts "effective integration of the supply system was not achieved, and...the Army continued to operate with seven separate supply systems." ${ }^{, 37}$ According to Russell Petcoff, author of Army Materiel Command History: 1960s, during the remainder of the post-WWII years there was a "growing uneasiness in both the executive and legislative branches of the Government over the Government's ability to manage and control its massive Defense effort, particularly in the spectacular area of research and development." 38 Petcoff further pointed out that President Eisenhower "was concerned that the United States had no formal armaments industry and could no longer 'risk its safety on emergency improvisation'." ${ }^{39}$ This concern could be seen in the President's Farewell Address on January 17, 1961, when he gave the infamous warning of the "unwarranted influence . . . by the militaryindustrial complex" leading to sweeping changes in the Kennedy administration. ${ }^{40}$

\section{The Birth of Army Materiel Command}

Under the Kennedy administration, Defense Secretary Robert McNamara championed the Army-wide logistics overhaul known as "OSD Project 80 (Army) . . study the functions,

\footnotetext{
${ }^{37}$ Headquarters, Army Materiel Command, Arsenal for the Brave, 4.
}

${ }^{38}$ Russell Petcoff, “Army Materiel Command History: 1960s," Army News Service (October 23, 2006). http://www.army.mil/article/85246/ (accessed July 13, 2013).

${ }^{39}$ Ibid.

${ }^{40}$ Dwight D. Eisenhower, The Farewell Address (Washington, DC: Eisenhower Presidential Library and Museum, January 17, 1961), http://www.eisenhower.archives.gov/research/onlinedocuments/ farewell_address.html (accessed September 25, 2013). 
organization, and procedures of the Department of the Army." 41 The primary focus of the study was to determine "how well the Department of Defense was adapting itself to the explosion in technology, to new management concepts, and to the unprecedented complexity of its missions." ${ }^{42}$ Under the direction of the Army’s Deputy Comptroller, Leonard W. Hoelscher, a group of Army officers and Department of the Army civilians began the study in April of 1961. Known as the Hoelscher Committee, its recommendations would become "the basis for one of the most sweeping reorganizations in the history of the Department of the Army."43 The key recommendation of the study was the consolidation of the Technical Services, and in 1962, the Army created a single major command charged with "developing and furnishing the Army with the weapons and tools of modern war."44 This command, the Army Materiel Command, assumed the materiel missions of six of the Army's Technical Services and became the Army's first centralized logistics command to exist in peacetime to, "reduce the complexity in administrative machinery and to gain new control of that machinery." 45

\footnotetext{
${ }^{41}$ James E. Hewes Jr., "Project 80: The Hoelscher Committee Report," From Root to McNamara Army Organization and Administration (Washington, DC: U.S. Army Center of Military History, 1975), http://www.history.army.mil/books/root/chapter9.htm (accessed August 23, 2013), 316. In addition to OSD Project 80, Secretary McNamara sponsored DOD Task Force 97. This review evaluated the quality of the Department's in-house laboratories and became a primary instrument for strengthening the in-house research laboratories and the Government's capability to manage its huge investment in research and development. Today the organization responsible for the majority of the Army's in-house research laboratories is the U.S. Army Research and Development Command (RDECOM), a major subordinate command of AMC. E. M. Glass, "Findings from Recent Studies of the Defense Laboratories by the Task 97 Action Group," (Washington, DC: Office of the Director of Defense Research and Engineering, December 7-8, 1964), www.dtic.mil/cgi-bin/GetTRDoc?AD=AD0637203 (accessed July 12, 2013), 1-9.

${ }^{42}$ Headquarters, Army Materiel Command, Arsenal for the Brave, 7.

${ }^{43}$ Russell Petcoff. "AMC Birthed from 'Sweeping Reorganization' to Outfit Today's Soldiers," Army News Service (August 16, 2012), http://www.army.mil/article/85663/ (accessed July 13, 2013).

${ }^{44}$ Headquarters, Army Materiel Command, Arsenal for the Brave, $i$.

${ }^{45}$ Ibid., ii.
} 
Officially commissioned as a Department of the Army major field command by General Order 23 effective May 8, 1962 as the U.S. Army Materiel Development and Logistics Command (MDLC), AMC and later confirmed by General Order 4 as Headquarters U.S. Army Materiel Command with an effective date of August 1, 1962. ${ }^{46}$ In order to reduce duplication and overlap, the command "brought together seven of the Army's major component commands - five of those being the commodity-type commands then known as the Weapons Command, Munitions Command, Mobility Command, Missile Command, and Electronics Command; and two functional-type commands known as the Supply and Maintenance Command, and the Test and Evaluation Command." ${ }^{\prime 7}$ In a letter to the command, Lieutenant General Frank Besson, the first commander, said of the new organization, "it is the single integrated organization specifically conceived and designed to provide the Army's weapons and equipment." 48

\section{The Early Years - Vietnam}

Perhaps the greatest challenge for the command came five months before its third birthday with President Johnson's decision to send U.S. Marines ashore in Vietnam in March 1965, followed shortly thereafter by U.S. Army ground combat units. Unlike during the Second World War, Vietnam did not have a logistician responsible for the theater logistics plan or build-

\footnotetext{
${ }^{46}$ United States of America, National Archives, "Records of the United States Army Materiel Command, Record Group 544, 1941-73," under "544.1 Administrative History," http://www.archives.gov /research/guide-fed-records/groups/544.html (accessed July 21, 2013). For the original structure of AMC, see Appendix 4, "Original AMC Organization."

${ }^{47}$ Kari Hawkins, "Army Materiel Command Grows Mission with Needs of Nation" Army News Service (August 1, 2012), http://www.army.mil/article/84767/ (accessed July 13, 2013).

${ }^{48}$ Ibid.
} 
up of supply bases. ${ }^{49}$ The lack of logistics intelligence concerning the lines of communication (LOC) and port infrastructure development hampered AMCs ability to respond to the warfighter's requirements.

In order to understand the scale of the momentous effort being undertaken, in 1963 the United States had just over 16,300 military advisors in Vietnam; by July 1965 the number jumped to 75,000 ground combat and support forces and then to 125,000 by the end of that year. The first logistics organization on the ground in Vietnam arrived on April 28, 1964, the $1^{\text {st }}$ Logistical Command from Fort Hood, Texas. Assigned responsibility "for all supply, maintenance, transportation, and services," the $1^{\text {st }}$ Logistics Command provided command and control (C2) of four subordinate commands "that operated in support of the four Corps Tactical Zones (CTZ)." ${ }^{50}$ While the $1^{\text {st }}$ Logistical Command established C2 of operational and tactical logistics in 1964, it was not until January 1966 when Lieutenant General Jean E. Engler took over as Deputy Commanding General, U.S. Army, Vietnam (USARV), that strategic logistics were considered in Vietnam. In the meantime, "Vietnam had become a logistical nightmare ... much of the time, effort, and expense involved in bringing corrective action to bear, would seem to stem directly

\footnotetext{
${ }^{49}$ In World War II, Lieutenant General John C.H. Lee General had command of the Communications Zone troops in the United Kingdom and on the Continent. In mid-January 1944, Headquarters, European Theater of Operations Untied States Army (ETOUSA), and Headquarters, Services of Supply consolidated into a single headquarters; this enlarged headquarters inherited the name of ETOUSA. While commanded by General Eisenhower, ETOUSA was controlled by Lt. Gen. Lee, deputy theater commander for supply and administration, formerly the commanding general of the Services of Supply. Forrest C. Pogue, "Command Reorganization, June-October 1944," U.S. Army in World War II: European Theater of Operations, The Supreme Command (Washington, DC: U.S. Army Center of Military History, 1954), http://www.ibiblio.org/hyperwar/USA/USA-E-Supreme/USA-E-Supreme-4.html (accessed August 23, 2013), 74.

${ }^{50}$ Lieutenant Colonel Robert J. Dixon, "Examining U.S. Army Logistics: Determining Relevance for 21st Century Operations" (Monograph, School of Advanced Military Studies, Fort Leavenworth, KS. 2012), 17.
} 
from this failure to give adequate attention to the logistical requirements of a major American buildup in Vietnam." 51

After the arrival of General Engler, the infant AMC was able to begin "the unprecedented task of simultaneously developing a logistical base and building the required levels of supply and maintenance support," however the still unclear role of U.S. forces in Vietnam led to confusion as to what type of logistics bases should be prepared, and to the AMC, "it meant that for many months there would be no firm guides as to either size or composition of the forces to be supported." 52 Despite the setbacks, AMC played a key role in the Logistics Preparation of the Battlefield.$^{53}$ Three examples of the young command's ability to support the war effort some 8,000 miles away are the so-called "DeLong piers," a project to increase deep-water seaports along the South Vietnamese coast, the introduction of "quick reaction assistance teams" and the development of the Customer Assistance Office -Vietnam (CAO-V). ${ }^{54}$

According to General William Westmoreland, commander of the United States Military Assistance Command (MACV) and the United States Army Vietnam (USARV), "There were inadequate ports and airfields, no logistics organization, and no supply, transportation, or

\footnotetext{
${ }^{51}$ Headquarters, Army Materiel Command, Arsenal for the Brave, 26.

${ }^{52}$ Rob W. Jobson and Peter M. Antell. U.S. Army Materiel Command: Essential in Peace, Indispensable in War (Tampa, FL: Faircount Publication, 2004), 23.

${ }^{53}$ Logistics Preparation of the Battlefield is the "logisticians attempt to understand the mission, the tactical plan, and time-space-distance implications for support. It is the process by which logisticians identify and assess factors that facilitate, inhibit, or deny support to the combat forces." Center for Army Lessons Learned, "Logistic Preparation of the Battlefield, September 17, 2008," under "Thesaurus," http://usacac.army.mil /cac2/call/thesaurus/toc.asp?id=33220 (accessed July 28, 2013).

${ }^{54} \mathrm{AMC}$ established Customer Assistance Offices in support of regional commanders staffed with personnel from AMC headquarters, each AMC subordinate command, and led by a Colonel at the theater headquarters. The CAO concept, approved by the AMC commanding general in November 1964, established the first office in Orleans, France on July 1, 1965. Headquarters, Army Materiel Command, "U.S. Army Materiel Command Annual Historical Review Fiscal Year 1966," Theaters Division (Alexandria, VA: Government Printing Office, 1967), 106.
} 
maintenance troops." ${ }^{55}$ In an attempt to develop the logistics infrastructure and provide the logistics specialists the theater lacked, AMC developed several programs to support the buildup of combat forces and sustain operations. The first major supporting effort from AMC was the development of prefabricated, self-elevating barge piers used in the construction of 12 deep-water ports along the coast of South Vietnam. The first two of these tug-towed piers arrived at Cam Ranh Bay in late 1965 and were operational within forty-five days. The piers doubled the throughput of the ports and increased inter-costal shipping tonnages from several hundred tons in 1965 to over three million tons by $1968 .^{56}$

Perhaps more troubling to General Westmorland was the lack of a supply systems in Vietnam. Shortly after AMC assumed the responsibilities of the Technical Services, the command began to consolidate and modernize the legacy logistics systems that previously existed. ${ }^{57}$ While the AMC was modernizing the CONUS industrial base, the logistics systems in place in Vietnam were manual, which created backlogs of supply requisitions. It was during this period that the AMC commander, General Besson, saw that many of the supply and distribution challenges of Vietnam could be solved through the introduction of "quick reaction assistance teams," or groups of Army civilian specialists prepared to deploy from CONUS on forty eight hours' notice and remain in the theater up to ninety days to provide the expertise the undersized logistics force 17.

${ }^{55}$ Dixon, "Examining U.S. Army Logistics: Determining Relevance for 21st Century Operations,"

${ }^{56}$ Jobson and Antell, U.S. Army Materiel Command, 23. Joseph M. Heiser Jr., "Supply Support in Vietnam," Vietnam Studies Logistics Support (Washington, DC: Government Printing Office, 1991), 167.

${ }^{57}$ By 1965 , the supply systems in use in the U.S. were either recently automated or still transitioning from the manual system. While soldiers trained in automated supply procedures, early in Vietnam the Army depended on non-automated logistic forces. At the time, the Army did not have the computers and technological skills to support the buildup with an automated supply system. Because the initial operations in Vietnam involved the use of a manual system, the interface between these systems, which relied heavily upon punch card operations, and the more computerized wholesale systems posed difficulties until in-country mechanization expanded. Heiser, "Supply Support in Vietnam," 37. 
lacked. ${ }^{58} \mathrm{He}$ also formalized in-theater training with two teams, codenamed Project Counter and Project Challenge. Project Counter sent supply assistance personnel to provide formal instruction in supply procedures and general warehouse operations such as location surveys, inventories, and classification; while Project Challenge, "reduced transportation and handling costs, and increased the level of control in the ordering process by requiring unit commanders to verify the priority of each requisition." 59

With the growing commitment of the U.S. in Vietnam and the growing logistics problems at the tactical-level, came logistics problems at the operational-level. At AMC headquarters, responsibility for supervision of logistics liaison visits to major commands and coordinating the referral of supply, transportation, and maintenance issues from overseas fell on the Theater Division. Because "senior logistics officers overseas lacked a clear understanding of the delineation of responsibilities among the Army Materiel Command, the Supply and Maintenance Command, and the commodity commands," in 1964 General Besson approved theater-level Customer Assistance Offices (CAO) for Europe and the Pacific. ${ }^{60}$ With the increasing logistical issues in Vietnam being addressed back at AMC headquarters, AMC established a third CAO in Vietnam in July 1965. Tasked with the mission to provide "centralized coordination of all AMC activities under the MACV," the CAO-V stood up on February 3, 1966 under Colonel Howard Ziegler. ${ }^{61}$

${ }^{58}$ Heiser, "Supply Support in Vietnam," 61.

${ }^{59}$ Major Christine D. Roney, "The Evolution of Centralized Operational Logistics” (Monograph, School of Advanced Military Studies, Fort Leavenworth, KS. 2012), 14.

${ }^{60}$ Headquarters, Army Materiel Command, "U.S. Army Materiel Command Annual Historical Review Fiscal Year 1966," 105-106.

${ }^{61}$ Ibid., 109-111. 
Over the course of the Vietnam War, it became apparent that the command played an invaluable role in developing the interface between the CONUS base and the overseas commands from the tactical to the strategic-level. From inheriting "a vast complex of installations and activities in August 1962" to building logistics infrastructure to support the American troop buildup in Vietnam, AMC was able to bring together these resources into a single Army wholesale supply organization, and assure the flow of goods and services remained uninterrupted. ${ }^{62}$ The command's early success in transitioning from a "project management" focused command to a "global sustainment organization" began in the commands infancy and carried through the expansion into the establishment of a command focused on both development and sustainment. Because of AMCs innovations during the Vietnam Era, today, AMC supports the Army's global requirements through forward field organizations such as Army Field Support Brigades and Battalions and the Logistics Assistance Program.

The Establishment of Army Development and Readiness Command (DARCOM)

According to Mr. George Eaton, Historian for the Army Sustainment Command:

The history of AMC can be described as a constant tug and pull between the R\&D and sustainment aspects of the command. In times when $R \& D$ and procurement were the focus, the command was restructured to create independent commands to conduct R\&D. When the focus was on lifecycle management, the R\&D commands were reintegrated with the sustainment commands. ${ }^{63}$

\footnotetext{
${ }^{62}$ Headquarters, Army Materiel Command, Arsenal for the Brave, 27. Another addition to the Army's ability to supply logistics on a large scale came between 1965 and 1968 when General Besson realized the utility of the 295-cubic-foot metal shipping containers used to transport and store various supplies. Knows as container express or CONEX, these shipping containers significantly curbed the supply and distribution challenges in Vietnam. By mid-1968 AMC shipped nearly 160,000 loaded CONEXes to Vietnam reaching 200,000 by the end of that year. Jobson and Antell, U.S. Army Materiel Command, 24.

${ }^{63}$ Headquarters, Army Sustainment Command, "Creation of Army Materiel Command," The ASC History News Letter 2, no. 6 (March 15, 2012), http://www.aschq.army.mil /supportingdocs /HistoryNewsMar2012.pdf (accessed November 10, 2013).
} 
Due to AMCs constant struggle between life cycle management and research and development, in 1975, the commander of AMC took the opportunity to transform AMC into an organization, which represented the balance between the sustainment and development aspects. As part of this re-organization, AMCs name changed to the Army Development and Readiness Command (DARCOM). All together, the transformation of AMC into DARCOM created sixteen subordinate commands to include five major "commodity commands" according to their principal functions for materiel readiness, six "development commands" for research and development, and five specialty commands consisting of the Test and Evaluation Command (TECOM), Mobility Equipment Research and Development Command (MERADCOM), Natick Research and Development Command (NARADCOM), Depot Systems Command (DESCOM), and the Security Assistance Command (USASAC) ${ }^{64}$ While the name only lasted until 1985 when the organization was again named AMC "to focus on the Army-wide materiel function of the command," the legacy of the 1975 reorganization can still be seen today in the current Life Cycle Management Commands (LCMC) and the research and development centers under the Research and Development Command (RDECOM). ${ }^{65}$

${ }^{64}$ Between July 1, 1976 and Jan. 3, 1978, the five commodity commands were activated under DARCOM. They were: Tank-Automotive Materiel Readiness Command (TARCOM); Armament Materiel Readiness Command (ARRCOM); Missile Materiel Readiness Command (MIRCOM); Troop Support and Aviation Materiel Readiness Command (TSARCOM); and Communications-Electronics Materiel Readiness Command (CERCOM); The six new development commands were: Tank-Automotive Research and Development Command (TARADCOM); the Armament Research and Development Command (ARRADCOM); the Missile Research and Development Command (MIRADCOM); the Aviation Research and Development Command (AVRADCOM); the Communications Research and Development Command (CORADCOM); and the Electronics Research and Development Command (ERADCOM). Jobson and Antell, U.S. Army Materiel Command, 27.

${ }^{65}$ Hawkins, "Army Materiel Command Grows Mission with Needs of Nation” 


\section{The "Big Five"}

A big part of the DARCOM legacy in the 1980s was the development and fielding of the Army's "Big Five" combat systems. The 1980s represented the height of the Cold War and during President Reagan's first term in office the world witnessed further deterioration of relations between West and East, escalation of the arms race and the 1979 Soviet occupation of Afghanistan. To solve the problem of how to fight an enemy that would maintain not only a numerical advantage in personnel, but also a numerical advantage in material, the U.S. relied on superior, cutting edge technological superiority that could defeat an enemy at ratios higher than 1:3. ${ }^{66}$ To achieve that end, in the late 1970 s work began on the "Big Five" combat systems: MIM104 Patriot (surface-to-air missile system), M1 Abrams (main battle tank), M2 Bradley (infantry and cavalry fighting vehicles), UH-60 Blackhawk (utility helicopter), and the AH-64 Apache (attack helicopter). Receiving their first real test in the 1991 liberation of Kuwait, Operation Desert Storm, the "Big Five" systems remain the mainstay of the Army's combat formations. During those years, DARCOM introduced a host of additional technologies that remain relevant in the Army's inventory today; some of those notable items include the High Mobility Multi Wheeled Vehicle (HMMWV), the Personnel Armor System for Ground Troops (PASGT) Kevlar helmet and body armor, the Battle Dress Uniform, the MK19-3 40 mm Grenade Machine Gun and the Multiple Launch Rocket System (MLRS). ${ }^{67}$

\footnotetext{
${ }^{66}$ Colonel David C. Trybula, "Big Five Lessons for Today and Tomorrow" (Research Paper, United States Army War College, 2012), http://www.benning.army.mil/Library /content/NS\%20P-4889.pdf (accessed June 28, 2013), 3.

${ }^{67}$ Kari Hawkins, “AMC-Developed Weapons Remain Vital to Army," Redstone Rocket 2012, http://www.theredstonerocket.com/tech_today/article_ca4a4998-0db3-11e2-a32a-0019bb2963f4.html ?mode=jqm (accessed September 27, 2013).
} 
During DARCOMs "Big Five" development years, corporate changes occurred within the DoD signaling more organizational change for the command. In 1986, the Goldwater-Nichols DoD Reorganization Act changed the basic structure of AMC, separating program management from life-cycle management. ${ }^{68}$ In all, AMC transferred forty-seven program managers to the Army Acquisition Executive/Program Executive Officer structure, but retained responsibility to support the project managers through matrix management. This relationship remains in place today as Army Field Support Brigades (AFSB) remain responsible for supporting the integration of Program Manager/Program Executive Officer (PM/PEO) equipment into combat formations.

\section{Army Sustainment Command - "The Operational Arm"}

With the growth of the Army's industrial base in the early 1980's, AMC realized the complexity of the command required the establishment of a major subordinate command to manage the Army's ammunition and chemical stockpile. Since inception, Army Sustainment Command, and its predecessors, missions evolved from manufacturing ammunition to serving as the singular command and control (C2) of arsenals, ammunition plants and depots to becoming the Army's Lead Materiel Integrator (LMI), ensuring soldiers have the right equipment at the

${ }^{68}$ In 1986, National Security Decision Directive (NSDD) 219 mandated the establishment of service acquisition executives charged with designating program executive offices (PEOs) that would be responsible for the oversight of acquisition programs. In essence, this change minimized the level of supervision between the program managers and their respective acquisition executives. Later that year, the Goldwater-Nichols Act codified NSDD 219 in statute, resulting in the realignment of acquisition programs under the newly formed PEOs, with Army PEOs reporting to the Assistant Secretary of the Army for Acquisition, Logistics and Technology (ASA[ALT]) in the role of Army Acquisition Executive. U.S. President. National Security Decision Directive. "Implementation of the Recommendations of the Blue Ribbon Commission on Defense Management, Decision Directive 219." http://www.fas.org/irp/ offdocs/nsdd/index.html (accessed December 4, 2013), 5. 
right time to accomplish their missions. ${ }^{69}$ Quickly growing out if its singular "munitions based" role to become AMC's operational arm, ASC is the AMC organization integrating the nation's industrial capabilities down to the BCT, through maintaining the Army's pre-positioned stocks (APS), providing the Logistics Civil Augmentation Program (LOGCAP), operating the installational Directorates of Logistics (DOL) and administering the Logistics Assistance Program (LAP).$^{70}$

\section{The Birth of a New Command}

Resulting from the merger between the U.S. Army Armament Materiel Readiness Command (ARRCOM) and the U.S. Army Armament Research and Development Command (ARRADCOM), AMC created a new major subordinate command in 1983, the U.S. Army Armament, Munitions, and Chemical Command (AMCCOM) ${ }^{71}$ Responsible for the life cycle

${ }^{69} \mathrm{ASC}$ is the major subordinate command responsible for execution of materiel integration for Army Materiel Command. According to the AMC website: AMC's designation as Lead Materiel Integrator (LMI) heralds a new method of operating the Army's materiel distribution and redistribution processes by appointing a single manager to ensure that Soldiers have the right equipment at the right time to accomplish their missions.

${ }^{70}$ The Logistics Civil Augmentation Program (LOGCAP) was established in 1985 as a method to augment uniformed Combat Service Support (CSS) capability in order to allow the Army to reduce the size of its logistics force at home station by relying on contractor support during a variety of deployed scenarios. Until 1991, when it transferred to the U.S. Army Corps of Engineers, LOGCAP was a Theater Army managed program. In 1997, AMC took over LOGCAP and in December 2001, LOGCAP transferred to Rock Island under ASC. The Logistics Assistance Program (LAP) provides early detection and resolution of logistics related problems that affect unit and materiel readiness; logistical assessments in coordination with the supported commands to identify and correct systemic problems; and support to units/soldier in garrison/home station, before, during and after deployments. Headquarters, Army Sustainment Command, "LOGCAP - Logistics Civil Augmentation Program," The ASC History News Letter 1, no. 11 (August 15, 2011), http://www.aschq.army.mil/supportingdocs/HistoryNewsAug2011.pdf (accessed August 20, 2013). The LAP program began in 1965 with the creation of Customer Assistance Offices in Korea and Europe in support of the Theater Army Commander. Headquarters, Army Sustainment Command, "Logistics Assistance Program (LAP)," The ASC History News Letter 2, no. 2 (November 15, 2011). http://www.aschq.army.mil/supportingdocs /HistoryNewsNov 2011.pdf (accessed August 20, 2013).

\footnotetext{
${ }^{71}$ For a graphical timeline, see Appendix 5, "Timeline of Evolution to ASC."
} 
management of armament and chemical materiel it became the single manager for conventional ammunition, which entailed production, management, and movement of conventional ammunition for the Department of Defense (DoD). At its inception, AMCCOM consisted of forty-seven installations and activities in twenty-six states, making it the largest subordinate command of AMC. Perhaps AMCCOM's greatest accomplishment was its support to Operations Desert Shield and Desert Storm (ODS) in 1990-1991. Beginning in August 1990, AMCCOM deployed personnel from the Materiel Management Directorate to support the movement and distribution of Class II (individual equipment), Class VII (major items), and Class IX (repair parts). By the end of the ground war on February 28, 9991, AMCCOM personnel issued a combined total of 346,600 chemical-biological protective masks and 25,741 individual and crewserved weapons. ${ }^{72}$ In addition to weapons and chemical protective equipment issued in theater, the command shipped 375,000 tons of conventional munitions and supplied over 200 AMCCOM personnel to assist combat units with ammunition management. ${ }^{73}$

\section{After the Cold War}

Following ODS and the fall of the Berlin Wall, the Army began to downsize its active force. As part of this reduction and the ongoing Base Realignment and Closure Commission (BRAC) recommendations from 1991 and 1993, AMCCOM merged with the U.S. Army Depot

\footnotetext{
${ }^{72}$ Headquarters, Army Sustainment Command, AMCCOM missions during Desert Shield/Desert Storm (1990-91) (Paper, Army Sustainment Command Historical Office, Rock Island, IL, December 20, 2013).

${ }^{73}$ At the conclusion of Operation Desert Storm, AMCCOM had shipped $\$ 97$ million worth of Class II individual equipment supplies, \$356 million worth of Class IX repair part supplies, and \$4 billion worth of Class V ammunition supplies. The command also managed the transport of 274,000 tons of artillery rounds, 34,000 tons of small arms ammo, 36,000 tons of mortar, tank, and navy gun shells, and 31,000 tons of other assorted ammunition. Headquarters, Army Sustainment Command, "Armament, Munitions, and Chemical Command - AMCCOM," The ASC History News Letter 2, no. 7 (April 15, 2012), http: //www.aschq.army.mil/supportingdocs/HistoryNewsApr2012.pdf (accessed August 20, 2012).
} 
System Command (DESCOM), another subordinate unit of AMC, to become the Industrial Operations Command (IOC) in 1994. While the command retained its conventional ammunition mission, the focus of IOC moved toward command and control of arsenals, ammunition plants, and depots, aligning all of the Army's industrial operations under one command. In addition, IOC assumed the mission to C2 the Army's War Reserve Program. ${ }^{74}$ In 1996, the commander of IOC, Major General James W. Monroe established the Army War Reserve Support Command (AWRSPTCMD) to manage prepositioned stocks, and streamlined the acquisition system. ${ }^{75}$ While the IOC continued its significant mission as the Army's organic industrial base for ammunition production and storage, the AWRSPTCMD was established as the Army's field agent responsible for the maintenance, readiness, accountability and issuing of war reserve equipment in Europe, Korea and afloat. As part of the centralization of the Army's war reserve stocks into the Army Prepositioned Stocks (APS) program, "AWRSPTCMD stood up the Materiel Management Center (MMC) designed to provide centralized and integrated materiel management of the APS brigade sets, operational projects, and sustainment stocks."76

\section{A Revolution in Military Logistics}

In order to ensure the commodity commands maintained the workload for the Army's industrial base, in 1997 IOC began transferring infrastructure to the three other commodity

\footnotetext{
${ }^{74}$ Headquarters, Army Sustainment Command, “Industrial Operations Command (IOC), " The ASC History News Letter 2, no. 8 (May 15, 2012), http://www.aschq.army.mil /supportingdocs/HistoryNews May2012.pdf (accessed August 26, 2013).

${ }^{75}$ AWRSPTCMD is the first direct predecessor of today's Army Sustainment Command; AMCCOM and later IOC are predecessors of today's Joint Munitions Command, formally established on October 1, 2006. Headquarters, U.S. Army Industrial Operations Command, A Brief History U.S. Army Industrial Operations Command (Rock Island, IL: Army Sustainment Command Historical Office, 1999), $1-2$.

${ }^{76}$ Ibid.
} 
commands reducing its real property holdings from all AMC garrisons back to the arsenals and depots supporting its ammunition mission and war reserve sites in Europe, Korea, Qatar, Kuwait and afloat.77 Following IOCs transformation away from the industrial base, AMC began another transformation after Army Chief of Staff (CSA) General Eric Shinseki announced his plan for a Revolution in Military Logistics (RML), changing the way the Army supports from "factory to foxhole."78 The AMC approach was to transform to become "the premier provider of acquisition, technology, logistics; projection and sustainment of materiel; and planning, coordinating, integration, synchronizing and controlling all logistics support above the division level for the Army."79 While planning this transformation, AMC began to recognize the importance of AWRSPTCMDs global presence, or more importantly, "this presence was at an operational level and AWRSPTCMD had established global working relationships with tactical level combat units.” As Major General Joseph W. Arbuckle noted, "With the forward presence already

${ }^{77}$ AMCs commodity commands, today known as Life Cycle Management Commands (LCMC) are Tank and Automotive Command (TACOM), Communications and Electronics Command (CECOM), Aviation and Missile Command (AMCOM) and Joint Munitions Command (JMC).

${ }^{78}$ The idea of the Revolution in Military Logistics (RML) began with former CSA General Dennis J. Reimer; he described the RML in Army Logistics Magazine in 1999 as, "This revolution is about more than providing equipment and supplies better, cheaper, and faster, although these initiatives are crucial for readiness and modernization today. It is also about rethinking logistics functions and processes that will enable decisive victories well into the future. This revolution spans the depth and breadth of military logistics - from achieving an agile defense infrastructure to getting the right stuff at the right time to the solider in the foxhole. It includes integrating logistics functions, replacing volume with velocity, reducing demand, and lightening the logistics load on the ultimate customer - the warfighter." Dennis J. Reimer, "The Revolution in Military Logistics" Army Logistics Magazine (January-February 1999), http:// www.alu.army.mil/alog/issues/JanFeb99/1999jan_feb/toc_99jf.pdf (accessed July 13, 2013).

${ }^{79}$ Headquarters, Joint Munitions Command, Armament \& Munitions Community Organizational Evolution FY73-FY10 (Presentation, Army Sustainment Command Historical Office, Rock Island, IL, 2011), 12. 
established, using the command at Rock Island as the springboard to RML was a logical choice," paving the way for AMC to designate IOC the single point of access to AMC.80

With this change in mindset from the Continental United States (CONUS) industrial base to global support of the warfighter, the name Industrial Operations Command no longer reflected the unit's mission. Under the leadership of Major General Arbuckle, on September 30, 2000 the Industrial Operations Command became Operations Support Command (OSC) with two subordinates, the Army Munitions and Armaments Command (MAC) and the Army Field Support Command (FSC). While the FSC primary mission remained the management of the APS program, under Brigadier General Jerome Johnson, FSC began to expand its mission sets to include providing command and control for all Army Materiel Command field elements, LOGCAP, and LAP. ${ }^{81}$ In describing the role of the new FSC in their work, Preparing for the Revolution in Military Logistics: The Way Ahead, Lieutenant General John G. Coburn, Army Deputy Chief of Staff for Logistics (DCSLOG) and the Honorable Robert M. Walker, Assistant Secretary of the Army for Installations, Logistics, and Environment stated:

The need for a seamless logistics organization at the national level has long been discussed. What it will look like is not yet clear, but it may be the Army's "arranger" of support, a partner of industry, effectively flattening layers and levels of support between the tactical unit or customer and the FSC. It will have total visibility of all and ownership of most, assets at all levels and be responsive to the needs of the supported force in any scenario. It will direct and control the acquisition, maintenance, and distribution of materiel and services and related logistics support from the theater commander's and

\footnotetext{
${ }^{80}$ George Eaton, "Creating AMCs Face to the Field: The US Army Sustainment Command under MG Jerome Johnson, June 2004-July 2007," (Paper, Army Sustainment Command, Rock Island, IL, July 30, 2007), 4. Headquarters, Army Sustainment Command, "Industrial Operations Command (IOC)."

${ }^{81}$ AMC field elements included AMC CONUS, AMC Forward Europe, AMC Forward Korea, the Logistics Support Elements that provided field sustainment support during times of crisis and later, AMC Forward Southwest Asia (AMC SWA), a forward deployed AMC brigadier general and staff who served as the senior AMC official to the Combined Joint Land Component Command (C/JFLCC) for Operations Enduring Freedom and Iraqi Freedom. Headquarters, Army Sustainment Command, "Field Support Command 2000-2003," The ASC History News Letter 2, no. 11 (August 15, 2012), http://www.aschq .army.mil/supportingdocs/HistoryNewsAug2012.pdf (accessed August 20, 2013).
} 
CINCs in peace and war. It provides a means to weave the current strategic, operational, and tactical levels into a seamless continuum. ${ }^{82}$

In other words, FSC, as envisioned in the late 1990s, was to be the operational level headquarters capable of integrating tactical demand with strategic supply across the Army.

\section{The Post 9/11 Years}

With the events of 9/11 and the change from a nation at peace to the Global War on Terrorism (GWOT), OSC/FSC faced the greatest test of their capabilities. While OSC focused on its missions to provide security for its eighteen installations under Operation Noble Eagle (ONE) and round the clock production, packing and shipping of ammunition in support of Operation Enduring Freedom (OEF), the FSC "began planning the shipment of various equipment from each of the overseas Army Prepositioned Stocks sites and several Continental United States locations to Southwest Asia." 83 Over the next two years, the support provided by the FSC team to the ongoing contingency operations grew to unprecedented levels and so did FSC's stature. In January of 2003, OSC became the Joint Munitions Command (JMC) and FSC was renamed the U.S. Army Field Support Command (AFSC). By July of 2003, AFSC transformed into a Major Subordinate Command of the Army Materiel Command and JMC became a subordinate unit to AFSC.

\footnotetext{
${ }^{82}$ John G. Coburn and Robert M. Walker, Preparing for the Revolution in Military Logistics (Washington, DC, 1997), 15.

${ }^{83}$ Operation Noble Eagle (ONE) is the name given to the United States and Canadian military operations related to homeland security and support to federal, state, and local agencies. The operation began September 14, 2001, in response to the September 11 attacks. Operation Noble Eagle began with the mobilization of thousands of National Guard and U.S. Army Reserve personnel to perform security missions on military installations, airports and other potential targets such as bridges, power plants, and port facilities. Headquarters, Army Sustainment Command, "Field Support Command 2000-2003."
} 


\section{From Ammunition Focus to Soldier Focus}

For the next three years, the AFSC continued to support the war both in Southwest Asia (SWA) and at home. In SWA, the Logistics Support Element (LSE) Kuwait and LSE Iraq provided C2 of all AMC equities, assisted the Program Managers and Program Executive Officers (PM/PEO) from the Assistant Secretary of the Army for Acquisition, Logistics and Technology (ASA/ALT) community with the integration of new equipment into combat formations, supported the maintenance of legacy equipment with Logistics Assistance Representatives (LAR) providing technical support directly to soldiers on the battlefield and began building the Theater Provided Equipment (TPE) sets used to reduce the cost of shipping equipment between home station and the war zone. At home station, AFSC developed PreDeployment Training Equipment (PDTE) sets at the U.S. Army Forces Command (FORSCOM) installations, established Left Behind Equipment (LBE) maintenance programs and implemented the equipment Reset induction program to quickly repair and return low-density, high-demand items. $^{84}$

\section{Prepared for the Future of Sustainment}

For the last fifty years the Army has continued to transform the agency responsible for everything "soldiers eat, wear, shoot, drive or fly." ${ }^{85}$ From its role as the primary materiel provider to its role of educating individual soldier to maintain combat systems, AMC provides indispensable services to the Army. The lessons over the past fifty years of transformation show that the consolidation of logistics enterprises brings the "factory to the foxhole" ensuring the

\footnotetext{
${ }^{84}$ The concept of AFSC becoming a three-star headquarters began in 2003 under Major General McManus. See Appendix 7, "Proposed Army Field Support Command (AFSC), later ASC, Headquarters Structure for Implementation in FY06."

${ }^{85}$ Williams, "African-American Ascends from Private to Four-Star General"
} 
unencumbered flow and availability of modern major weapons systems and conventional ammunition. For the foreseeable future, AMC will support a smaller Army based in the CONUS, conducting small scale, small-footprint missions around the globe. Since their inception, the AMC and ASC of today have proven their ability to support anywhere and at any time. A further transformed AMC into a true Global Logistics Command with both strategic and operational arms flattens the space between the soldier and the industrial base and takes the next logical step in the transformation of ASC. 
Humanitarian Assistance is a logistics problem - It's all about logistics.

- Lieutenant General P.K. (Ken) Keen, Commander, Joint Task Force - Haiti.

\section{THE MONROE DOCTRINE AND BEYOND}

Tracing back to the 1823 Monroe Doctrine with the primary objective of freeing the newly independent colonies of Latin America from European intervention, U.S. policies concerning the western hemisphere remain relatively unchanged. While the U.S. was incapable of enforcing the Monroe Doctrine at the time, over the last 190 years, the U.S. has evoked the doctrine to justify the full range of military operations from armed conflict to disaster relief. In contemporary times, U.S. intervention in the western hemisphere focuses on humanitarian assistance and disaster relief (HA/DR). This humanitarian focus, coupled with the nation's unmatched strategic reach and logistics capability guarantees U.S. military forces will continue to provide critical support during the initial stages of disasters within the hemisphere. Reiterating the nation's promise to support the hemisphere, in his 2012, Western Hemisphere Defense Policy Statement, Secretary of Defense Leon Panetta stated, "As military forces often have a unique capability to respond within life saving time requirements ... DoD will continue to promote stronger cooperation between governments and among defense institutions to respond more effectively to those humanitarian crises." $\$ 86$

\section{Logistics Operations in the Western Hemisphere \\ The Role of the TSC}

As discussed in Chapter 1, theater logistics planning from an Army perspective is the responsibility of the Army Service Component Command G4 and the Theater Sustainment Command. In the four Geographic Combatant Command areas of responsibility supported by

\footnotetext{
${ }^{86}$ Department of Defense. "Western Hemisphere Defense Policy Statement, October 2012," under "News Releases," http://www.defense.gov/news/WHDPS-English.pdf (accessed August 23, 2013). 9.
} 
active component (AC) TSCs, the TSCs retain a mature planning apparatus; maintain the ability to focus on theater-specific operational and contingency plans, and contain assigned AC logistics forces to carry out the range of military operations to include HA/DR ${ }^{87}$ In the western hemisphere, operations and planning responsibilities are divided between two Geographic Combatant Commanders, U.S. Northern Command (NORTHCOM), and U.S. Southern Command (SOUTHCOM) with capabilities and responsibilities that differ from the other combatant commands. In Northern Command, the ASCC is Army North (ARNORTH) with the $167^{\text {th }}$ TSC, Alabama Army National Guard serving as its senior logistical mission command headquarters and in Southern Command; the ASCC is U.S. Army South (USARSO) with the $377^{\text {th }}$ TSC, U.S. Army Reserve as its senior logistics headquarters. For ARNORTH, defense of the homeland is the primary responsibility and the rules governing Defense Support to Civil Authorities (DSCA) sometimes limit Title 10 USC military involvement. ${ }^{88}$ In USARSO, according to the, U.S. Army War College, Army Organization and Employment Data, the multicomponent headquarters which "consist[s] of forward stationed aviation and signal units, as well

${ }^{87} 1$ st Sustainment Command (Theater) supports U.S. Army Central (ARCENT), 8th TSC supports U.S. Army Pacific (USARPAC), and 21st TSC supports U.S. Army Europe (USAREUR) and U.S. Army Africa (USARAF).

${ }^{88}$ Title 10 USC proves the legal authorities to organize, train, and equip the U.S. Army for prompt and sustained combat, incident to operations on land. It establishes responsibility for the preparation of land forces for war and allows for the expansion of the peacetime components of the Army to meet the needs of war. Additionally, the Constitution, statutes, and policy define the role of the federal military in DSCA. According to Jeffrey Jacobs, author of CCMRF and Use of Federal Armed Forces in Civil Support Operations, "the law commonly noted as limiting the role of the federal military troops in DSCA is the Posse Comitatus Act. Posse Comitatus prohibits Title 10 forces (different from Title 32 National Guard soldiers) from enforcing state or federal laws, except as otherwise authorized by law, i.e. invocation of the Insurrection Act. Title 10 forces may not stop and frisk suspects, make arrests, conduct searches and seizures, or perform domestic surveillance. The statutory prohibition on the use of the armed forces to enforce the law, however, does not mean that the military cannot engage with and support civilian lawenforcement agencies." Jeffrey A. Jacobs, "CCMRF and Use of Federal Armed Forces in Civil Support Operations," Army Magazine (July 2009), http://usacac.army.mil/cac2/call/docs/10-16/ch_14.asp (accessed July 21, 2013). 
as Army units in GITMO," none of which are capable of robust contingency planning. ${ }^{89}$ With no permanently assigned logistics forces and a small planning capability (both in USARSO and $377^{\text {th }}$ TSC), USARSO is not positioned to execute large-scale contingency operations like their counterpart ASCCs supported by AC TSCs. When planning for Humanitarian Assistance and Disaster Relief (HA/DR) missions these organizations rely on Army Reserve and National Guard forces because the unique aspects of humanitarian relief require a large contingency of logistics organizations. Not only do these missions call for specialized forces, they require quick response to minimize human suffering making assured access to RC logistics enablers a strategic necessity. With over sixty-two percent of EAB logistics units in the RC, present policy poses a challenge to swift Army response in support of Humanitarian Relief (HR) operations. ${ }^{90}$

\section{Deficiencies in Sustaining the Western Hemisphere}

In the case of these two ASCCs responsible for conducting Army operations in the western hemisphere, their reliance on Army Reserve and National Guard TSC headquarters to plan, train and execute operational level mission command is problematic. These problems are primarily due to restrictions on the number of days USAR and ARNG soldiers can train and the degree of capability resident in RC operational structure. At the same time, the Army maintains excess AC operational-level C2 idle with the three CONUS based ESCs. Together, these problems cause both ASCCs to suffer from the ability to assemble and deploy forces to support immediate requirements following a disaster. These two shortfalls were described by logistics

\footnotetext{
${ }^{89}$ GITMO is defined as: United States Naval Station Guantanamo Bay. Headquarters, U.S. Army War College, Army Organization and Employment Data (Carlisle Barracks, PA: Center for Strategic Leadership and Development, Department of Landpower Concepts, Doctrine, and Wargaming, September 2013), 24.

${ }^{90}$ Ibid., 19.
} 
senior leaders during the Operation Unified Response after action review as, "the Army has not resourced RC sustainment capabilities requiring an accelerated deployment timeline and readiness levels to meet early entry operational requirements" and the TSCs have no habitual relationship with the CONUS based ESCs because "the Army lacks a clear role of ESC in CONUS." $" 91$

A recent example of a successful large-scale humanitarian operation planned and executed by an active component TSC is the U.S. Army Europe and $21^{\text {st }} \mathrm{TSC}$, emergency humanitarian assistance airlift to the people of Georgia in response to the Russian incursion in August 2008. Immediately following the invasion and ceasefire, "European Command, United States Army Europe, United States Air Force Europe and 21st TSC expeditiously planned and executed the initial humanitarian supply flight within 24 hours of the cease fire agreement to help bring relief to the Georgian people," a mission which could only be accomplished by a headquarters capable of changing from day-to-day operations to crisis action mode immediately. ${ }^{92}$ To contrast this very successful logistics operations in Europe with operations conducted in USARSO's area of responsibility, where the logistics planning was the responsibility of the $377^{\text {th }}$ TSC, Operation Unified Response is an excellent case study in Army's failure to resource RC organizations, especially logistics $\mathrm{C} 2$ headquarters.

\section{$\underline{\text { Under Resourced RC Sustainment Capabilities }}$}

You know in a humanitarian assistance disaster relief operation you're never gonna have time ... Turn your headquarters into a 24-hour operation planning as fast as you can plan, issuing orders as fast as you can issue orders and getting folks deployed to where they got to be. That's HA/DR. That's just the nature of the business . . . in this day and age

\footnotetext{
${ }^{91}$ Headquarters, Combined Arms Support Command, “Army 2020 and Beyond Sustainment White Paper," 32.

${ }^{92}$ Captain Bryan Woods, "21st TSC and USAFE Conduct Humanitarian Mission to Georgia," Blackanthem Military News (August 14, 2008), http://blackanthem.com/News/U_S_Military_19/21st-TSCand-USAFE-conduct-humanitarian-mission-to-Georgia18257.shtml (accessed November 13, 2013).
} 
when newspaper reporters show up on the scene and show the death and destruction to the world and everybody's waiting on the Army or the military to show up. And it's all about speed. You got the entirety of South America and Central America and a whole bunch of islands and stuff. You have probably one of the worst hurricane belts in the world. This is gonna happen again. And - and the Army component of SOUTHCOM and its TSC have got to be ready, seems to me.

- LTG Mitchell Stevenson, Army G4

Highlighting the first deficiency is the case of Operation Unified Response (OUR). The operation provided HA/DR to the people of Haiti following the devastation caused by the 2010 earthquake. According to statements made in the Department of the Army (DA) G4/Combined Arms Support Command (CASCOM) After Action Review (AAR) transcript, the $377^{\text {th }}$ TSC's logistics planning relationship with USARSO was not only under-developed prior to the earthquake, but the command was also saddled with other responsibilities to the Reserve Component. ${ }^{93}$ Some of these missions included sourcing units and individual augmentees (for Operations Iraqi and Operation Enduring Freedom) and providing TRA to a wide variety of RC (non-logistics) units. On prioritizing efforts, according to Major General Louis Visot, Commanding General of $377^{\text {th }}$ TSC during the relief effort, "we have over 40,000 soldiers that we have responsibility for," forcing the command to choose between ASCC and Reserve Command responsibilities. ${ }^{94}$ In addition to the various missions, the command executed in support of the Army Reserve, vice the ASCC, the command's multi-component structure led to shortages in key billets because they were not able to fill "their full time active component and Active Guard

${ }^{93}$ Headquarters, Combined Arms Support Command, “Operation Unified Response (OUR) Army Sustainment AAR General Officer Session 18 June 2010 Transcript of Proceedings” (Presentation, Sustainment Center of Excellence, Fort Lee, VA, 2010), 24.

${ }^{94}$ Ibid., 36. 
Reserve personnel authorizations to be able to rapidly respond to contingencies in the USARSO AOR." 95

\section{Operation Unified Response (OUR)}

On January 12, 2010 an earthquake, registering 7.0 on the Richter scale occurred at 4:53 p.m. (EST) approximately $17 \mathrm{~km}$ southwest of Port au Prince, Haiti. The U.S. government estimated that the earthquake and the aftershocks killed over 230,000 people. ${ }^{96}$ For the U.S., this disaster required immediate relief and on the following morning, President Barack Obama issued alert orders for the USS Carl Vinson, USS Bataan, USS Nassau, and USS Carter Hall, the XVIII Airborne Corps and the 2/82nd Brigade Combat Team (BCT) as the Global Response Force (GRF) to deploy to Haiti. Speaking at a White House press conference, President Obama stated:

At this moment, we are moving forward with one of the largest relief efforts in our history -- to save lives and to deliver relief that averts an even larger catastrophe. In these difficult hours, America stands united. We stand united with the people of Haiti, who have shown such incredible resilience, and we will help them to recover and to rebuild. ${ }^{97}$

\footnotetext{
${ }^{95}$ Headquarters, Combined Arms Support Command, "Operation Unified Response (OUR) Army Sustainment AAR," 66.

${ }^{96}$ According to the Haitian government the official death toll of the quake is 316,000 , a number released one year after the disaster. The 316,000 is a revision from the previously claimed and widely accepted number of 230,000. Several other numbers appear to conflict with both of the "official" death toll numbers released by the Haitian Government. The April 2010, Headquarters, XVIII Airborne Corps, United States Army, Operation Unified Response XVIII Airborne Corps Jan - Apr 2010 Initial Impressions Report places the official death toll at 217,366. In a separate report issued in October 2010 and published in the journal Medicine, Conflict and Survival, the probable death toll is estimated at 158,000 people. Adding to the confusion, in June 2011 the Associated Press released portions of an unpublished report originally commissioned by the United States Agency for International Development, which suggests the number might possibly be as low as between 46,000 and 84,000. Headquarters, XVIII Airborne Corps, "Operation Unified Response XVIII Airborne Corps Jan - Apr 2010 Initial Impressions Report” (Fort Bragg, NC: XVIII Airborne Corps History Office, 2010), $i v$.

${ }^{97}$ White House, United States of America, United States Government Haiti Earthquake Disaster Response Update 1/21/10 (Washington, DC: Government Printing Office, January 21, 2010), http://www. whitehouse.gov/the-press-office/united-states-government-haiti-earthquake-disaster-response-update-12110 (accessed September 19, 2013).
} 
This disaster prompted the longest and largest U.S. military effort in a foreign disaster relief operation, which at its peak, consisted of, "over 22,000 service members, 58 aircraft, and 23 ships" providing distribution of food, water, and medical care at sixteen sites. ${ }^{98}$ With the standdown of the Joint Task Force on June 1, 2010, OUR lasted nearly five months.

The American response to this disaster was the U.S. Agency for International Development (USAID)-led OUR where, according to the White House Press Office, the military personnel, "are playing an indispensable role in supporting this humanitarian effort, including making the logistics chain possible and distributing life-saving assistance." ${ }^{\prime 99}$ Supporting the USAID mission, the military response was a 3-star Combined/Joint Task Force (CJTF-Haiti). Under the command of the SOUTHCOM Deputy Commanding General, Lieutenant General P.K. (Ken) Keen, the JTF formed with the following mission:

Conduct Humanitarian Assistance and Disaster Relief (HA/DR) operations in support of USAID, supporting the GoH and the United Nations Stabilization Mission in Haiti (MINUSTAH) by providing localized security, targeted distribution, restoration of basic human services, medical support and critical engineering in order to alleviate human suffering and facilitate the transition of long-term recovery and reconstitution of Haiti to USAID and our international partners. ${ }^{100}$

On January 13, 2010, Joint Task Force-Haiti assumed responsibility for U.S. forces and began directing activities in support of the lead federal agency. With the XVIII Airborne Corps assault command post serving as the core of the JTF with staff plugs from Joint Forces

\footnotetext{
${ }^{98}$ Lieutenant General P.K. (Ken) Keen; Lieutenant Colonel Matthew G. Elledge; Lieutenant Colonel Charles W. Nolan; Lieutenant Colonel Jennifer L. Kimmey, "Foreign Disaster Response Joint Task Force-Haiti Observations," Military Review (November-December 2010), http://usacac.army.mil /CAC2/MilitaryReview/Archives/English/MilitaryReview_20101231_art015.pdf (accessed November 10, 2013), 86.

${ }^{99}$ Ibid.

${ }^{100}$ Headquarters, Department of the Army, "Operation Unified Response DA G-4 Army Sustainment AAR 17-18 June 2010" (Presentation, U.S. Army G-4, Washington, DC, June 2010), 8. The logistics Task Organization of JTF-Haiti is located at Appendix 8. Joint Task Force-Haiti Logistics Organization, January 2010.
} 
Command, Northern Command, European Command, Transportation Command, and other selected units mobilized personnel as augmentees, the JTF was formed in an ad hoc environment rather than from an existing Joint Manning Document (JMD). ${ }^{101}$ Early in the crisis response, the commander, SOUTHCOM, established a Joint Logistics Command (JLC) to provide the logistics common operating picture and $\mathrm{C} 2$ of logistics forces. ${ }^{102}$ According to theater apportionment, the $377^{\text {th }}$ TSC was responsible for executing the logistics operations in USARSO, but believing the $377^{\text {th }}$ was not capable of executing the mission on such a short notice, the Army instead gave the task to Colonel (Promotable) Robin Akin and the $3^{\text {rd }}$ Expeditionary Sustainment Command. ${ }^{103}$ Only later, the $377^{\text {th }}$ TSC deployed into the area of operations and conducted a relief-in-place of the $3^{\text {rd }}$ ESC to support the redeployment operations.

\section{The Lessons from Joint Task Force-Haiti}

By the time JTF Haiti stood-down in June 2010, U.S. forces and the inter-agency “provided over 4.9 million meals, 17 million pounds of bulk food, 2.6 million bottles of water". . .and "cleared over 80 blocks of debris-covered streets . . and assessed over 40,000 buildings."104 In his article Foreign Disaster Response, Joint Task Force-Haiti Observations, General P.K.

\footnotetext{
${ }^{101}$ Keen, Elledge, Nolan and Kimmey, "Foreign Disaster Response Joint Task Force-Haiti Observations," 85.

${ }^{102}$ It is not clear who made the decision to establish a joint logistics command for the operation. In the after action review conducted by the then Army G-4, Lieutenant General Stevenson, the discussion indicated that the Joint Staff encouraged Southern Command to establish a JLC. What is clear from the AAR is that neither the Southern Command commander, nor the JTF commander gave the JLC the proper manning, authorities, or C2 over both the land-centric and sea-centric forces.

${ }^{103}$ Headquarters, Combined Arms Support Command, “Operation Unified Response (OUR) Army Sustainment AAR," 25-27.

${ }^{104}$ Headquarters, United States Southern Command, “Operation Unified Response: Support to Haiti Earthquake Relief, 2010," under "Pages," http://www.southcom.mil/newsroom/Pages/OperationUnified-Response-Support-to-Haiti-Earthquake-Relief-2010.aspx (accessed December 4, 2013).
} 
(Ken) Keen graded the overall logistics response as "proactive and robust" but he underscored three challenge areas for logisticians. While two of the challenges focus on gaining an understanding of the tactical (logistics) conditions in Haiti, problems consistent with the early stages of operations in an undeveloped theater, the third challenge speaks directly to the lack of available RC resources capable of planning, training for, deploying to and operating in an expeditionary environment. General Keen stated, “[the] absence early on of a unified and integrated logistics command and control structure to integrate the overall logistics effort led to gaps in reception, staging, and movement of forces, equipment, and supplies into Haiti." 105

Because no plan existed for how USARSO and $377^{\text {th }}$ TSC would support a disaster in this region, no mechanism existed for developing a synchronized response to the disaster. This lack of synchronization, coupled with long lead times for requesting U.S. Army Reserve units left the theater without a logistics headquarters for the first three weeks of the operations. During that time, logistics planning and execution in the JTF took place within the office of the Joint Logistics Officer or J4 until the request for forces alerted the ESC; however, the organization did not begin arriving until February 19, 2010. For HA/DR, response is measured by how quickly a force arrives, orients and commences operations. For the U.S., assuring rapid response requires reliable access to both $\mathrm{AC}$ and $\mathrm{RC} \mathrm{EAB}$ logistics enablers that are trained, ready, and prepared to sustain all missions in a timely expeditionary manner. ${ }^{106}$

\footnotetext{
${ }^{105}$ Keen, Elledge, Nolan, and Kimmey, "Foreign Disaster Response Joint Task Force-Haiti Observations," 85.

${ }^{106}$ Headquarters, Department of the Army, “Operation Unified Response DA G-4 Army Sustainment AAR," 2.
} 
Supporting the Homeland

In line with General Odierno's December 2011, “Prevent, Shape, Win” speech, three missions emerge for U.S. Army North: prevent conflict through theater security cooperation operations with North American partner nations, Mexico and Canada; shape the environment through planning, training, theater sustainment and response efforts; and win by providing command and control to federal forces in support of domestic law enforcement and disaster relief agencies. ${ }^{107}$ From these missions, ARNORTH derives the responsibility to serve as the Joint Forces Land Component Command (JFLCC) to NORTHCOM. ${ }^{108}$ As the JFLCC, ARNORTH is responsible for "setting the theater" or preparing personnel and prepositioning equipment to allow for a swift military response in support of DSCA missions. As described earlier, ARNORTH's designated logistics headquarters is the 167 th Theater Support Command. The $167^{\text {th }}$ TSC's role in preventing and shaping include theater-opening tasks, such as "operating ports of debarkationair, sea and rail—and as needed build a sustainment base that allows for the maximum throughput of the federal response assets." However, relying on a National Guard sustainment command poses a significant amount of risk to a speedy response to include "statutory and funding issues that slow mobilization of reserve component units" and the potential for these units to quickly "be

${ }^{107}$ General Raymond T Odierno, "CSA Editorial: Prevent, shape, win," Army News Service (Washington, DC, December 16, 2011), http://www.army.mil/article/71030/ (accessed December 5, 2013). Association of the United States Army, "U.S. Army North/Fifth Army: Building Relationships for a Secure Homeland," Torchbearer Issue Papers December 2011, http://www.ausa.org/publications/ torchbearercampaign/torchbearerissuepapers/Pages/default.aspx (accessed December 5, 2013).

${ }^{108}$ Joint Forces Land Component Command (JFLCC) defined as: a single commander for joint land operations, which normally occurs when forces of significant size and capability of more than one Service component participate in a land operation and the Joint Force Commander (JFC) determines that doing this will achieve unity of command and effort among land forces. JFLCC has the ability to enhance synchronization of operations not only between US ground components, but with multinational land forces as well. Headquarters, Department of Defense, Joint Publication 3-31 Command and Control for Joint Land Operations (Washington, DC: Government Printing Office, June 29, 2010), http://www.dtic.mil /doctrine/new_pubs/jp3_31.pdf (accessed July 19, 2013), II-1 - II-2. 
stretched too thin in the event of a large-scale or multiple-crisis scenario before additional forces can arrive."109

\section{Could the CONUS TSC do it better?}

Both ARNORTH and USARSO are economy-of-force organizations, in terms of manpower and resources. With relatively few assigned forces, these commands must rely on planning and preparation to ensure rapid response capabilities. While "the stakes in the homeland are higher than in any other theater ... there is a potential mismatch between resources and mission that places strategic risk on the American populace at large." ${ }^{110}$ To mitigate that risk, Logistics Preparation of the Battlefield by a dedicated planning staff, such as a three-star TSC with CONUS-based, regionally-aligned ESCs is a necessity. Moreover, throughout the western hemisphere, U.S. based units provide the majority of U.S. military capability, and in disaster response, those forces must be available on short notice. Unlike many of the Reserve and National Guard units, Active Component units not in the deployment cycle can be on a short notice recall to react quickly should the president require federal forces to intervene. For support to the western hemisphere, the ASC and regionally-focused ESCs could easily provide the ASCCs ready and responsive logistics support from expeditionary capable C2 headquarters to specialized logistics and transportation units. In 2004, AMC envisioned a headquarters capable of sustaining just such missions:

Future joint and expeditionary support provided from CONUS requires the formation of a support element, structure, or organization; analogous to a TSC. The FSC with its residence (sic) competencies is postured to accommodate the mission of a CONUS TSC

\footnotetext{
${ }^{109}$ Association of the United States Army, "U.S. Army North/Fifth Army: Building Relationships for a Secure Homeland."

${ }^{110}$ Ibid.
} 
and to address the logistics needs of NORTHCOM/HOMELAND DEFENSE, SOUTHCOM, FORSCOM, TRADOC, USASOC, and other federal agencies. ${ }^{111}$

The CONUS TSC supporting logistics operations in the western hemisphere addresses

expeditionary force requirements, links forces to the sustaining base, and supports the needs of two important and under-resourced theaters. ${ }^{112}$

${ }^{111}$ Headquarters, Army Field Support Command, Evolving the AFSC as the Joint Logistics Support Command, 1.

${ }^{112}$ Ibid., 2. 
THE GLOBAL LOGISTICS COMMAND - THE ARMY'S SINGLE LOGISTICS PROVIDER

\section{$\underline{\text { A Single Logistics Provider from the Installation to the Continent }}$}

Since the founding of the Army, logisticians have struggled with delivering the right support, to the right place, at the right time. In the early days, the autonomous Technical Services carried out strategic to tactical logistics working in opposition rather than in harmony. Fifty years ago, that right support took a dramatic new direction with the development of the AMC, delivering magnificently from Vietnam to Enduring Freedom. Today, new requirements emerge calling for a smaller, CONUS-based Army capable of supporting small-footprint deployments in remote regions while maintaining the ability to deploy a deterrence force rapidly, act decisively and sustain itself across the globe. In order to meet these requirements, CONUS EAB logistics organizations must integrate into a single, formal $\mathrm{C} 2$ structure operating under regionally focused ESCs, vice the current policy of informal partnerships and memorandums of agreement.

From Directorate of Logistics (DOL) to Logistics Readiness Centers (LRC)

On October 1, 2012, AMC assumed management of the Directorates of Logistics (DOL) from the Installation Management Command (IMCOM). This acquisition of seventy three DOL locations (forty-nine in CONUS and twenty-four overseas) added some 100 soldiers, 5,000 civilians, and 18,000 contractors to the command and aligned those installation maintenance and 
supply functions under the Materiel Enterprise. ${ }^{113}$ In addition to aligning core competencies, the ownership of the Army's DOLs gives AMC and ASC a "face" on every Army installation allowing for the standardization and right sizing of DOL contracts and capabilities.

Regardless of location, each installation DOL provides all or some of the following garrison service support: Maintenance, Asset Management, Retail Supply and Central Issue Facility (CIF) support, Ammunition, Laundry and Dry Cleaning, Food Services (managing the Installation Dining Facilities (DFAC)), and Transportation (Personal Property Shipping Offices, House Hold Goods, Shipping and Receiving). When adding the menu of installation DOL support missions with other AMC tasks, such as ARFORGEN support, Reset, and managing each installation's Pre-deployment Training Equipment set, support to the BCT/Multifunctional Brigade can be a "one stop shop" experience; however, FORSCOM retains ownership of many of the sustainment organizations that fall outside of the BCT and provide support on installations. ${ }^{114}$ Further strengthening the link between the DOL and the operational Army, in October 2013, General Dennis Via, the Commanding General of AMC, announced that each of the seventy-three

\footnotetext{
${ }^{113}$ Headquarters, Department of the Army, "Army Materiel Command welcomes Directorates of Logistics," Army News Service October 24, 2012, http://www.army.mil/article/ 89844/ (accessed October 3, 2013). The Materiel Enterprise (ME) is one of the Army's four core enterprises and is responsible for materiel management from concept to combat. The ME brings together all of the organizations and stakeholders involved in providing materiel solutions for our Soldiers. It incorporates all the materiel life cycle functions to include research, development, acquisition, testing, distribution, supply, maintenance, industrial base operations, and disposal. The goal is to provide Army leadership with information and analysis to enable them to make sound decisions. Headquarters, Department of the Army, "The Materiel Enterprise: Materiel Solutions for our Soldiers," Army News Service November 2, 2009, http://www .army.mil/article/29721/The_Materiel_Enterprise__Materiel_solutions_for_our_Soldiers/ (accessed October 3, 2013).

114"Reset" is a generic term that represents a series of actions taken to restore units to a desired level of combat capability commensurate with mission requirements and available resources. At the installation level, the Directorate of Logistics normally repairs or Resets unit equipment to correct equipment faults that are above the field level. Major General William M. Lenaers and Major Brent D. Coryell, "Reset: Extending the Life of Army Equipment," Army Logistician (January-February 2006), http://www.almc.army.mil/alog/issues /JanFeb06/reset_armyeq.html (accessed November 18, 2013).
} 
DOLs would change their name to Logistics Readiness Center (LRC). According to General Via, the name change "more accurately reflects their mission under AMC, and provides a conceptual framework to reshape LRCs as AMC's 'Face to the Field'."115

\section{Leveraging Sustainment Organizations CONUS (LSOC)}

As the Army moves forward to the Global Logistics Concept and a single, echelons above brigade (EAB) logistics provider, AMC and FORSCOM took the critical first step in consolidation of logistics efforts. Called Leveraging Sustainment Organizations CONUS (LSOC), the agreed intent is "to build upon the already strong relationships between the Expeditionary Sustainment Commands (ESC), the Sustainment Brigades (SB), the Army Sustainment Command (ASC), and the Army Field Support Brigades (AFSB), all in support of the senior commander and his/her Army force generation (ARFORGEN) mission." ${ }^{116}$ In essence, the memorandum of agreement allows ASC to serve as FORSCOM's materiel manager and “translates the FORSCOM Commander's operational priorities into continental United States sustainment support." ${ }^{117}$ As depicted in Figure 2, a slide presented by the ASC to the Association of the United States Army, the ASCs "support concept" (in the blue box on the right-hand side) highlights the key functions of ASCs materiel management of FORSCOM assets and the LRC's

${ }^{115}$ Via, "DOLs rebalanced as 'Logistics Readiness Centers'," A2.

${ }^{116}$ Expeditionary Sustainment Commands (ESC) and Sustainment Brigades (SB) are both U.S. Army Forces Command (FORSCOM) units; however, there is no formal C2 relationship between them. According to the LSOC MOA, "The Expeditionary Sustainment Command (ESC) provided technical and functional support/oversight to sustainment brigades (SB)." Headquarters, Army Materiel Command, and Headquarters, Army Forces Command, "Leveraging Sustainment Organizations within the Continental United States, Memorandum of Agreement between United States Army Forces Command and Army Materiel Command" (May 20, 2011), 5.

${ }^{117}$ Headquarters, Army Field Support Battalion - Hood, 407th Army Field Support Brigade. "Army Field Support Battalion Provides Sustainment Services to Fort Hood Units." The Mighty407th (Fall 2011), under "News," http://www.osc.army.mil/supportingdocs/FINAL_Mighty407th_F2011_WEB.pdf. (accessed July 12, 2013). 16-17. 
(shown as DOL on the slide) ability to bring the power of the industrial base into the installation as the "storefront" for installation support. This FORSCOM-wide materiel management responsibility not only tasks ASC to facilitate synchronization and integration of EAB sustainment organizations, such as ESCs and SBs, it establishes a precedent for ASC to become FORSCOMs logistics provider in a C2 role. ${ }^{118}$

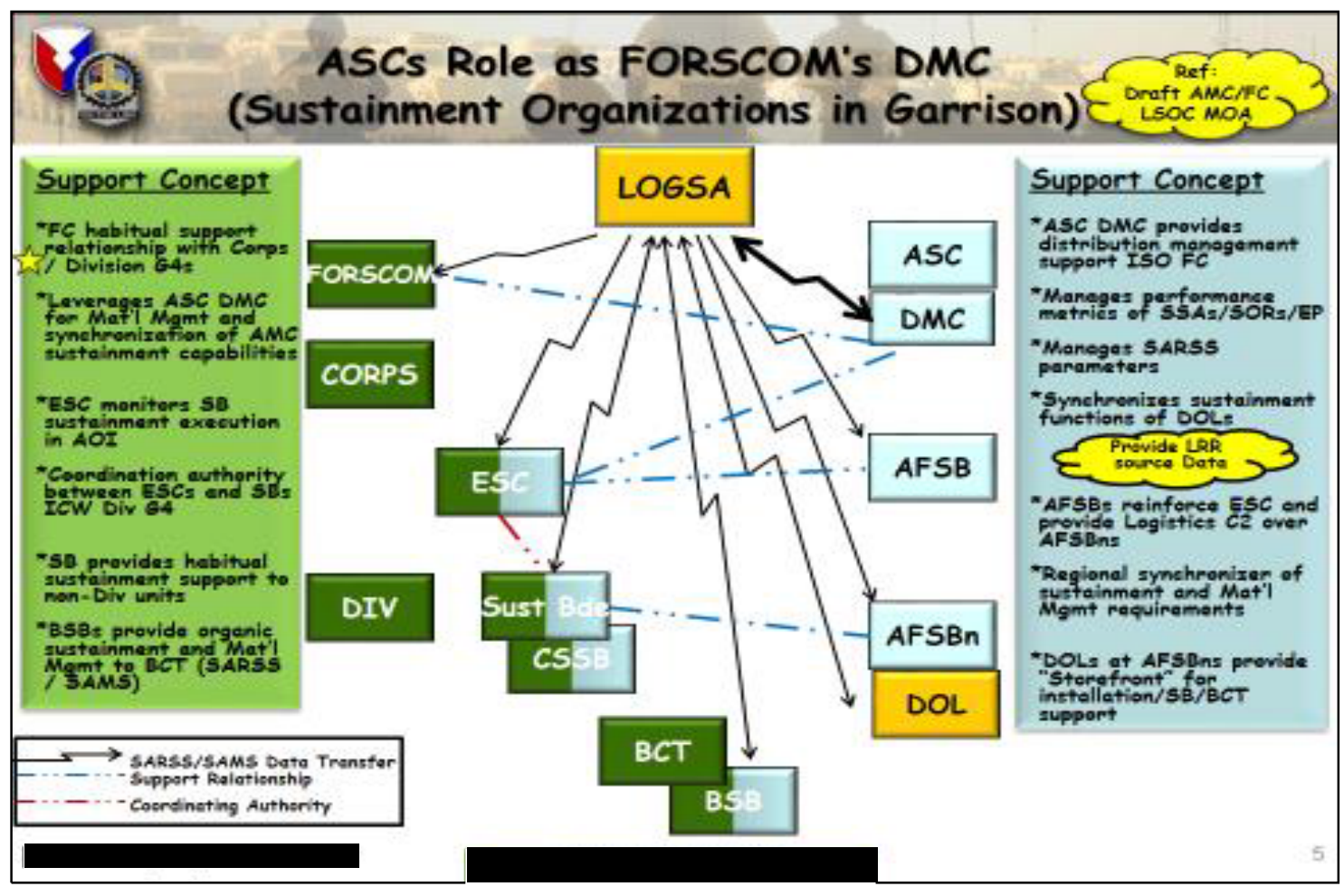

Figure 2. ASC LSOC Concept of Support.

Source: Headquarters, Army Sustainment Command. AUSA Sustainment Symposium: LSOC Panel, Rock Island Arsenal, IL, May 2011, 5.

${ }^{118}$ The complete LSOC memorandum is located at Appendix 9. 
Several examples of LSOC in action took place on Fort Hood where the $13^{\text {th }}$ ESC and $4^{\text {th }}$ SB are located. Supporting the re-stationing of the 4th Combat Aviation Brigade from Fort Hood to Fort Bliss, Texas, FORSCOM and AMC developed a concept of support that provided soldiers from the 4th SB to transport the unit's equipment between the two Army forts. Prior to LSOC, the moving unit would have relied on commercial contract carriers to line-haul their equipment the 590 miles between the forts. This joint effort not only reduced transportation cost by $\$ 500,000$, but also provided soldiers functional training enhancing their specialty skills. Another example on Fort Hood was the hand-off of operational control of the ammunition supply point to the 664th Ordnance Company, a job normally handled by contract employees of the DOL. ${ }^{119}$ These and other missions previously conducted by contracted workers on Fort Hood saved the Army an estimated $\$ 9$ million over the fiscal year. ${ }^{120}$

The memorandum also highlighted that, while there is no formal C2 arrangement between ESCs and SBs, the ESCs now provide technical and functional support/oversight to SBs on a regional basis as depicted in figure $3 .{ }^{121}$ The ESC assists the FORSCOM commander with the sourcing and management of sustainment $\mathrm{EAB}$ units, coordinates sourcing requirements with the SB commanders, and assists the FORSCOM commander with the tactical, functional training of SBs in support of FORSCOM's ARFORGEN cycle. While merging the field- and sustainment-level capabilities through agreements and assisting logistics organizations with

\footnotetext{
${ }^{119}$ Headquarters, Army Field Support Battalion - Hood, Army Field Support Battalion Provides Sustainment Services to Fort Hood Units, 2.

${ }^{120}$ Headquarters, 13th Sustainment Command (Expeditionary), "Wrangler SOC provides 'Onestop Shop' for Fort Hood logistical needs," Provider Base (Fort Hood, TX, Summer 2012), 8.

${ }^{121}$ The graphic depicting two ESC covering the CONUS was developed prior to the $593^{\text {rd }}$ Sustainment Brigade reflagging to the $593^{\text {rd }}$ ESC in June 2013. Headquarters, Army Materiel Command, and Headquarters, Army Forces Command, "Leveraging Sustainment Organizations within the Continental United States," 9.
} 
recommended functional training is a laudable step, "achieving the nest level of Unity of Effort will not occur until sustainment brigades and ESCs are unified under a common command with DOLs and AFSBs." 122 Taking the idea of LSOC a step further, comparing the graphic depiction of "CONUS LSOC Responsibilities" (below), with the "Notional Global Logistics Command Structure" and the "Notional Regional ESC Support to CONUS" depicted on pages 5 and 59 respectively, the LSOC concept only lacks unity of command to ensure success across the CONUS-based Army.

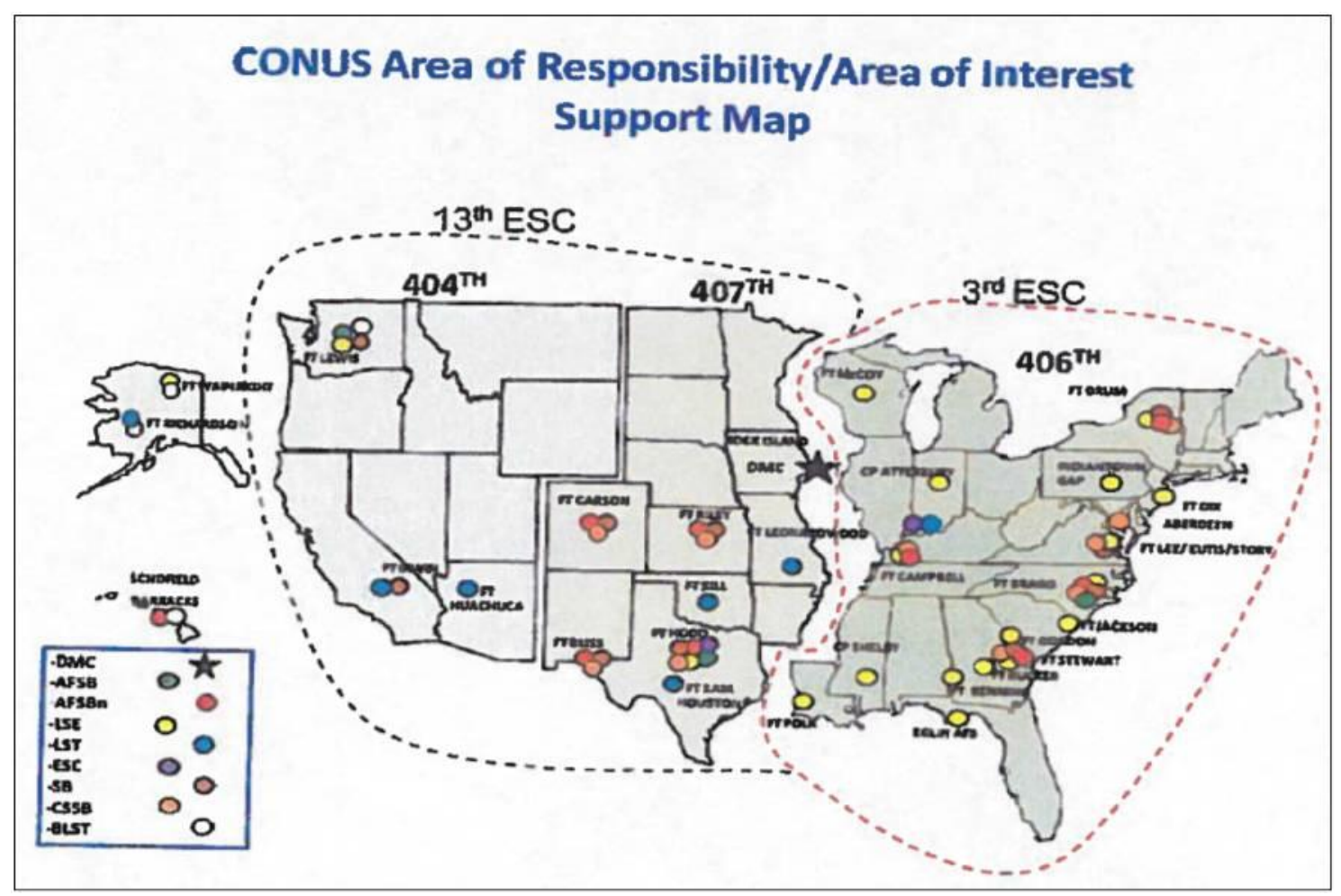

Figure 3. CONUS LSOC Responsibilities.

Source: Headquarters, Army Materiel Command, and Headquarters, Army Forces Command. "Leveraging Sustainment Organizations within the Continental United States," Memorandum of Command, 15 . 
Agreement between United States Army Forces Command and Army Materiel Command. May 20, 2011, 9 .

\section{Sustainment Operations Center (SOC)}

The role of the Sustainment Brigade is to execute sustainment support on an area basis.

On installations with SBs, the brigade provides TRA to all functional subordinate units, plans and executes materiel management and distribution, and tactical-level sustainment on their respective installations. For this reason, FORSCOM considerers the SB commander "the lead synchronizer and senior sustainment adviser across the division and installation." 123 Under the LSOC construct, SBs plan and execute materiel management and distribution guidance from the ESCs and coordinate with ASC/ESC materiel managers for asset management, visibility, and distribution to support divisions, brigades and other units on their assigned installations. According to the article Synchronizing Field and Sustainment Support: Roles and Responsibilities after 10 Years of War, the SOC:

... takes all the expertise and depth that reside in the sustainment brigade and synchronizes those functions with representatives of the installation support team, the sustainment-level support team, and the division $\mathrm{G}-4$ to provide that single stop for the BCTs, EAB tenant units, and other units transiting the AOR that require support and the enterprise sustainers who want to support them. The SOC in effect lowers the walls and enables a fusion of communication and coordination within the field level of logistics. ${ }^{124}$

In other words, because the LSOC concept relies on the close ties between AMC and FORSCOM logistics organizations, FORSCOM installations established a SOC to provide a single face to the installation.

${ }^{123}$ Colonel Todd A. Heussner; Lieutenant Colonel Geoffrey C. De Tingo; Lieutenant Colonel Craig M. Short, "Synchronizing Field and Sustainment Support: Roles and Responsibilities after 10 Years of War," Army Sustainment 44 no. 4 (July - August 2012), http://www.almc.army.mil/alog/ issues/JulAug12/Synchronizing_Field_Sustainment.html (accessed October 3, 2013).

${ }^{124}$ Ibid. 
While the SOC and LSOC concepts work well to provide central coordination points, execute operations in accordance with established FORSCOM priorities, and provide visibility to senior commanders for all logistics issues on FORSCOM installations, no such organization exists at non-FORSCOM installations. By creating a single, integrated logistics command, the ASC can tie both LRCs and EAB logistics formations directly into a globally-networked logistics command capable of expanding on the efficiencies it has already realized. ${ }^{125}$ With ESCs serving as subordinate operational commands to a three-star ASC, the ESCs current supervisory and materiel management role would expand to every installation in the CONUS achieving both immediate cost savings and future cost avoidance as idle capacity on installations could be leveraged to conduct missions across the CONUS. The current SOC concept, as the single point of contact for sustainment support on an installation, would become the mainstay at all forty-nine CONUS installations and would serve as an easily reproducible, best practice at the twenty-four overseas installations.

\section{Army Sustainment Command - The Logistics Corps}

With the establishment of a three-star ASC operating as the CONUS TSC, the command can leverage the three regionally-aligned ESCs to serve as the Western Hemisphere TSC supporting both ARNORTH and USARSO. As the supporting agency for both ASCCs, ASC becomes the primary synchronizer for logistics support planning and, during crisis, may deploy an ESC headquarters as part of a JTF. This two-tiered relationship between the ASC, its regional ESC, and the ASCCs not only provides the ASCC with experienced logistics planners and

\footnotetext{
${ }^{125}$ Headquarters, Army Sustainment Command, White Paper the United States Army Sustainment Command, 15.
} 
habitual relationships, it also provides flexible response options should one or more ESCs become unavailable to respond to a western hemisphere crisis.

The primary responsibilities of a four-star (strategic) headquarters are establishing priorities, resourcing programs and developing policy to include doctrine. Command at the strategic level assumes a certain level of detachment from the day-to-day operations which take place at the tactical-level (brigade and below) and requires a layering of subordinate headquarters to aggregate resource requirements and reduce the "noise" of unnecessary information which siphons away the finite resources of the strategic headquarters. One of the problems facing AMC today is the lack of a true operational-level subordinate headquarters capable of translating high operational "means" to strategic "ends," forcing the strategic headquarters to focus on the "ways" in which its subordinate commands operate (at the tactical-level). This condition would be akin to FORSCOM managing the varying needs of ten divisions (two-star) without corps (three-star) headquarters or TRADOC managing the individual school houses (one \& two-star) without the Centers of Excellence (CoE) (one \& two-star) to aggregate and prioritize requirements. ${ }^{126}$ For AMC, designating ASC as a three-star headquarters and CONUS TSC with the ESC serving as

\footnotetext{
${ }^{126}$ Not all TRADOC schoolhouses and Centers of Excellence (CoE) are organized the same. Four Centers of Excellence comprise eleven schoolhouses to include: Maneuver CoE houses the Infantry and Armor schools; Fires CoE houses the Artillery and Air Defense Artillery schools; Maneuver CoE houses the Engineer, Chemical, and Military Police schools; Sustainment CoE houses Ordinance, Transportation, Quartermaster, and the Soldier Support Institute. The Combined Arms Center, a 3-star headquarters, houses the Mission Command $\mathrm{CoE}$, Intelligence $\mathrm{CoE}$, Signal $\mathrm{CoE}$ and Aviation CoE. Other major subordinate commands of TRADOC include the Director of Army Capabilities Integration Center, the higher headquarters of the Brigade Modernization Command, the Army Recruiting Command, Cadet Command, and Initial Military Training Command. Headquarters, Training and Doctrine Command, "TRADOC Organization, June 28, 2013," under “Organization," http://www.tradoc.army.mil/FrontPageContent/Docs /TRADOC\%20Org\%20(28\%20Jun\%2013).pdf (accessed December 4, 2013).
} 
the tactical to operational "translators," the Global Logistics Command could refocus away from the execution of brigade-level missions to priorities, programs, and policies. ${ }^{127}$

\section{Army Sustainment Command in the Global Logistics Command}

Under the three-star ASC (CONUS TSC), the ESC serves in the capacity of a CONUSbased, regionally-focused, operational-level logistics headquarters responsible for the synchronization of all logistics support above the brigade-level for both institutional and operational Army units as well as providing mission command, including TRA, to SBs, AFSBs, and LRCs. These organizations primary missions are direct supporting to the ARFORGEN process, managing the Army's materiel, and providing logistics planning and theater logistics preparation to ARNORTH and USARSO. Included in these responsibilities are support to reserve units and integrating reserve force structure into home station training. Therefore, adding the ESCs as the "translator" of tactical requirements to the operational (three-star) headquarters provides AMC the much-needed distance from the tactical problem.

${ }^{127} \mathrm{AMC}$ has three subordinate units, which operate brigade level headquarters: Army Sustainment Command (ASC) has seven AC Army Field Support Brigades, Surface Deployment \& Distribution Command (SDDC) has five AC Transportation Brigades, and Expeditionary Contracting Command (ECC), a subordinate of Army Contracting Command (ACC) has seven AC Contracting Support Brigades. Headquarters, Army Materiel Command, "Army Materiel Command Organizational Structure, January 1, 2014," under "Organization, Major Subordinate Commands," http://www.amc.army.mil/amc/msc.html (accessed January 6, 2014). 


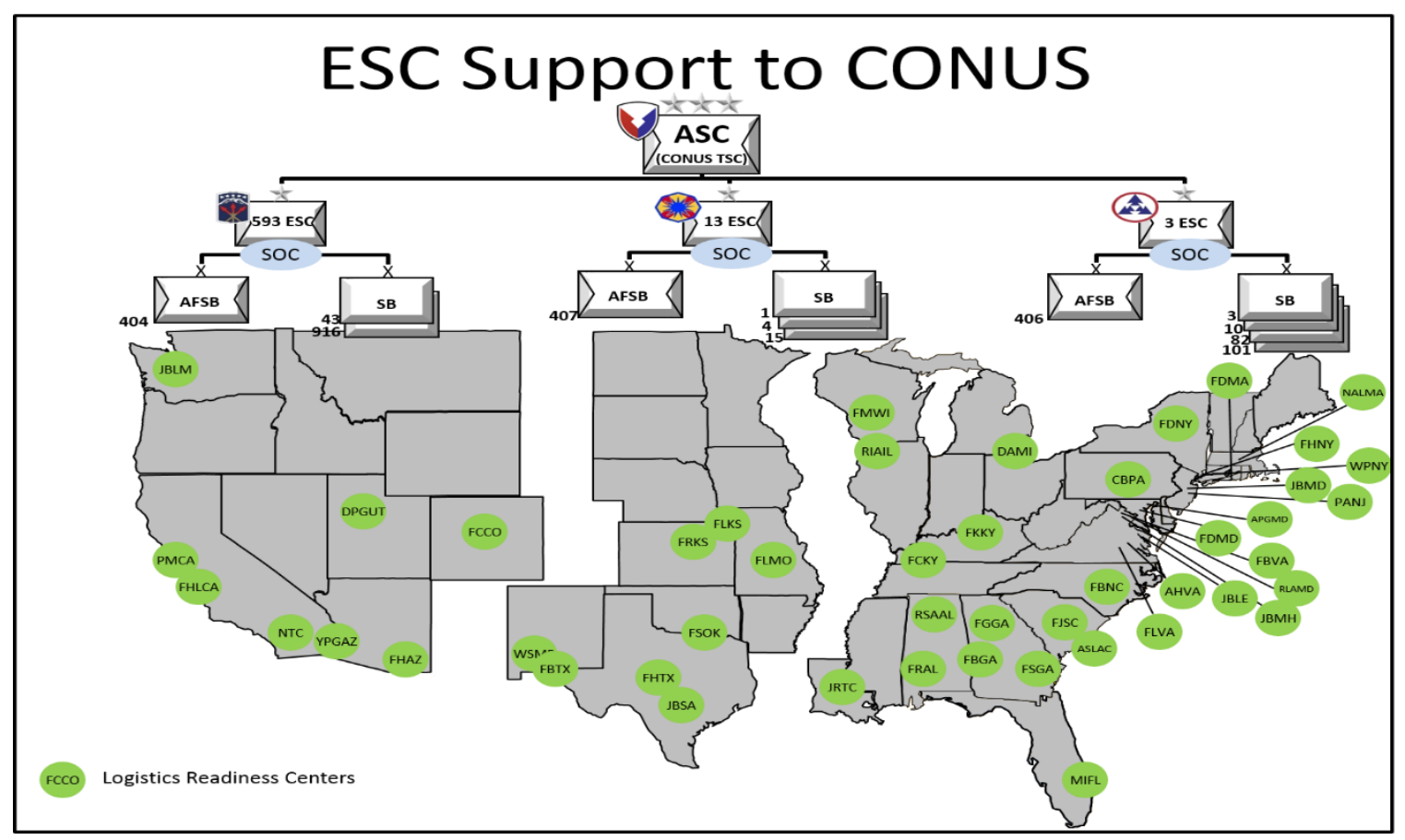

Figure 4. Notional Regional ESC Support to CONUS.

Source: Modified from unpublished briefing slide, Headquarters, Army Sustainment Command, Jan 2013.

Streamlining EAB logistics organizations under a regionally-focused ESC enables integration of logistics capabilities, cuts non-value-added redundancy, and maintains the current SOC concept of a single point of contact for sustainment support on an installation. At the individual installation, the LRC serves as the core logistics support agency. Combining the LRCs with the EAB sustainment capabilities residing in the SBs and AFSBs provides a wide variety of capabilities on the installation from running the dining facility to executing the full range of ARFORGEN tasks, depending on the capabilities required on the installation. During times when major support organizations deploy, the LRC (AFSB or AFSBn on larger installations) provides a mechanism to continue installation support since AFSB, AFSBn and LRCs are largely populated 
with Department of the Army Civilians; the impact of the deployment of a SB or other tactical logistics units could thus be minimized.

\section{Conducting Materiel Management in the CONUS TSC}

One of the greatest advantages of the CONUS TSC is its ability to conduct the Army's materiel management from the enterprise level. Since 2006, the Distribution Management Center (DMC), under the ASC, has carried out materiel readiness management in support of FORSCOM materiel prioritization. This support assisted FORSCOM in providing the right equipment to deploying units as they moved along the ARFORGEN cycle. Adding to their ability to manage the Army's readiness, on February 15, 2012, ASC became the executive agent for the Lead Materiel Integrator, and DMC, the single manager of Army equipment to ensure units and soldiers have the proper materiel at the right time and place to accomplish missions and training. ${ }^{128}$ From a materiel management perspective, the DMC outgrew its role as FORSCOM's materiel provider and is now the Army's Materiel Management Center, supporting readiness for both CONUS and OCONUS units.

Today, the ASC provides all of the Army's equipment sourcing from a single, central location at the headquarters leaving both the planning and execution to a single entity. Under the CONUS TSC, the DMC would have the capacity to conduct equipment resourcing on a regional basis through its ESC materiel management centers. These centers, while too small today, would grow with personnel provided by the former LCMC item managers, making each regional MMC capable of conducting stand-alone materiel management both in the CONUS and in an

\footnotetext{
${ }^{128}$ Headquarters, Army Sustainment Command, "Distribution Management Center - Lead Materiel Integrator," The ASC History News Letter 1, no. 10 (July 15, 2011), http://www.aschq.army.mil /supportingdocs/HistoryNewsJuly2011.pdf (accessed August 26, 2013).
} 
expeditionary environment. In addition, by moving the planning, unit training, and representation at the Unit Equipping and Reuse Working Groups away from the headquarters, the DMC would become a policy-focused organization leaving a small cell to handle OCONUS materiel management and cross regional coordination. ${ }^{129}$ While the current concept recognizes the efficiency of a single materiel manager, it fails to realize the extraordinary workload placed on a single manager who is responsible for plans, policy, and execution. What creates a global and dependable materiel management system is the CONUS TSC conducting materiel management at the ESC.

\section{Direct Support to ARFORGEN}

In 2006, the Secretary of the Army approved the transformation force generating model known as Army Force Generation (ARFORGEN) and designated FORSCOM as the executive agent. Under the model, FORSCOM builds readiness of CONUS based Army forces and provides trained and ready units to combatant commanders through a cyclical process consisting of reset, train/ready, and available forces. Due to current fiscal constraints, FORSCOM changed the model from a continuous readiness cycle of all BCTs to a tiered readiness model. Known currently as the 2/2/2+1 methodology, FORSCOM provides the Army two Infantry Brigade Combat Teams, two Armor Brigade Combat Teams, two Stryker Brigade Combat Teams, one Combat Aviation Brigade, and a small enabler package at the highest level of readiness, which sacrifices the readiness of remaining forces to ensure a small, rapidly deployable force with follow-on capabilities. Under this construct, EAB logistics forces will likely revert to their pre-war condition, suffering from systemically low readiness rates and a lack of training ammunition or

\footnotetext{
${ }^{129}$ Headquarters, Department of the Army, Army Equipping Roles, Responsibilities, Procedures and Authorities (RRPA) (Washington, DC: Government Printing Office, September 10, 2013), http:// www.g8.army.mil/pdf/RRPA_10September2013.pdf (accessed December 28, 2013).
} 
opportunity. While the $2 / 2 / 2+1$ model ensures the Army maintains a credible deterrence force, the concept assumes the most likely Army missions require combat forces at the expenses of ready forces to conduct humanitarian relief or support to civil authorities.

Currently, a tiny fraction of AMC forces are considered in the ARFORGEN model restricting AMC's generation of combat power to the materiel needs (S- and R-rating) of units in the process. Moving EAB logistics organizations from FORSCOM to AMC could place a substantial burden on the ASC and AMC staffs to focus on the personnel and training requirements (P-and T-rating) to bring units to their designated C-rating. ${ }^{130}$ While developing a stand-alone system for AMC to conduct these activities would be cost-prohibitive, AMC could operate a small cell in the FORSCOM operations division, or G3, to leverage FORSCOM's proven systems. This cell would conduct ARFORGEN for sustainment units as well as coordinate direct support to non-sustainment unit ARFORGEN under the current FORSCOM ARFORGEN process without incurring a substantial financial burden or dividing the scarce readiness dollars.

${ }^{130}$ The Brigade Logistics Support Team (BLST) is an AMC team led by a Major or a Chief Warrant Officer, which consists of around twelve DA Civilians who specialize in maintaining the types of equipment resident at each of the BCT or CAB elements. The BLST team leader is counted in the ARFORGEN model. Commanders of all measured units determine and report a C-level that reflects their assessments of their units' ability to accomplish the core functions and provide the capabilities for which the units are designed. Four measurements: personnel (P-rating), equipment supply status (S-rating), equipment readiness/serviceability status (R-rating), and training (T-rating) support the C-level determination. These resource and training status measurements are determined using the four tier rating scale and provides insight into the reporting unit's tactical-level capability. The four-tiered reporting system is a graduated system of readiness where a " ' 1 ' indicates the unit possesses the required resources and training to accomplish or provide the core functions and fundamental capabilities for which it was designed or to undertake the mission it is currently assigned. A ' 4 ' denotes that the unit requires additional resources or training to accomplish or provide the core functions and fundamental capabilities for which it was designed or to undertake the mission currently assigned; however, the unit may be directed to undertake portions of the assigned mission with resources on hand." Headquarters, Department of the Army, AR 220-1 Army Unit Status Reporting and Force Registration - Consolidated Policies (Washington, DC: Government Printing Office, April 15, 2010), 12-13. 
The cell would report to the AMC G3 and support the tiered readiness of EAB logistics organizations as they prepare to support unified land operations. ${ }^{131}$

\section{The Western Hemisphere TSC}

From a planning and executing logistics C2 perspective, the alignment of the ESCs works to the advantage of both ARNORTH and USARSO as the Western Hemisphere TSC. In ARNORTH, the ASC is the CONUS TSC providing sustainment support to Army forces, with the ESCs focusing on specific support areas roughly analogous to the Federal Emergency Management Agency (FEMA) regions (See Figure 5). Once enabled to support HA/DR operations, the regionally-aligned ESC could provide a dedicated logistics C2 disaster response capability, providing movement control for reception, staging, onward-movement and integration (RSOI) of forces moving into the Joint Area of Operations (JOA). In addition to their innate ability to manage Army or joint logistics at the operational-level, the ESCs would have as part of their downtrace the LRCs, where Federal or Joint Forces stage and prepare for disaster response operations, known as Base Support Installations (BSI) in FEMA language. Similar to the ESCs regional focus in the CONUS, in Army South's area of responsibility, the ASC could serve as the USARSO TSC with ESCs providing the same type of regional focus, e.g. $3^{\text {rd }}$ ESC could support the Caribbean, $13^{\text {th }}$ ESC supports Central America and 593 ${ }^{\text {rd }}$ ESC supports South America. Supporting two ASCCs, a Western Hemisphere TSC emerges with mission requirements similar

\footnotetext{
${ }^{131}$ The central idea of Unified Land Operations is that, "Army units seize, retain, and exploit the initiative to gain and maintain a position of relative advantage in sustained land operations to create conditions for favorable conflict resolution. This central idea applies to all military operations - offensive, defensive, and stability or defense support of civil authorities. This unifying principle connects the various tasks Army forces may perform. It adds the founding principles of flexibility, integration, lethality, adaptability, depth, and synchronization. It incorporates the principle that operational art is the connection between strategic objectives and tactical actions, and provides a common construct for organizing military operations. The construct consists of the Army operations process, an operations framework for visualizing and describing operations, and the warfighting functions." Headquarters, Department of the Army, ADP 3.0 Unified Land Operations (Washington, DC: Government Printing Office, October 2011), 5.
} 
to the $21^{\text {st }}$ TSC in Europe supporting both Army operations in both Europe and Africa. Like the $21^{\text {st }}$ TSC in Europe, the ASC would be responsible for supporting both ARNORTH and USARSO, with the additional capabilities of the CONUS-based ESCs.

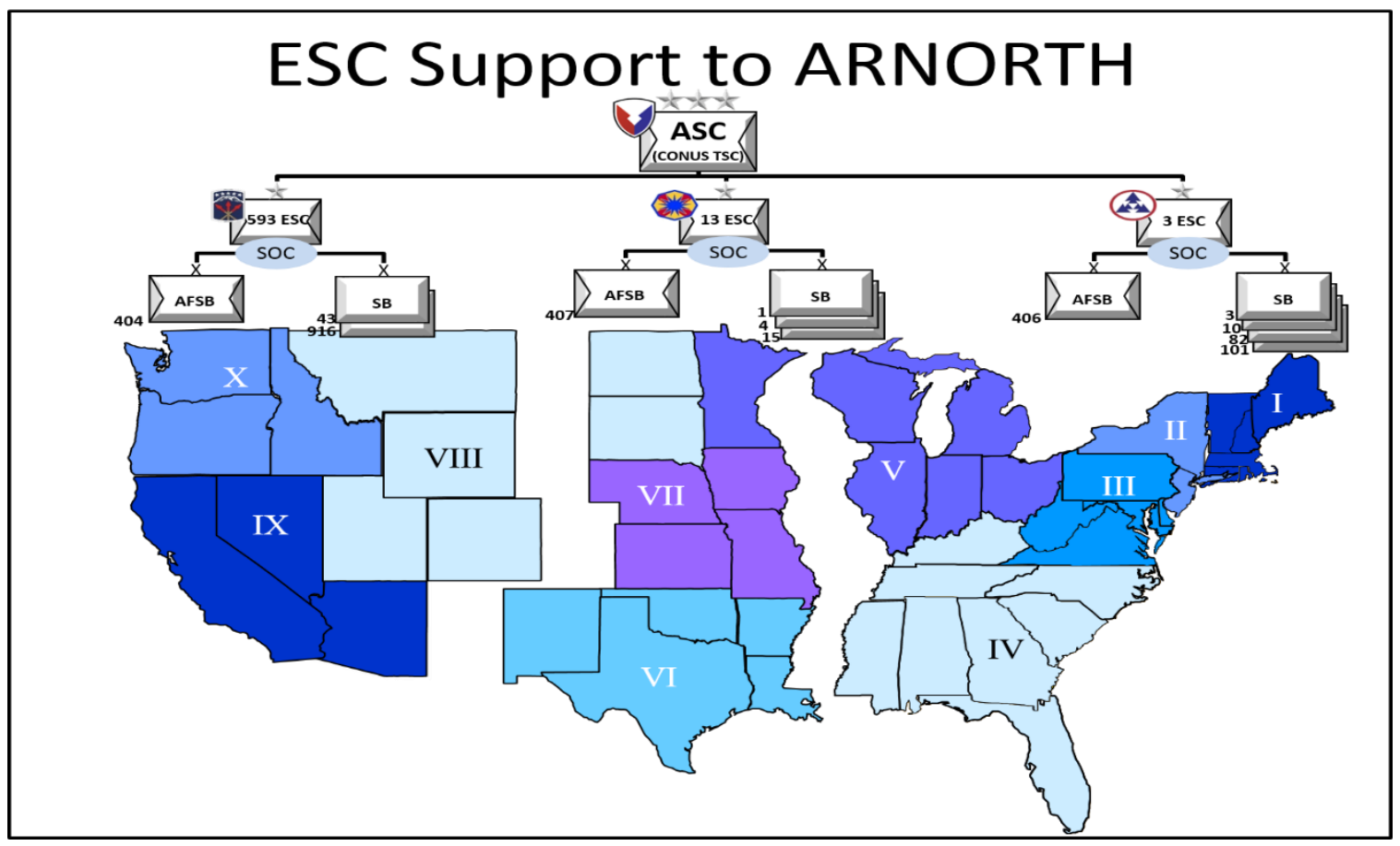

Figure 5. FEMA Regions Overlaid on ESC Regions.

Source: Derived from FEMA Regional Map found at http://www.fema.gov/regional-operations, and modified to include the notional CONUS TSC.

The establishment of the ASC as the Western Hemisphere TSC works to the advantage of the Army and the two western hemisphere ASCCs from the installation, through the region, to the CONUS base without degradation to its global mission. At the installation-level, ASC's LRC synchronize tactical logistics and unit deployment to ensure installation support remains consistent, as they do today. At the regional-level, the concept enables the development of a 
regional LCOP providing the ESC commander the ability to align capabilities to requirements within the region or to meet a surge capacity such as supporting deploying or returning units. The concept also ensures sufficient redundancy to allow ESCs to fulfill their expeditionary responsibilities in support of contingency operations without posing significant risk to the western hemisphere. In the CONUS base, the Western Hemisphere TSC commander can provide ARNORTH and USARSO with a dedicated planning and executing logistics C2 element, with built-in, value added redundancies to support DSCA operations in both ARNROTH and USARSO, and a clear picture of what sustainment capabilities are on hand.

\section{The Strategic Support Command}

In addition to formalizing the $\mathrm{C} 2$ relationships for operational logistics forces, the downsizing of excess headquarters due to discretionary spending caps requires the logistics community to cut unnecessary redundancy without cutting capability. By divesting the operationally-focused LCMC responsibilities, such as item management to the three-star ASC and its ESCs, a single Strategic Support Command (SSC) becomes strategically-focused on the life cycle of the equipment in concert with the Assistant Secretary of the Army for Acquisition, Logistics and Technology (ASA [ALT]) and Defense Logistics Agency (DLA) for "cradle to 
grave" equipment support. ${ }^{132}$ This consolidation of three two-star commands not only reduces

staff redundancies, but also consolidates every arsenal and depot potentially under one command, cutting operating costs across AMC installations. More importantly, a single command provides more than just unity of effort when it comes to developing sustainment strategies for Army equipment; the command delivers unity of command, providing the Army with a single voice to the acquisition community.

Beginning with the 2002 Future Logistics Enterprise (FLE) initiatives to redefine the conditions for Life Cycle Management (LCM) and carrying forward to the 2003 publication of Army Regulation 70-1, Army Acquisition Policy, the Army looked to address "traditional acquisition and logistics management concerns related to capabilities, development, operations

\footnotetext{
${ }^{132}$ According to their web page, the mission of the ASA [ALT] is to "provide our Soldiers a decisive advantage in any mission by developing, acquiring, fielding, and sustaining the world's best equipment and services and leveraging technologies and capabilities to meet current and future Army needs." Office of the Assistant Secretary of the Army for Acquisition, Logistics, and Technology, "Mission Statement," under "Mission," http://www.army.mil/asaalt/ (accessed January 16, 2013). According to the Defense Acquisition University, an Army Program Executive Officer is a "military or civilian official who has responsibility for directing several Major Defense Acquisition Programs (MDAPs) and for assigned major system and non-major system acquisition programs." Defense Acquisition University, Program Executive Officer (PEO) January 7, 2014, https://dap.dau.mil/acquipedia/Pages/ArticleDetails.aspx?aid=5f8e1f52-c933-4553-bc85-84aed4082c92 (accessed January 16, 2014). According to the Memorandum of Agreement between the Assistant Secretary of the Army for Acquisition, Logistics, and Technology and the Commander, U.S. Army Materiel Command, the commander AMC is responsible for "technology development; support to PEOs/PMs during the development, acquisition and fielding phases of the systems lifecycle; and integrated sustainment, planning, and execution. The support services that AMC provides to PEOs/PMs include technology research, development and engineering; acquisition logistics; contracting; procurement analysis; production; quality; industrial base analysis; sustainment logistics; and other support services as required." Assistant Secretary of the Army for Acquisition, Logistics and Technology and Commander, U.S. Army Materiel Command. "Life-Cycle Management (LCM) Initiative, Memorandum of Agreement, August 2, 2004." https://acc.dau.mil/adl/en-US/18587/file/741/Life-Cycle\%20Management\%20(LCM) \%20Initiative\%20Memorandum.pdf (accessed January 16, 2014), 2. According to the Defense Logistics Agency - Disposition Services website, the DLA-DS mission is, "in support of the DLA mission, DLA Disposition Services supports the Warfighter and protects the public by providing worldwide disposal management solutions." Headquarters, Defense Logistics Agency, "Mission Statement," under "Mission" http://www.dispositionservices.dla.mil/ index.shtml (accessed January 17, 2014).
} 
safety, and equipment and process failures, but also the new challenges posed by terrorism." ${ }^{133}$

The speed at which soldiers and commanders on the battlefield needed new, more advanced equipment outpaced the traditional acquisition and logistics systems. In an attempt to integrate the elements of the Acquisition, Logistics \& Technology (ALT) community with AMC's commodity commands, the AMC and ASA [ALT] established the 2004 LCMC initiative MOA to "get products to the Soldier faster, make good products even better, minimize life cycle cost, and enhance the synergy and effectiveness of the Army Acquisition, Logistics, and Technology (ALT) communities." 134

Under the MOA, the life cycle in LCMC refers to both the members of the organization and the phases of equipment acquisition. From the organizational perspective, the commodity command (AMCOM, CECOM, TACOM, and JMC) under AMC serves as the titular head of the triad which makes up the LCMC, with the remainder of the LCMC the representatives from the Program Executive Offices (PEO), part of the ASA [ALT] community, and the Army Research and Development Center from the U.S. Army Research, Development and Engineering Command (RDECOM). From the equipment acquisition standpoint, the life cycle refers to the

\footnotetext{
${ }^{133}$ Lieutenant Colonel Michael P. Flanagan, "Life Cycle Management Commands: Wartime Process or Long-Term Solution?” (Research Paper: United States Army War College, 2007), 10.

${ }^{134}$ Assistant Secretary of the Army for Acquisition, Logistics and Technology and Commander, U.S. Army Materiel Command, "Life-Cycle Management (LCM) Initiative Memorandum of Agreement, August 2, 2004," 1.
} 
time between research, technology development, system development and demonstration (SDD), production, operations and sustainment $(\mathrm{O} \& S)$, and disposal. ${ }^{135}$

With the 2004 inception of the LCMC structure came the ability for the individual LCMCs to provide better equipment faster to America's deployed forces based on in-theater requirements. Those requirements were either top driven operational needs statements, such as the need for Mine Resistant Ambush Protective (MRAP) vehicles, or bottom driven soldier ingenuity, such as minor modifications to existing equipment to improve quality, reliability, or survivability. ${ }^{136}$ Unfortunately, the success of the four autonomous procurement systems came without a built-in AMC mechanism to ensure, for example, up-armor kits developed by the TACOM LCMC would marry up with already installed communications systems developed by

${ }^{135} \mathrm{As}$ an example, the TACOM LCMC is responsible for the Army's soldier and ground combat systems and includes the original TACOM commodity command, PEO Ground Combat Systems (PEO GCS), PEO Combat Support Combat Service Support (PEO CS/CSS), PEO Soldier (PEO Soldier), as well as the TACOM Research and Development Center (TARDEC). The Commanding General of TACOM is the titular head of the TACOM LCMC but does not have command responsibilities for each of the organizations. The PEOs continue to report directly to ASA (ALT) and the Director of TARDEC reports directly to the Commander, Research, Development and Evaluation Command (RDECOM). The other three LCMCs are organized similarly and designated: the Aviation/Missile LCMC (formerly Aviation and Missile Command (AMCOM)), the Communications/Electronics LCMC (formerly Communications Electronics Command (CECOM)), and the Joint Ammunition LCMC (formerly Joint Munitions Command (JMC) in Army Field Support Command (AFSC)). Flanagan, "Life Cycle Management Commands," 12.

${ }^{136}$ In Iraq and Afghanistan, two AMC organizations were pivotal in developing both requirements for improved survivability of end items and for incremental modification of equipment. Research and Development Command (RDECOM) deployed the Filed Assistance in Science and Technology (FAST) teams and the Tank and Automotive Command (TACOM), Industrial Base Operations Directorate, deployed several Mobile Parts Hospitals (MPH). The FAST is a cell within the RDECOM headquarters with forward teams of science and technology experts who "provide commanders immediate access to labs and centers in AMC's RDECOM and expedites technology solutions to soldiers." Headquarters, Research, Development, and Engineering Command, "Field Assistance in Science and Technology, 2012," under "FAST: Field Assistance in Science and Technology," http://www.rdecom.army.mil/FAST/ (accessed December 25, 2013). The TACOM MPH "is a self-contained, self-sustaining mobile manufacturing system that efficiently fabricates existing standard, custom parts, and new parts at or near the point of need to enhance Soldier readiness." The MPH can reverse engineer parts or tools and fabricate small quantities in a short period to expedite the repair of end items with long lead-time parts or hard to acquire tools. The MPH also works from existing drawings or specifications to create new parts in order to modify or enhance equipment. Rebecca Montgomery, "TACOM LCMC Resets Mobile Parts Hospital Slated for Use in Iraq" Army (July 14, 2008), under "Article," http://www.army.mil/article/10864/TACOM_LCMC_resets_ mobile_parts_hospital_slated_for_use_in_Iraq/ (accessed December 25, 2013). 
the CECOM LCMC. These interoperability issues continually challenged in-theater logisticians, leading to on-the-fly solutions in the combat zones and increased costs as third party contractors implemented the solutions. With the drawdown of large-scale deployed forces from Afghanistan and as requirements generation for major procurement projects move from the needs of the combat zones to the needs of the Army, headquarters and procurement systems must consolidate into a single equipment procurement and sustainment focused headquarters. Under a consolidated Strategic Support Command (SSC), a single commander would ensure unity of effort across a collaborative procurement environment and maintain unity of command as the singular voice of the materiel enterprise.

\section{Looking Back to see the Future}

Looking back to the mid-1990's and the Revolution in Military Logistics, logistics leaders already envisioned an AMC that was a true Global Logistics Command, and a CONUS TSC.

Some ten years after the concept emerged, Major General Wade "Hamp" McManus, commander

of Army Field Support Command wrote of the future organization:

I intend to develop the Army Field Support Command (AFSC) into a Joint Field Support Command (JFSC) as an extension to logistics transformation . . . The current distribution process together with deploy, employ, and sustain need linked into a single operational process. This allows for a rapid response from various continental United States (CONUS) and forward presence locations to any geographic location in a rapid and ready succession ... This mandates a need for a single executive agent responsible for logistics support in a JOINT [sic] environment, with a capability-based and operationally oriented approach to support multiple contingencies simultaneously. ${ }^{137}$

\footnotetext{
${ }^{137}$ A review of Army literature and briefings developed in the decade after the 1996, Joint Vision 2010 and 1997, Army Vision 2010, shows that Army logisticians were enamored with the idea of standing joint logistics headquarters such as Joint Theater Support Command. In current literature, a standing joint logistics headquarters is largely omitted. Currently, there are few examples of functioning joint logistics headquarters, such as the Joint Sustainment Command - Afghanistan (JSC-A). Major General Wade H. "Hamp" McManus, "White Paper: Establishing a CONUS Logistics Sustainment Base in Support of the Joint and Expeditionary Mindset," (Paper, Army Sustainment Command, Rock Island, IL, 2004), 1.
} 
In other words, in 2004, senior Army logisticians realized the systems that were in place to deploy, employ, and sustain forces from the CONUS base to the theater were a hodgepodge of disparate organizations, which needed centralization to become more efficient. Unfortunately, since 2004 very little has changed with regard to how the Army deploys and sustain forces at home station or abroad.

Some fifty years following the inception of AMC, the command has proven its ability to support anywhere and at any time, but it is time for the logistics community to transform again. Today, a downsizing Army requires a new approach to the way it organizes and sustains itself. Supporting a smaller, CONUS-based Army requires a different logistics command than the one that served the Army in OIF and OEF. Through years of honing logistics support and developing systems that bring the foxhole closer to the factory, AMC is poised to develop a new logistics command - the Global Logistics Command. With its operational and strategic arms, this command will be capable of supporting the total Army. Operationally, the ASC will support everything from small-scale, small-footprint missions around the globe with pre-positioned stocks and LOGCAP contractors to major regional conflicts, leveraging the range of tactical to operational logistics forces. Strategically, the command will continue to develop and sustain the systems upon which soldiers rely on for lethality and survivability. Implementation of the Global Logistics Command is the right sustainment solution for the next fifty years. 


\section{BIBLIOGRAPHY}

Anderson, David A., and Dale L. Farrand. "An Army Revolution in Military Logistics," Army Logistician: Professional Bulletin of United States Army Logistics (July-August 2007): http://www.almc.army.mil/alog/issues/JulAug07/log_revolution.html (accessed July 13, 2013). 19-23.

Assistant Secretary of the Army for Acquisition, Logistics and Technology and Commander, U.S. Army Materiel Command. "Life-Cycle Management (LCM) Initiative, Memorandum of Agreement, August 2, 2004.” https://acc.dau.mil/adl/en-US/18587/file/741/LifeCycle\%20Management\%20(LCM)\%20Initiative\%20Memorandum.pdf (accessed January 16, 2014).

Association of the United States Army. "U.S. Army North/Fifth Army: Building Relationships for a Secure Homeland," Torchbearer Issue Papers, December 2011. http://www.ausa .org/publications/torchbearercampaign/torchbearerissuepapers/Pages/default.aspx (accessed December 5, 2013).

"Army Prepositioned Stocks: Indispensable to America's Global Force-projection Capability," Torchbearer Issue Papers, December 2008. http://www.ausa.org/ publications/torchbearercampaign/torchbearerissuepapers/Pages/default.aspx (accessed December 5, 2013).

Center for Army Lessons Learned. "Logistic Preparation of the Battlefield, September 17, 2008." http://usacac.army.mil/cac2/call/ (accessed July 28, 2013).

Coburn, John G., and Robert M. Walker. Preparing for the Revolution in Military Logistics, Washington, DC: Government Printing Office, 1997.

Defense Acquisition University. "Program Executive Officer (PEO) January 7, 2014.” https://dap.dau.mil/acquipedia/Pages/ArticleDetails.aspx?aid=5f8e1f52-c933-4553-bc8584aed4082c92 (accessed January 16, 2014).

Department of Defense. "Western Hemisphere Defense Policy Statement, October 2012." http://www.defense.gov/news/WHDPS-English.pdf (accessed August 23, 2013).

Dixon, Robert J. "Examining U.S. Army Logistics: Determining Relevance for $21^{\text {st }}$ Century Operations." Monograph, School of Advanced Military Studies, Fort Leavenworth, KS, 2012.

Donnelly, Thomas, and Frederick W. Kagan. Ground Truth the Future of U.S. Land Power. Washington, DC: The American Enterprise Institute for Public Policy Research, 2008.

Eaton, George. "Creating AMCs Face to the Field: The US Army Sustainment Command under MG Jerome Johnson, June 2004-July 2007.” Paper, Army Sustainment Command, Rock Island, IL, July 30, 2007. 
Eisenhower, Dwight D. The Farewell Address. January 17, 1961. http://www.eisenhower .archives.gov/ research/online_documents/farewell_address.html (accessed September $25,2013)$.

Feickert, Andrew. U.S. Army's Modular Redesign: Issues for Congress. "CRS Report for Congress.” Washington, DC: Congressional Research Service. January 6, 2005. http://www.fas.org/man/crs/RL32476.pdf (accessed November 10, 2013).

Fick, Charles W. Jr. “Army Materiel Command Merges Units in Europe,” Pentagon Brief. no. 8, 2004. http://search.proquest.com/docview/215563748?accountid=28992 (accessed September 25, 2013).

Flanagan, Michael P. "Life Cycle Management Commands: Wartime Process or Long-Term Solution?” Research Paper. United States Army War College, Carlisle Barracks, PA, 2007.

Glass, E. M. "Findings from Recent Studies of the Defense Laboratories by the Task 97 Action Group." Washington, DC: Office of the Director of Defense Research and Engineering, December 7-8, 1964. http://www.dtic.mil/cgi-bin/GetTRDoc?AD=AD0637203 (accessed July 12, 2013).

Hawkins, Kari. “AMC-developed weapons remain vital to Army,” Redstone Rocket. 2012. http://www.theredstonerocket.com/tech_today/article_ca4a4998-0db3-11e2-a32a0019bb2963f4.html?mode=jqm (accessed September 27, 2013).

"Army Materiel Command Grows Mission with Needs of Nation" Army News Service. August 1, 2012. http://www.army.mil/article/84767/ (accessed July 13, 2013).

Headquarters, $13^{\text {th }}$ Sustainment Command (Expeditionary). "Wrangler SOC provides 'Onestop Shop' for Fort Hood logistical needs," Provider Base. Fort Hood, TX, Summer 2012. http://static.dvidshub.net/media/pubs/pdf_10857.pdf (accessed November 10, 2013).

Headquarters, Army Field Support Battalion - Hood, 407th Army Field Support Brigade. "Army Field Support Battalion Provides Sustainment Services to Fort Hood Units." The Mighty407th Fall 2011, http://www.osc.army.mil/supportingdocs/FINAL_Mighty407th _F2011_WEB.pdf. (accessed July 12, 2013). 16-17.

Headquarters, Army Field Support Command. Evolving the AFSC as the Joint Logistics Support Command (JLSC). Rock Island, IL: Army Field Support Command Publication, May 26, 2004.

Headquarters, Army Forces Command. "ARFORGEN Overview.” Presentation, U.S. Army Forces Command, Ft. Bragg, NC, July 22, 2009. http://www.marad.dot.gov/ documents/NPRN_WS_2009_Workshop_1_FSLDC_10-1_ARFORGEN _ Overview.pdf (accessed January 16, 2014). 
Headquarters, Army Materiel Command. Arsenal for the Brave: A History of the United States Army Materiel Command 1962-1968. Alexandria VA: U.S. Army Material Command Publication, September 30, 1969.

_. "Locations," Army Materiel Command Organizational Structure. January 1, 2014. http://www.amc.army.mil/amc/msc.html (accessed January 6, 2014).

__. "U.S. Army Materiel Command Annual Historical Review Fiscal Year 1966." Alexandria, VA: U.S. Army Material Command Publication, 1967.

Headquarters, Army Materiel Command, and Headquarters, Army Forces Command. "Leveraging Sustainment Organizations within the Continental United States, Memorandum of Agreement between United States Army Forces Command and Army Materiel Command.” May 20, 2011.

Headquarters, Army Sustainment Command, United States Army. "Armament, Munitions, and Chemical Command - AMCCOM," The ASC History News Letter 2, no. 7. http://www.aschq.army.mil/supportingdocs/HistoryNewsApr2012.pdf (accessed August 20, 2012).

ASC and GL2020 MC Slides. Presentation, U.S. Army Sustainment Command, Rock Island, IL, January 14, 2013.

_. "Creation of Army Materiel Command," The ASC History News Letter 2, no. 6. http://www.aschq.army.mil/supportingdocs/HistoryNewsMar2012.pdf (accessed November 10, 2013).

"Field Support Command 2000-2003," The ASC History News Letter 2, no. 11 http://www.aschq.army.mil/supportingdocs/HistoryNewsAug2012.pdf (accessed August 20, 2013).

_. "Industrial Operations Command (IOC)," The ASC History News Letter 2, no. 8. http://www.aschq.army.mil/supportingdocs /HistoryNewsMay2012.pdf (accessed August 26, 2013).

"LOGCAP - Logistics Civil Augmentation Program," The ASC History News Letter 1, no. 11. http://www.aschq.army.mil/supportingdocs/HistoryNewsAug2011.pdf (accessed August 20, 2013).

—_. "Logistics Assistance Program (LAP)," The ASC History News Letter 2, no. 2. http: //www.aschq.army.mil/supportingdocs/HistoryNewsNov2011.pdf (accessed August 20, 2013).

"White Paper the United States Army Sustainment Command: Sustaining Army and Joint Forces 2020 and Beyond.” Paper, Army Sustainment Command, Rock Island, IL, November 2012. 
Headquarters, Army Training and Doctrine Command. "TRADOC Organization, June 28, 2013." http://www.tradoc.army.mil/FrontPageContent/Docs/TRADOC\%20Org\%20(28\%20Jun \%2013).pdf (accessed December 4, 2013).

Headquarters, Army War College. Army 2020 Tactical-Level Sustainment Support BCT and CSSB Conversions. Fort Lee, VA: Sustainment Center of Excellence, 2013.

Headquarters, Combined Arms Support Command. "Army 2020 and Beyond Sustainment White Paper.” Paper, Sustainment Center of Excellence, Ft. Lee, VA, 2013.

. "GLC Workshop \#2 Outbrief 1-2 Star GOSC," Global Logistics Concept Workshop. Presentation, Sustainment Center of Excellence, Fort Lee, VA, December 7, 2012.

—. "Operation Unified Response (OUR) Army Sustainment AAR General Officer Session 18 June 2010 Transcript of Proceedings." Presentation, Sustainment Center of Excellence, Fort Lee, VA, 2010.

Headquarters, Defense Logistics Agency. "Mission Statement.” http://www.dispositionservices. dla.mil/index.shtml (accessed January 17, 2014).

Headquarters, Department of Defense. Joint Publication 3-31 Command and Control for Joint Land Operations. June 29, 2010. http://www.dtic.mil/doctrine /new_pubs/jp3_31.pdf (accessed July 19, 2013).

Joint Publication 5-0 Joint Operational Planning. August 11, 2011. http://www.dtic. mil/doctrine/new_pubs/jp5_0.pdf (accessed July 19, 2013).

—. Sustaining U.S. Global Leadership: Priorities for 21st Century Defense. January 2012. www.defense.gov/news/defense_strategic_guidance.pdf (accessed July 19, 2013).

Headquarters, Department of the Army. "Army Materiel Command Stands-up Army Sustainment Command," Army News Service. October 23, 2006. http://www.army.mil/article/393/ (accessed July 13, 2013).

_. "Army Materiel Command welcomes Directorates of Logistics," Army News Service. October 24, 2012, http://www.army.mil/article/ 89844/ (accessed October 3, 2013).

“Army Materiel Command History: 1960s,” Army News Service. October 23, 2006. http://www.army.mil/article/85246/ (accessed July 13, 2013).

- A Brief History U.S. Army Industrial Operations Command. Rock Island, IL: Industrial Operations Command, 1999.

- ADP 3-0 Unified Land Operations. Washington, DC: Government Printing Office, October 2011.

- AR 220-1 Army Unit Status Reporting and Force Registration - Consolidated Policies. Washington, DC: Government Printing Office, April 15, 2010. 
AR 350-1 Army Training and Leader Development. Washington, DC: Government Printing Office, August 3, 2007.

Armament \& Munitions Community Organizational Evolution FY73-FY10.

Presentation, Rock Island, IL: Joint Munitions Command, 2011.

ATP 4-94 Theater Sustainment Command. Washington, DC: Government Printing Office, June 2013.

-. Deputy Chief of Staff, G-4 Operation Unified Response 17-18 June 2010 Sustainment AAR Summary, Washington, DC: U.S. Army G4, June 2010.

- "Operation Unified Response DA G-4 Army Sustainment AAR 17-18 June 2010."

Presentation, U.S. Army G-4, Washington, DC, June 2010.

- Permanent Order 055-1. Army Materiel Command History Office, Fort Belvoir VA:

Army Materiel Command, February 24, 2006.

. "The Materiel Enterprise: Materiel Solutions for our Soldiers," Army News Service.

November 2, 2009, http://www.army.mil/article/29721/The_Materiel_Enterprise

Materiel_solutions_for_our_Soldiers/ (accessed October 3, 2013).

- Theater Logistics CONOPS for Operation Unified Response: 17 June 2010, CASCOM

Sustainment AAR. Presentation, Fort Lee, VA: Sustainment Center of Excellence, June 2010.

. "Urgent Reform Required: Army Expeditionary Contracting Report of the 'Commission on Army Acquisition and Program Management in Expeditionary Operations'." (Report, Department of the Army, Washington, DC, October 31, 2007). http://www.army.mil/ docs/Gansler_Commission_Report_Final_071031.pdf (accessed January 21, 2014).

Headquarters, XVIII Airborne Corps. "Operation Unified Response XVIII Airborne Corps Jan Apr 2010 Initial Impressions Report.” XVIII Airborne Corps History Office, Fort Bragg, NC, 2010.

Heiser, Joseph M. Jr. Vietnam Studies Logistics Support. Washington, DC: U.S. Army Center of History, 1991. http://www.history.army.mil/ books/Vietnam/logistic/ (accessed August $23,2013)$.

Hewes, James E. Jr. From Root to McNamara Army Organization and Administration. Washington, DC: U.S. Army Center of History, 1975. http://www.history.army.mil /books/root/ (accessed August 23, 2013).

Heussner, Todd A., De Tingo, Geoffrey C., Short, Craig M. "Synchronizing Field and Sustainment Support: Roles and Responsibilities after 10 Years of War," Army Sustainment. Volume 44 no. 4. July - August 2012. http://www.almc.army.mil/alog/ issues/JulAug12/Synchronizing_Field_Sustainment.html (accessed October 3, 2013). 1922. 
Hilburn, Cofield B. "Transforming for Distribution Based Logistics." Monograph, School of Advanced Military Studies, Fort Leavenworth, KS, 2005.

Holland, Diana M. "Strengthening the Regiment: Training and Readiness Authority-Plus," Engineer. (January-April 2010). http://www.dtic.mil/dtic/tr/fulltext/u2/a560260.pdf (accessed July 21, 2013). 14-17.

Jacobs, Jeffrey A. "CCMRF and Use of Federal Armed Forces in Civil Support Operations," Civil Support and the U.S. Army 10-16. December 2009. http://usacac.army.mil/cac2 /call/docs/10-16/ch_14.asp (accessed July 21, 2013). 87-90.

Jobson, Rob W. and Peter M. Antell. U.S. Army Materiel Command: Essential in Peace, Indispensable in War. Tampa, FL: Faircount Publication, 2004.

Keen, P.K. (Ken), Elledge, Matthew G., Nolan, Charles W., Kimmey, Jennifer L. "Foreign Disaster Response Joint Task Force-Haiti Observations," Military Review. NovemberDecember 2010. http://usacac.army.mil/CAC2/MilitaryReview/Archives/English/ MilitaryReview_20101231_art015.pdf (accessed November 10, 2013). 85-96.

Lenaers, William M. and Coryell, Brent D. "Reset: Extending the Life of Army Equipment," Army Logistician. January-February 2006. http://www.almc.army.mil/alog/issues /JanFeb06/reset_armyeq.html (accessed November 18, 2013). 2-4.

Maccagnan, Victor. "Logistics Transformation-Restarting a Stalled Process." Research Paper, United States Army War College, Carlisle Barracks, PA, (2005).

McManus, Wade H. Jr. “ACP DP 54, 55 and 56 Update and CONUS TSC (Army Sustainment Command) presented to GEN Richard Cody, Vice Chief of Staff Army" Presentation, Army Materiel Command, Alexandria VA, June 7, 2005.

"How Army Transformation Affects Us.” Presentation, Rock Island, IL: Joint Munitions Command, Rock Island Arsenal, May 2003.

. "White Paper: Establishing a CONUS Logistics Sustainment Base in Support of the Joint and Expeditionary Mindset." Paper, Army Sustainment Command, Rock Island, IL, 2004.

Montgomery, Rebecca. TACOM LCMC Resets Mobile Parts Hospital Slated for Use in Iraq. July 14, 2008. http://www.army.mil/article/10864/TACOM_LCMC_resets_mobile_ parts_hospital_slated_for_use_in_Iraq/ (accessed December 25, 2013).

Myers, Laurel K, Ph.D. "Eliminating the Iron Mountain,” Army Logistician. July-August 2004, http://www.almc.army.mil/alog/issues/JulAug04/C_iron.html (accessed November 18, 2013). 40-43.

Odierno, Raymond T. "CSA Editorial: Prevent, shape, win," Army News Service. December 16, 2011. http://www.army.mil/article/71030/ (accessed December 5, 2013.) 
Office of the Assistant Secretary of the Army for Acquisition, Logistics, and Technology.

"Mission Statement." http://www.army.mil/asaalt/ (accessed January 16, 2013).

Petcoff, Russell. “AMC Birthed from 'Sweeping Reorganization' to Outfit Today's Soldiers," Army News Service. August 16, 2012. http://www.army.mil/article/85663/ (accessed July 13, 2013).

Pogue, Forrest C. The Supreme Command. Washington, DC: U.S. Army Center of History, 1954. http://www.ibiblio.org/hyperwar/USA/USA-E-Supreme/ (accessed August 23, 2013).

Reimer, Dennis J. “The Revolution in Military Logistics” Army Logistics Magazine. JanuaryFebruary 1999. http://www.alu.army.mil/alog/issues/JanFeb99/1999jan_feb/toc_ 99jf.pdf. (accessed July 13, 2013). 2.

Research, Development and Engineering Command. "Field Assistance in Science and Technology, 2012.” http://www.rdecom.army.mil/FAST/ (accessed December 25, 2013).

Roney, Christine D. “The Evolution of Centralized Operational Logistics." Monograph, School of Advanced Military Studies, Fort Leavenworth, KS, 2012.

Snow, Michael W. "Focused Logistics: Putting Agility in Agile Logistics.” Monograph, School of Advanced Military Studies, Fort Leavenworth, KS, 2011.

Trybula, David C. "Big Five Lessons for Today and Tomorrow." Research Paper, United States Army War College, Carlisle Barracks, PA, 2012. http://www.benning.army.mil/Library/ content/NS\%20P-4889.pdf (accessed June 28, 2013).

U.S. Congress. House. Planning for Sequestration in Fiscal Year 2014 and Perspectives of The Military Services On The Strategic Choices And Management Review.113th Cong., 1st sess. 2013. http://armedservices.house.gov/index.cfm/hearings-display?ContentRecord _id=71d1123f-51f8-4141-b6e7-28d782b427fe (accessed July 21, 2013).

U. S. National Archives. "Records of the United States Army Materiel Command, Record Group 544, 1941-73," http://www.archives.gov/research/guide-fed-records/groups /544.html (accessed July 21, 2013).

U.S. President. National Security Decision Directive. "Implementation of the Recommendations of the Blue Ribbon Commission on Defense Management, Decision Directive 219." (April 1, 1986). http://www.fas.org/irp/offdocs/nsdd/index.html (accessed December 4, 2013).

U.S. President. Proclamation. "United States Government Haiti Earthquake Disaster Response Update 1/21/10.” January 21, 2010. http://www.whitehouse.gov/the-press-office/unitedstates-government-haiti-earthquake-disaster-response-update-12110 (accessed September 19, 2013). 
U.S. Southern Command. "Operation Unified Response: Support to Haiti Earthquake Relief, 2010." http://www.southcom.mil/newsroom/Pages/Operation-Unified-Response-Supportto-Haiti-Earthquake-Relief-2010.aspx (accessed December 4, 2013).

Van Creveld, Martin. Supplying War, Logistics from Wallenstein to Patton. Cambridge: Cambridge University Press, 1977.

Via, Dennis L. "DOLs rebalanced as 'Logistics Readiness Centers'," The Fort Leavenworth Lamp. Fort Leavenworth, KS, October 24, 2013.

Williams, Rudi. “African-American Ascends from Private to Four-Star General," American Forces Press Service. February 19, 1998. http://webcache.googleusercontent.com /search?q=cache:XrMHFziFdTEJ:www.defense.gov/News/NewsArticle.aspx\%3FID\%3D 41545\&hl=en\&gl=us\&prmd=ivns\&strip=1 (accessed November 26, 2013).

Woods, Bryan. " $21^{\text {st }}$ TSC and USAFE Conduct Humanitarian Mission to Georgia," Blackanthem Military News. August 14, 2008. http://blackanthem.com/News/U_S_Military_19/21stTSC-and-USAFE-conduct-humanitarian-mission-to-Georgia18257.shtml (accessed November 13, 2013). 
Appendix 1. Changes to the Army's Sustainment Force Structure Caused by the Shift to Modularity, 1984-Present.

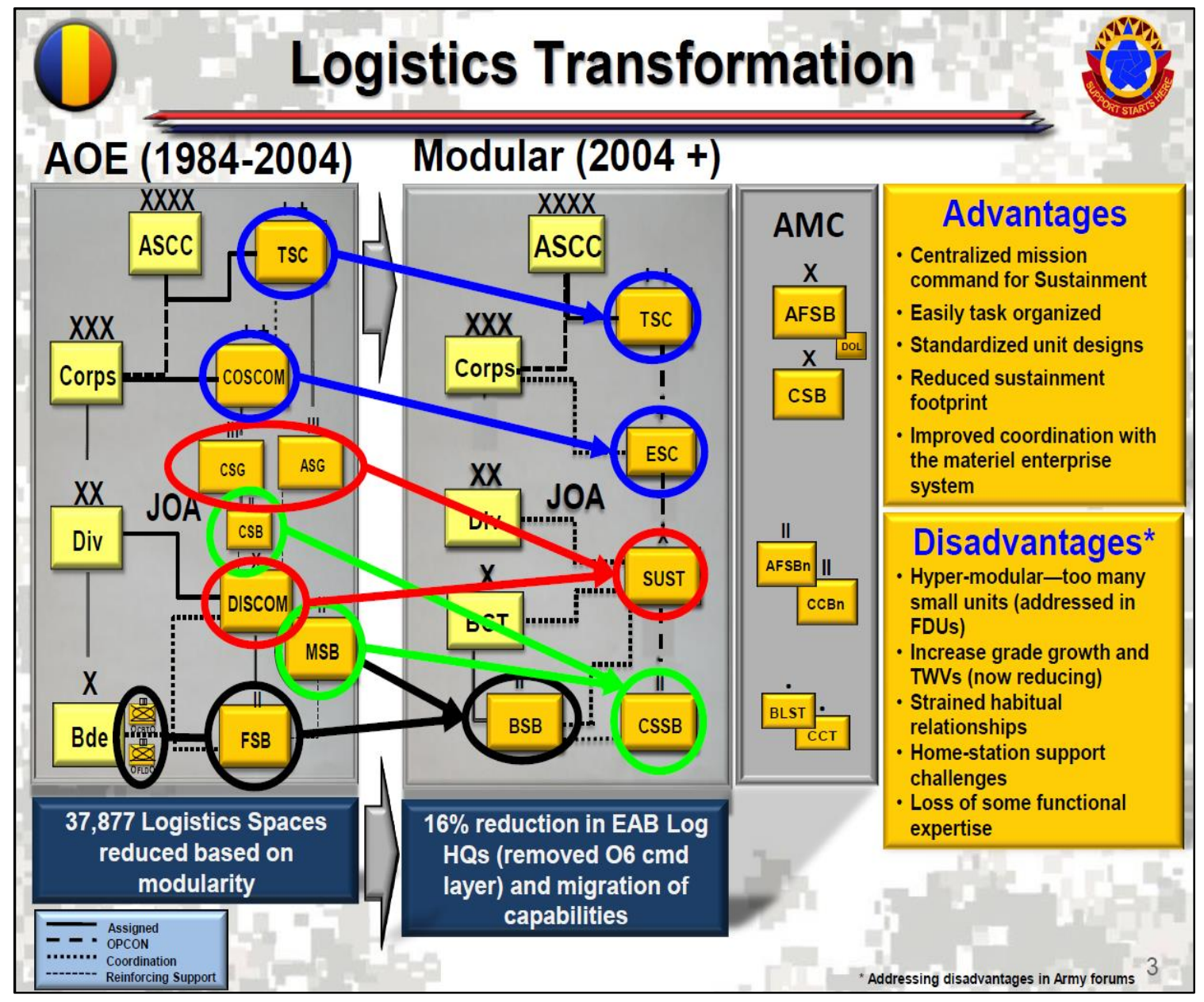

Source: Headquarters, Combined Arms Support Command, United States Army. Army 2020 Tactical-Level Sustainment Support BCT and CSSB Conversions. Fort Lee, VA, 2013, 3. 
Appendix 2. ASC Role in Global Logistics 2020 Concept.

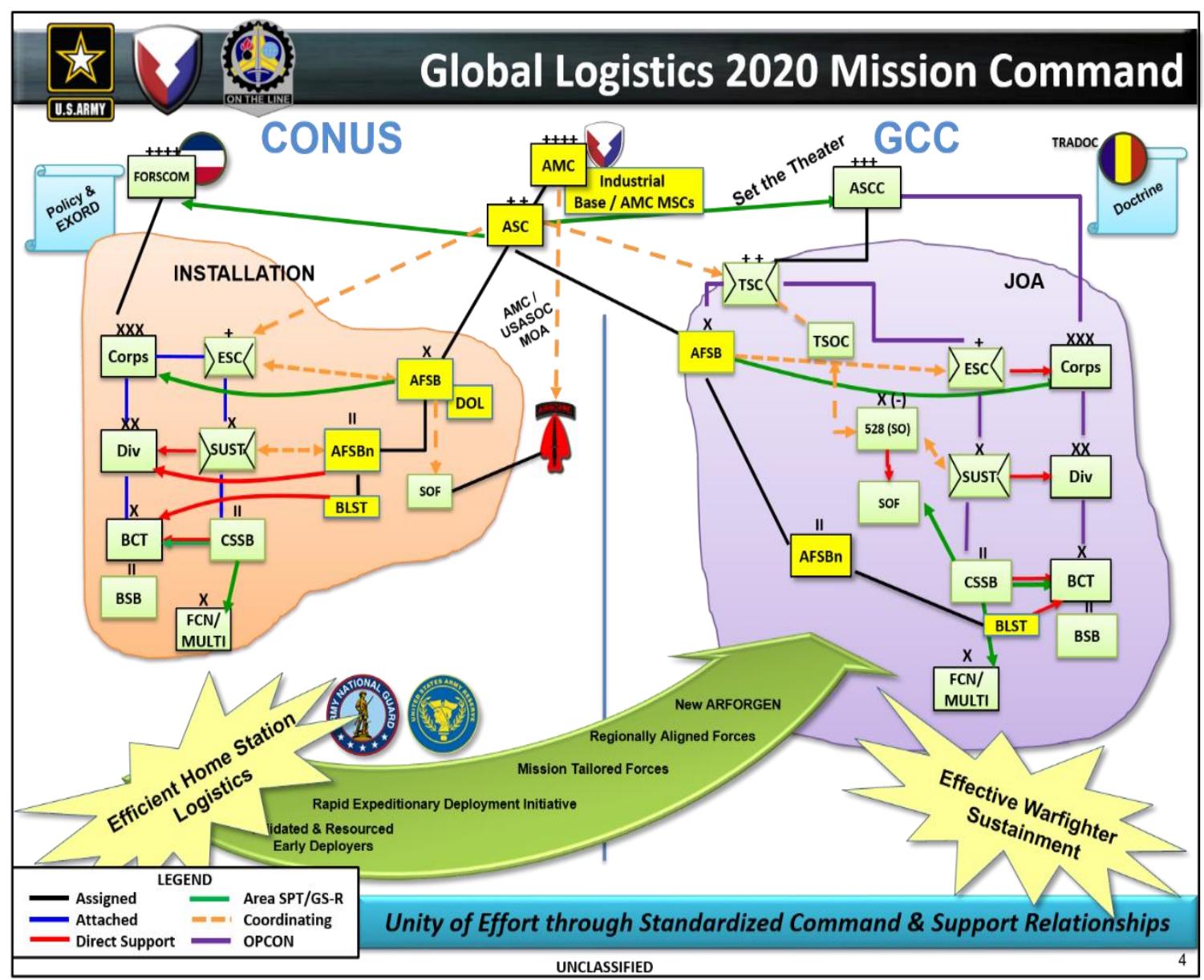

Source: Headquarters, Army Sustainment Command, United States Army. ASC and GL2020 MC Slides. Rock Island Arsenal, Rock Island, IL, January 14, 2013, 4. 
Appendix 3. Course of Action 1: Single Army Logistics Command.

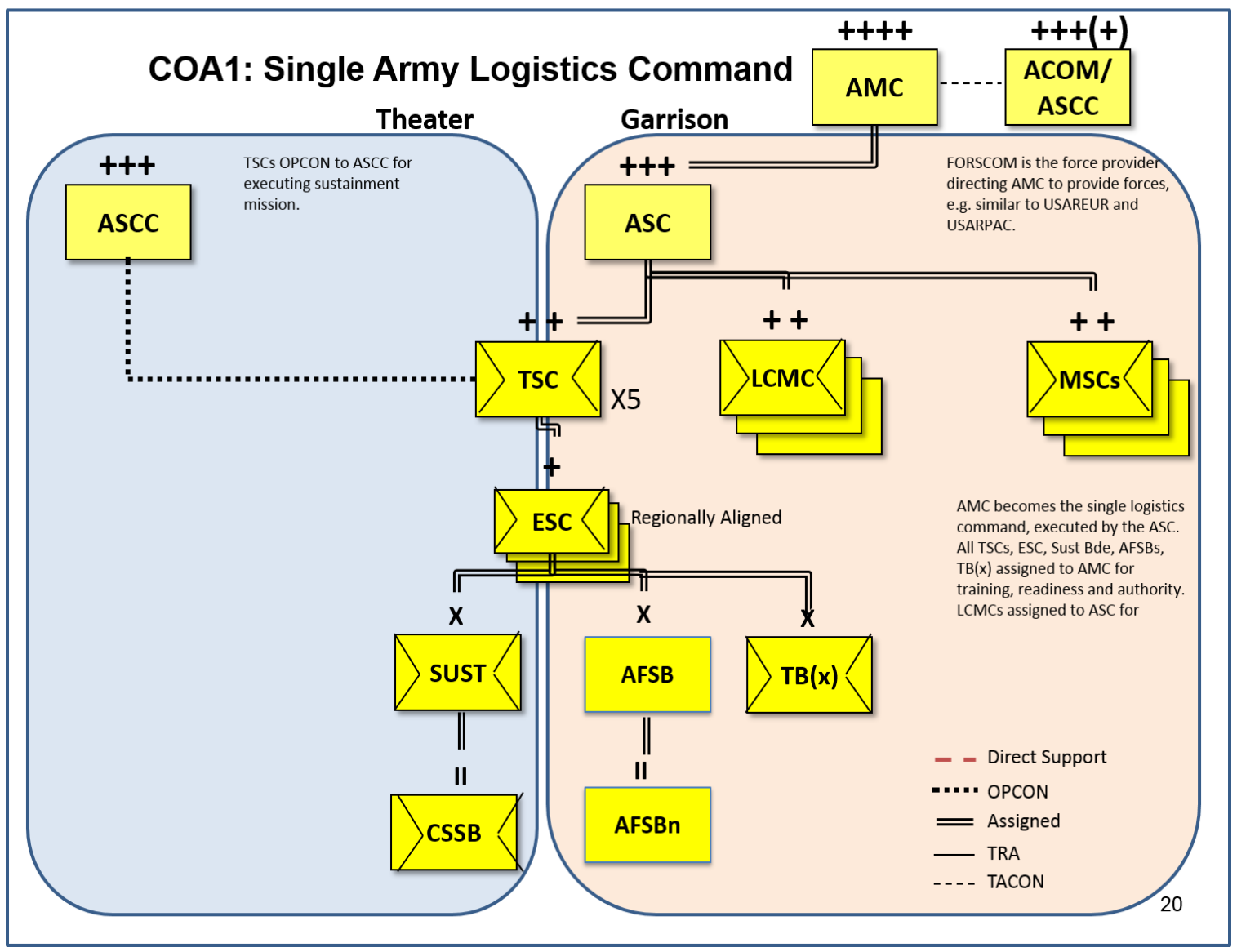

Source: Headquarters, Combined Arms Support Command, United States Army. "GLC Workshop \#2 Outbrief 1-2 Star GOSC," Global Logistics Concept Workshop. Fort Lee, VA, December 7, 2012, 20. 
Appendix 4. Original AMC Organization.

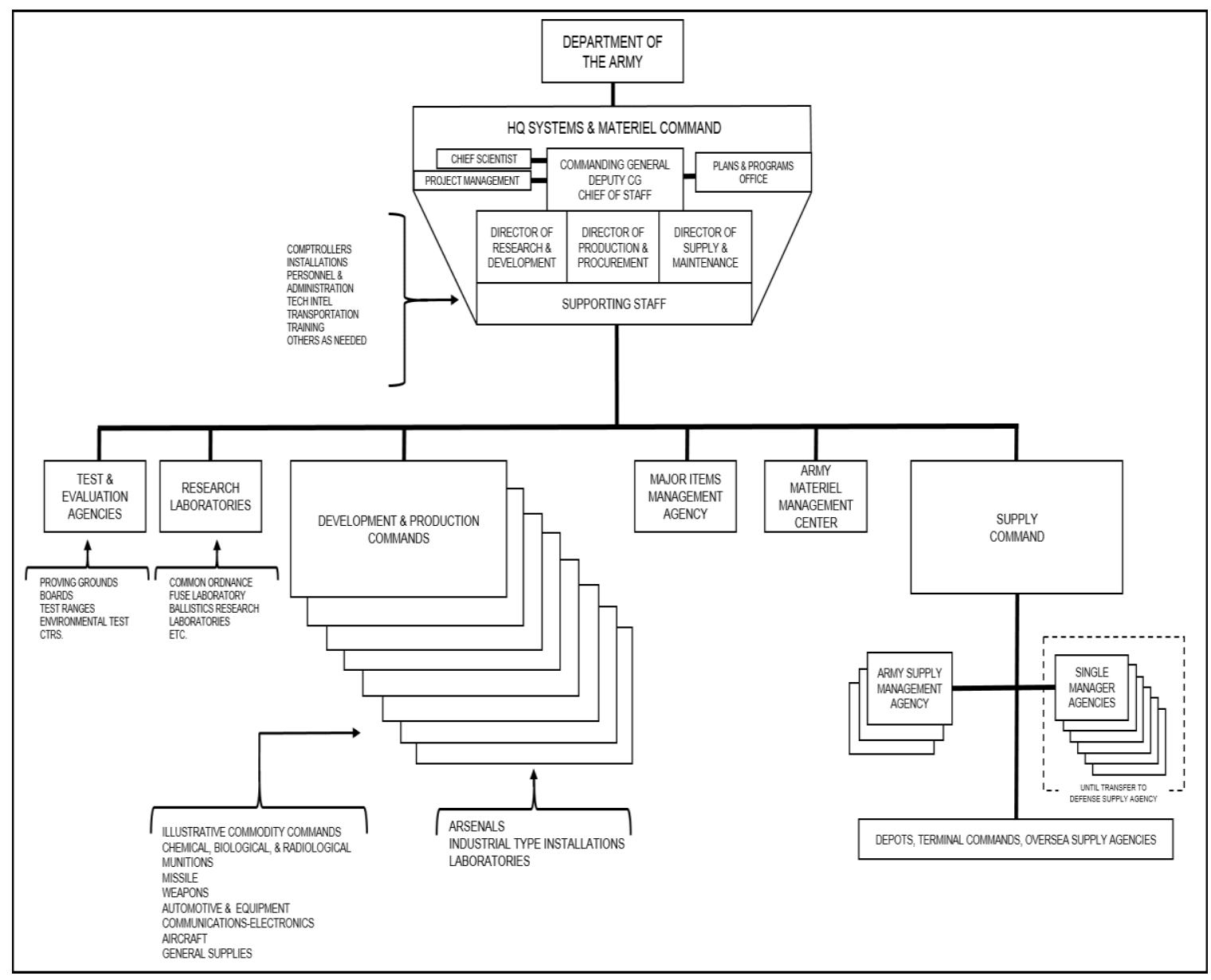

Source: James E. Hewes Jr. "Project 80: The Hoelscher Committee Report," From Root to McNamara Army Organization and Administration. Center of Military History, United States Army, Washington D.C., (1975). http://www.history.army.mil/books/root/chapter9.htm (accessed August 23, 2013), 335. 
Appendix 5. Timeline of Evolution to ASC.

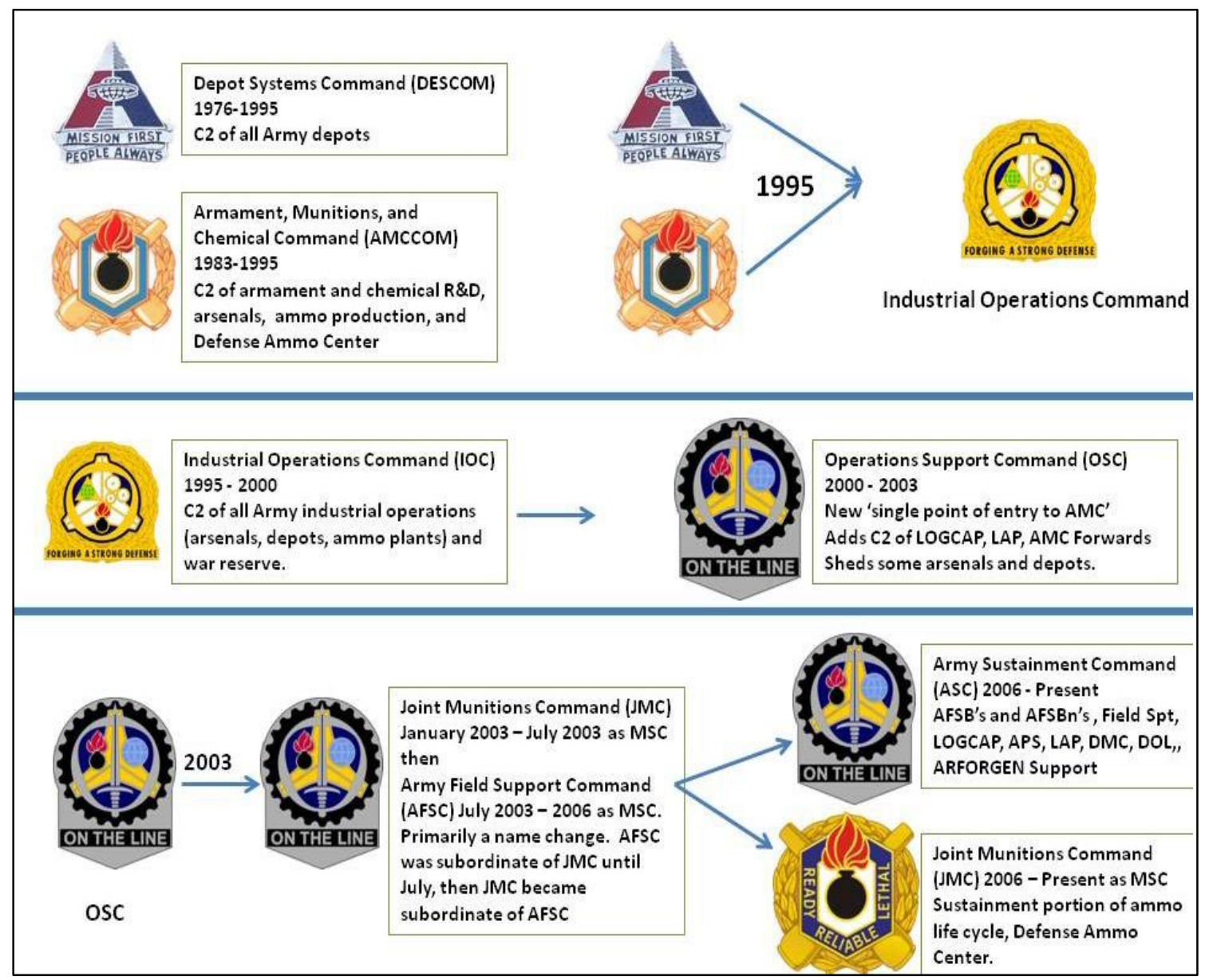

Source: Headquarters, Army Sustainment Command, United States Army. "Timeline of Evolution to ASC," The ASC History News Letter. Volume III, no. 3 (December 15, 2012). http://www.aschq.army.mil/ supportingdocs/HistoryNewsDec2012.pdf (accessed January 10, 2014). 
Appendix 6. AMC Worldwide Locations.

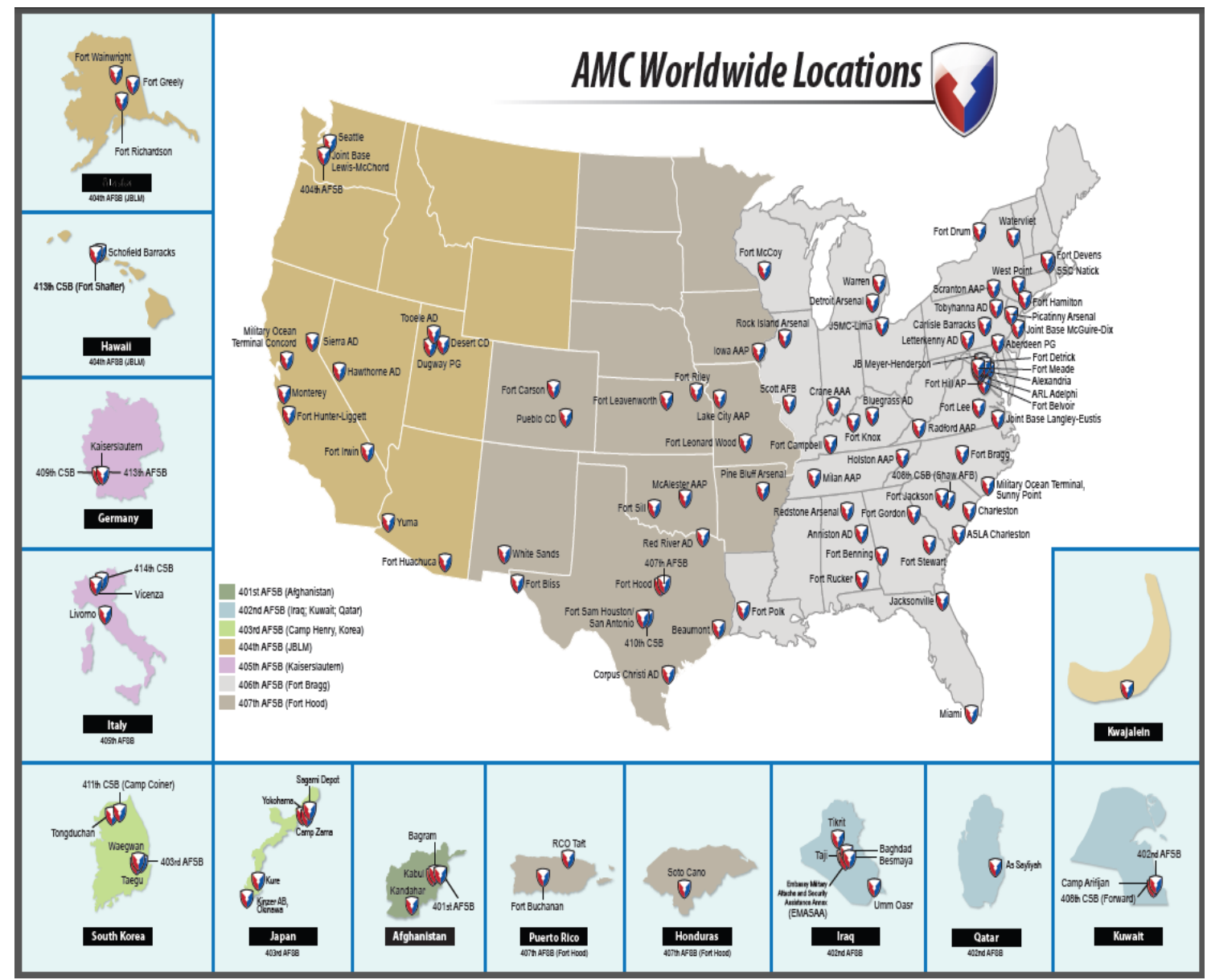

Source: Headquarters, Army Materiel Command, United States Army. "Locations," Army Materiel Command Organizational Structure. (January 1, 2014). http://www.amc.army.mil /amc/msc.html (accessed January 6, 2014). 
Appendix 7. Proposed Army Field Support Command (AFSC), later ASC, Headquarters Structure for Implementation in FY06, May 2003.

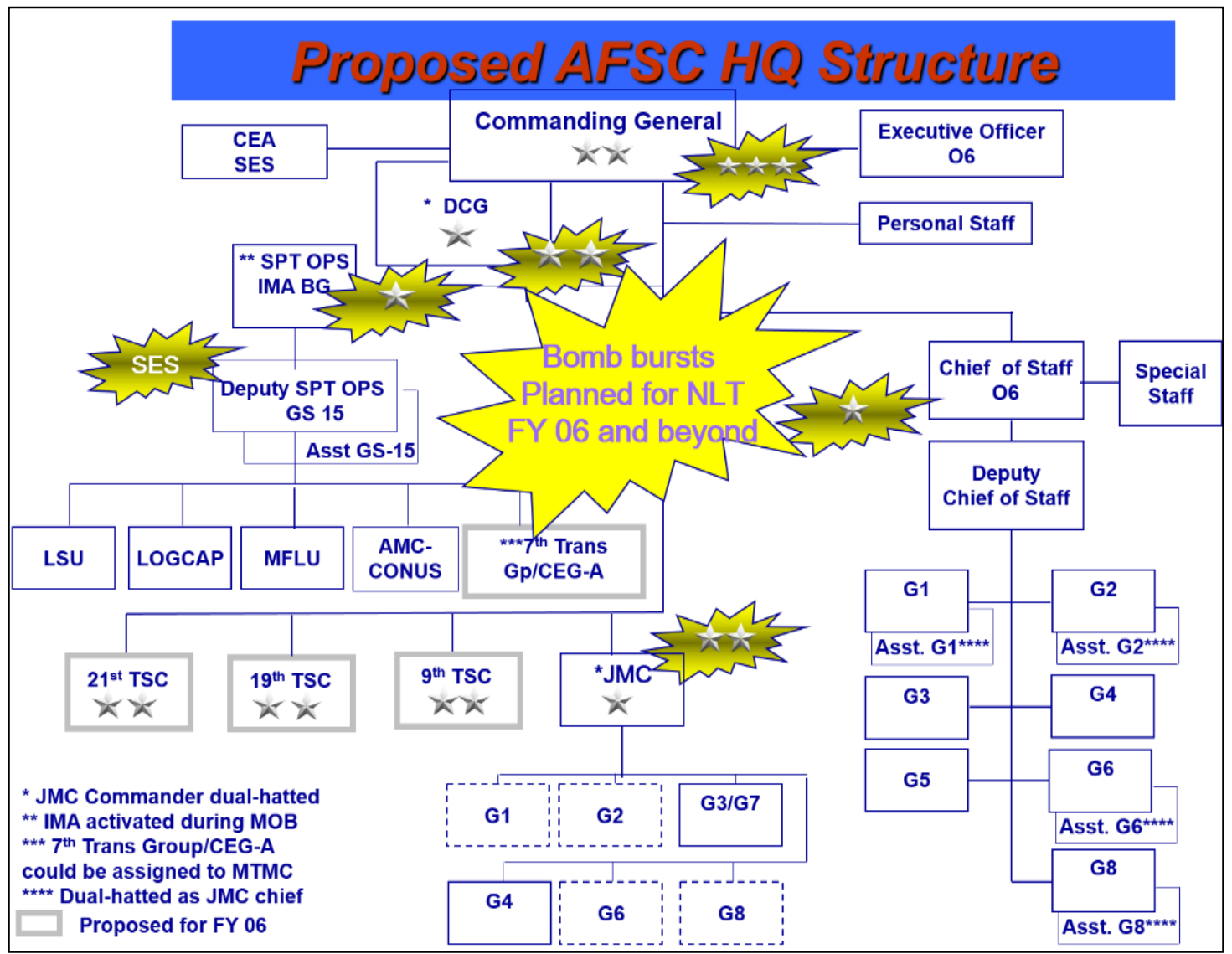

Source: McManus, Wade H. "Hamp". How Army Transformation Affects Us. Headquarters, U.S. Army Joint Munitions Command, Rock Island Arsenal, Rock Island, IL, May 2003, 12. 
Appendix 8. Joint Task Force-Haiti Logistics Organization, January 2010.

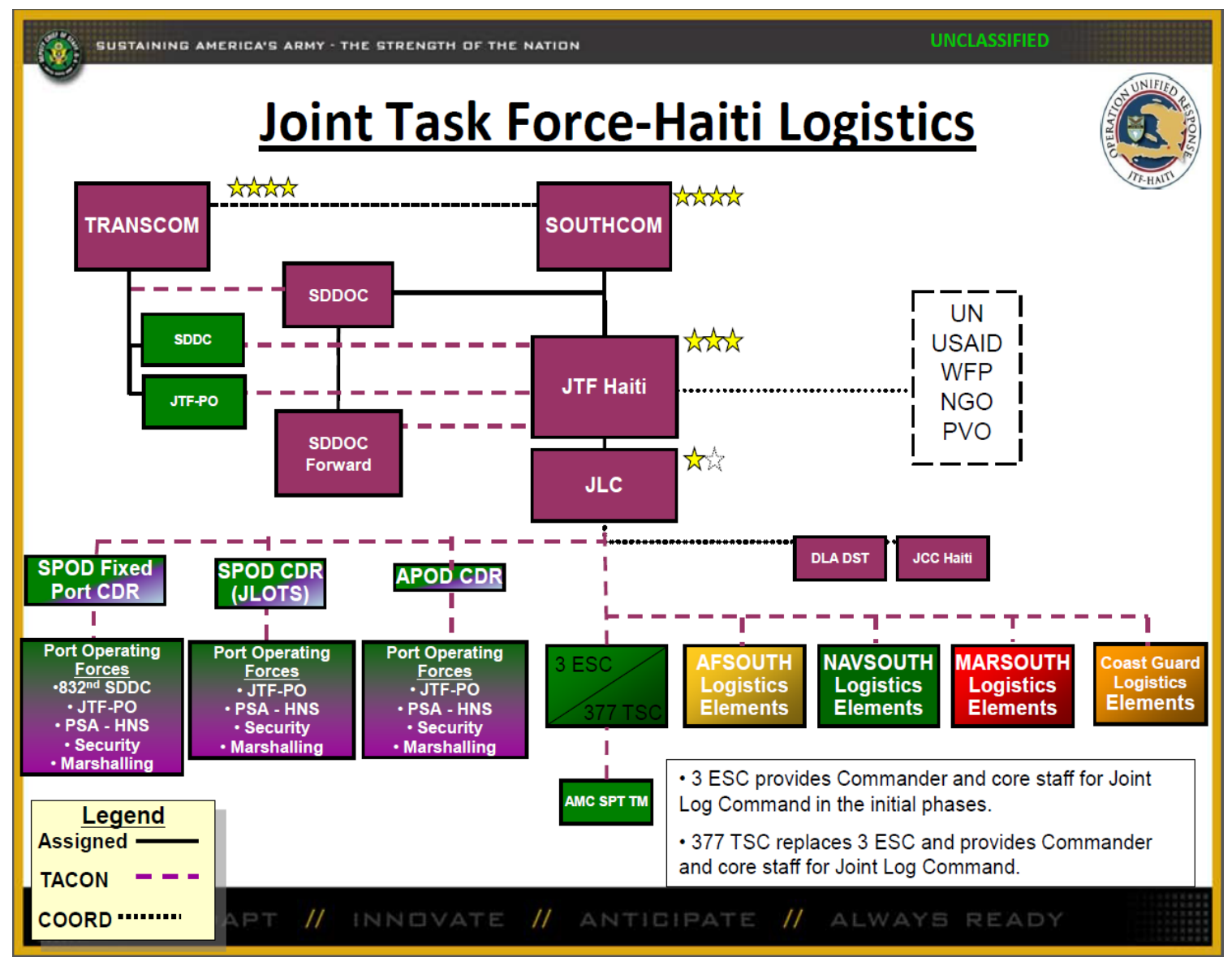

Source: Headquarters, Department of the Army. Theater Logistics CONOPS for Operation Unified Response: 17 June 2010, CASCOM Sustainment AAR. Washington D.C., June 2010, 3. 
Appendix 9. Leveraging Sustainment Operations in Continental United States (LSOC) Memorandum of Agreement between United States Forces Command and Army Materiel Command.

Source: Headquarters, Army Materiel Command and Headquarters, Army Forces Command, United States Army. "Leveraging Sustainment Organizations within the Continental United States," Memorandum of Agreement between United States Army Forces Command and Army Materiel Command. May 20, 2011.
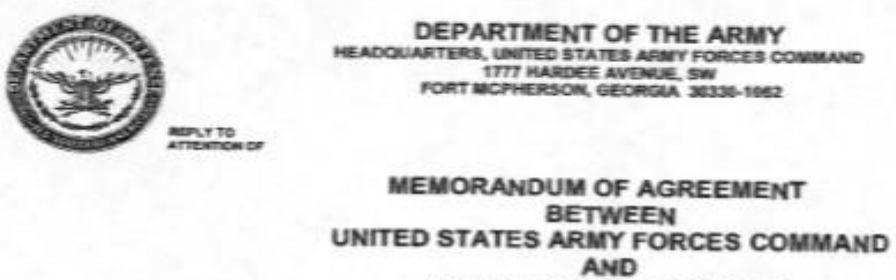

ARMY MATERIEL COMMAND

SUBJECT: Leveraging Sustainment Organizations in Continental United States (LSOC)

1. References:

a. Field Manual 3-0; Operations, February 2008

b. Field Manual 4-0; Sustainment, April 2009

c. Field Manual 4-94; Theater Sustainment Command, February 2010

d. Field Manual 5-0; The Operations Process, March 2010

e. Field Manual Interim 4-93,41; The Army Field Support Brigade Tactics, Techniques, and Procedures, December 2009

f. Commanding General, Forces Command Memorandum, subject: Leveraging Sustainment Organizations in Continental United States Terms of Reference, September 2010

2. This Memorandum of Agreement (MOA) prescribes the support relationship, roles and responsibilities for United States Amy Forces Command (FORSCOM) and Army Materiel Command (AMC) in the ongoing initiative of LSOC. This MOA sots the context for sustainment activitles in continental United States (CONUS) across all three levels of operations (from tactical to strategic). It provides a description of the roles of the key stakeholding agencies within this context. The intent is to bulid upon the already strong relationships between the Expeditionary Sustainment Commands (ESC), the Sustainment Brigades (SB), the Army Sustainment Command (ASC), and the Army Field Support Brigades (AFSB), all in support of the senior commander and his/her Army force generation (ARFORGEN) mission.

3. United States Army Forces Command/Readiness Core Enterprise is the supported command with AMCMateriel Enterprise (ME) as the supporting command. The ASC will provide lilaison to, and establish communication with, 
SUBJECT: Leveraging Sustainment Organizations in Continental United States

FORSCOM as required by AMC. The Executive Agents for execution of this memorandum are Commanding General (CG), ASC and FORSCOM G-4.

\section{New Roles and Responsibilities for FORSCOM:}

As defined in the LSOC, Terms of Reference, signed by CG, FORSCOM on 8 September 2010, the ESC commandor will be the senior operational logistician within the designated area of interest (AOI) when in CONUS. Expeditionary Sustainment Commands are authorized to advocate for and coordinate, mentor, and advise across the sustainment community within their respective AOls. (See Annex C).

\section{New Roles and Responsibilities for AMC:}

a. The ASC supports FORSCOM by providing distribution management across CONUS. In this capacity, ASC acts as the FORSCOM Distribution Management Center (DMC) with functional roles as outlined in Annex B. The ASC will utilize the Army's Logistics Information Warehouse to gain and maintain visibility and assist in the administration of the Army's materiel management system from the national sustainment base to the CONUS geographic theater. The ASC will plan, prepare, and execute operational-level logistics within the CONUS theater, while simultaneously supporting deployment, movement, sustainment, redeployment, Reset, and retrograde. As the senior operationallevel logistics headquarters in CONUS, ASC executes its CONUS mission through coordination with FORSCOM sustainment organizations in support of FORSCOM priorities. Commanding General, FORSCOM will specify the control and tasking authorities given to ASC in relation to DMC priorities performed in support of FORSCOM. Army Materiel Command will retain command and control (C2) for ASC and develop overall strategic priorities for ASC. In addition to materiel management, ASC is given the flexibility to coordinate with sustainment commanders and staff within FORSCOM through mentorship, individual professional development, and training advice. Training and readiness authority is, however, retained by the FORSCOM senior commanders as outlined in the FORSCOM C2 Execution Order. Commander-to-commander relationships across both enterprises are key and essential to the overall success of LSOC.

b. An AFSB can surge capabilities across the installation in order to support ARFORGEN requirements. The AFSB commander is the senior operational logistician for the ME in support of the senior commander. The AFSB may assume materiel management responsibilities when the ESC or SB headquarters deploys, execution of which will be accomplished by leveraging existing AMC and FORSCOM capabilities. Any capabilities or responsibilities being leveraged 
SUBJECT: Leveraging Sustainment Organizations in Continental United States

that are not budgeted under the current design will be discussed and resourced prior to mission assignment. This decision will be based upon analysis of mission and support requirements of the organizations remaining on the installation in support of the senior commander.

6. Direct liaison authorization is granted to ASC and its subordinate elements for sustainment information requirements and actions with CONUS ESCs, SBs and Combat Service Support Brigades as required to meet FORSCOM sustainment requirements. This authorization carries with it the requirement of keeping commanders informed at all levels. It does not imply an authority through which command may be exercised.

7. This MOA is effective upon the latest date of signature.

8. This MOA will be reviewed annually to ensure alignment with the most current operational environment and requirements of the senior commanders. It is subject to modification and/or change, as mutually agreed upon, by the signers or their designated representatives.

9. This MOA is subject to termination upon written notice by Commander, AMC or FORSCOM.
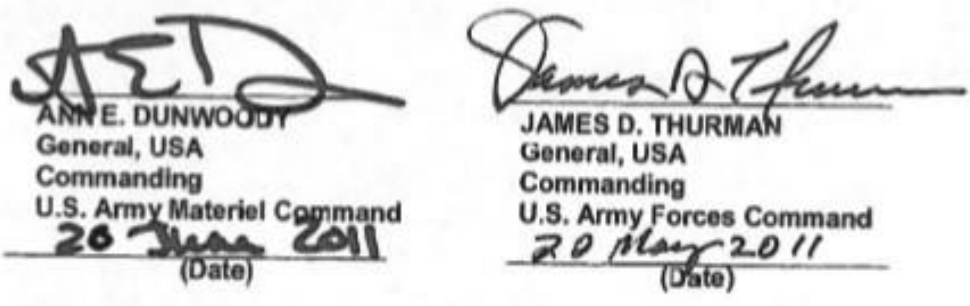
SUBJECT: Leveraging Sustainment Organizations in Continental United States (LSOC)

Annexes:

Annex A: Current Roles and Responsibilities of Forces Command and Army Materiel Command

Annex B: Sustainment Functions Provided by Army Sustainment Command

Annex C: Continental United States Area of Responsibility/Area of Interest Support Map

Annex D: Leveraging Sustainment Organizations in Continental United States Relationships 
SUBJECT: Leveraging Sustainment Organizations in Continental United States

\section{Annex A: Current Roles and Responsibilities}

1. Forces Command (FORSCOM)/Readiness Core Enterprise (Executive AgentG-4) current roles and responsibilities include:

a. The Expeditionary Sustainment Command (ESC) provides technical and functional supportloversight to sustainment brigades (SB). The ESC assists the FORSCOM commander with the sourcing and management of sustainment echelons above brigade units. The ESC coordinates active duty sourcing requirements with the SB commanders and provides the best sourcing recommendations while assisting the FORSCOM commander with the tactical and functional training of SBs (Active and Reserve Component units) in support of FORSCOM's Army force generation (ARFORGEN) cycle.

b. The sBs are attached to senior commander for full administrative control. They also provide training readiness authority to all functional subordinate units as well as tactical-level sustainment on their respective installations. They plan and execute materiel management and distribution guidance from the ESCs and coordinate with Army Sustainment Command (ASC)ESC materiel managers for asset management, visibility, and distribution to support divisions, brigades, or other units on their assigned installation. The SB commander, when not deployed andlor co-located with an ESC headquarters, is the senior operational logistician on the installation.

c. The Mission Support Elements (MSE) coordinate and assist in the synchronization of sustainment operations across their respective installations. The MSE is a Generating Force Table of Distribution and Allowances organization assigned to FORSCOM and attached to the designated FORSCOM commander that serves as senior commander having Administrative Controi/Title 10 responsibilities. The MSEs provide direct support to the senior commander in the execution of executive type and Administrative Control/Title 10 functions. The MSE provides area support to all assigned, attached, and tenant FORSCOM units in the commander's area of responsibility.

3. Army Materiel Command/Materiel Enterprise (Executive Agent-U.S. Army Sustainment Command) current roles and responsibilitios include:

a. Army Sustainment Command plans, prepares, and executes operationallevel logistics operations within continental United States and is capable of planning, controlling, and symchronizing operational-level Amy sustainment for the FORSCOM commander. It provides a centralized logistics command and control structure, simultaneously supporting deployment, movement, field-level 
SUBJECT: Leveraging Sustainment Organizations in Continental United States

sustainment, redeployment, reconstitution, and retrograde. Army Sustainment Command provides materiel management to meet the sustainment readiness requirements of the ARFORGEN process. This includes support for Left-Behind Equipment, management of Pre-deployment Training Equipment, and Field-level Reset operations.

b. The Army Field Support Brigade (AFSB) executes Materiel Core Enterprise functions for ASC and provides integrated and synchronized acquisition, logistics and technology support in its area of responsibility. Its missions include Logistics Civilian Augmentation Program, Reset, Left-Behind Equipment, Pre-deployment Training Equipment, Logistics Assistance Program, Army Prepositioned Stocks and integrating and implementing the Directorate of Logistic realignment to ASC. The AFSBs are also responsible for Life Cycle Management as well as the Army Oll Analysis Program. Furthermore, the Army Field Support Brigades coordinate between units and the Research, Development and Engineering Command, Army Test and Evaluations Command, and Program Executive Offices. In addition to performing their AMC roles, AFSBs provide support to the SBs when co-located on the same installation. 
SUBJECT: Loveraging Sustainment Organizations in Continental United States

Annex B: Sustainment Functions Provided by Army Sustainment Command (ASC)

1. In coordination with Forces Command (FORSCOM) G-4, Army Sustainment Command (ASC) translates the FORSCOM commander's operational priorities into priorities of continental United States sustainment support.

2. In coordination with FORSCOM G-4, ASC develops the continental United States concept of support.

3. Army Sustainment Command establishes strategic and joint interfaces to facilitate synchronization and integration efforts in support of the FORSCOM commander's priorities.

4. Army Sustainment Command monitors continental United States operational readiness for FORSCOM units.

5. Army Sustainment Command verifies sustainment requirements for support of FORSCOM units.

6. Army Sustainment Command develops, coordinates, and monitors plans, policies, procedures, and programs for supply, transportation, maintenance, and field services in support of FORSCOM operational requirements.

7. Army Sustainment Command coordinates and supervises implementing policies and directives relative to supporting current and future FORSCOM operational requirements.

8. Army Sustainment Command monitors AMC-controlled logistics resources and provides recommendations for cross-leveling of logistics resources for mission support, as required.

9. Army Sustainment Command monitors status of Army-owned continental United States operational and tactical level stocks.

10. Army Sustainment Command utilizes all possible existing means of automation to establish and maintain a logistics common operating picture.

11. Army Sustainment Command maximizes strategic, operational, and tactical reach through close coordination with AMC, FORSCON G-4, and continental United States ESCs. 
SUBJECT: Leveraging Sustainment Organizations in Continental United States

12. Army Sustainment Command maximizes FORSCOM materiel readiness through the effective use of maintenance resources.

13. Army Sustainment Command monitors all facets of transportation, to include air, land, and sea transportation assets, supporting FORSCOM operational requirements.

14. Army Sustainment Command monitors the in-transit visibility system and provides in-transit visibility data as required by FORSCOM.

15. Army Sustainment Command provides materiel management in support of continental United States FORSCOM operational requirements.

16. Army Sustainment Command coordinates and monitors continental United States contracting support requirements in support of FORSCOM operational requirements. 
SUBJECT: Leveraging Sustainment Organizations in Continental United States

Annex C: Continantal United States Area of Rosponsibility/Area of Interest

Support Map

CONUS Area of Responsibility/Area of Interest Support Map

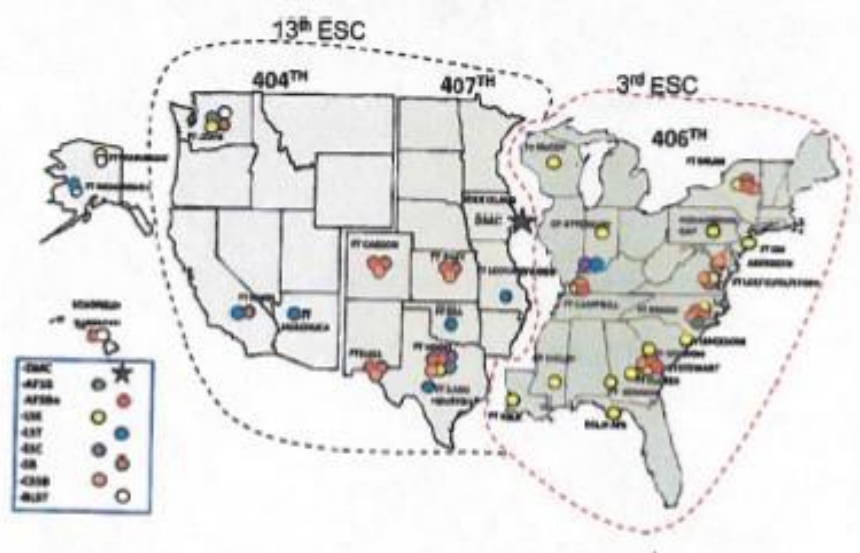

a 